Portland State University

PDXScholar

1989

\title{
John Humphrey Noyes, 1811-1840 : a social biography
}

Susan Adams DuBay

Portland State University

Follow this and additional works at: https://pdxscholar.library.pdx.edu/open_access_etds

Part of the Social History Commons, and the United States History Commons Let us know how access to this document benefits you.

\section{Recommended Citation}

DuBay, Susan Adams, "John Humphrey Noyes, 1811-1840 : a social biography" (1989). Dissertations and Theses. Paper 3568.

https://doi.org/10.15760/etd.5452

This Thesis is brought to you for free and open access. It has been accepted for inclusion in Dissertations and Theses by an authorized administrator of PDXScholar. Please contact us if we can make this document more accessible: pdxscholar@pdx.edu. 
AN ABSTRACT OF THE THESIS OF Susan Adams DuBay for the Master of Arts in History presented June 30, 1989.

Title: John Humphrey Noyes, 1811-1840: A Social Biography

APPROVED BY MEMBERS OF THE THESIS COMMITTEE:

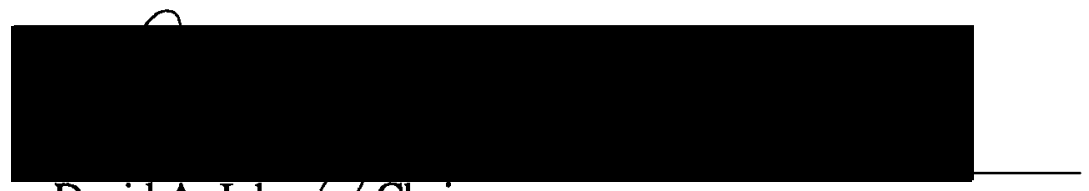

David A. Johnson, Chair

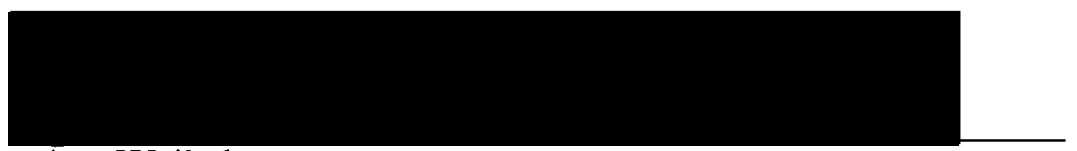

\section{Ann Weikel}

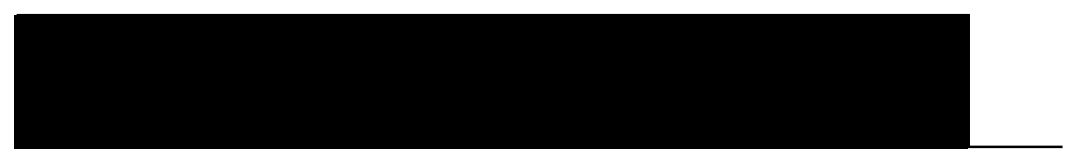

Thomas D. Morris

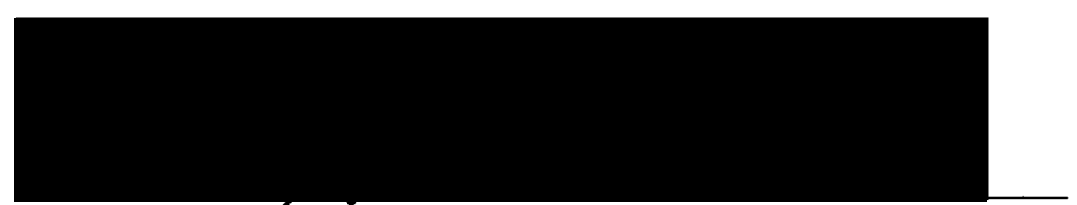

Michael A. Hólister

John Humphrey Noyes was the founder of the Oneida Community, one of the most successful utopian ventures in nineteenth-century America. Early in his life, Noyes was a deep religious thinker, but he founded Oneida as an ideal society based on extending the family unit, and not as a church. Noyes's social theories eventually overwhelmed his former religious concentration. 
The purpose of this thesis is to locate in Noyes's religiously-oriented youth the sources of his social interests. Few scholars have studied in depth the childhood and young manhood of John Humphrey Noyes, but that is where the roots of his social theories are to be found. Noyes did write his religious autobiography, but completely passed over his formative years. Further, he never wrote the analysis of his social ideas and experiences that he had once promised. However, many of his early letters and journals have been compiled and edited by his relatives; and his immediate family left reminiscences of his youth. These works provide most of the available information on the childhood of Noyes. Large gaps in his history do exist, however. Therefore, the modern psychological theories of Erik Erikson are used to illuminate the otherwise shadowy areas of Noyes's early life.

The key to Noyes's character is control. As a young boy in a prosperous Yankee family and later at school, college, and divinity school, Noyes tried constantly to combat the disorder he saw everywhere around him. He desired to exert control over himself, first of all, and then over his family and his social environment. His interpretation of the Second Coming of Christ (which he believed to have already occurred) fulfilled his need for self-control in his religious life, by obviating his subservience to his previous, oppressive Congregational upbringing. He was thus relieved of much psychological torment and enabled to embark on his social experiments. Noyes's adoption of religious Perfectionism freed him from a desire to save souls, and allowed him instead to concentrate on establishing the perfect society for those already saved. The basis of his new society was Complex Marriage, a hierarchical form of group marriage among his followers, with himself as its leader and patriarch. In Noyes's eyes, Complex Marriage reestablished in a most radical form the 
patriarchal family structure that he believed God had ordained and that he felt he had lacked in his youth.

The study of the youth of John Humphrey Noyes shows the roots of a leader more interested in society than in theology. Further, his early social experiences-at home, in school and college, in business, with the Antislavery and Temperance causes, with Revivalism, and especially in his relationships with the women in his life-exemplify many of the general tendencies in America before the Civil War. As the founder of a utopian community that practiced radical forms of sexuality and economics, Noyes's views on the important issues of his time did not often accord with mainstream American society. Nevertheless, he touched or was influenced by so many of the vital elements of antebellum society and culture that a study of Noyes can be a valuable pathway to an understanding of the history of that time. 
JOHN HUMPHREY NOYES, 1811-1840

A SOCIAL BIOGRAPHY

by

SUSAN ADAMS DUBAY

A thesis submitted in partial fulfillment of the requirements for the degree of

\section{MASTER OF ARTS \\ in \\ HISTORY}

Portland State University

1989 
TO THE OFFICE OF GRADUATE STUDIES:

The members of the Committee approve the thesis of Susan Adams DuBay presented June 30, 1989.

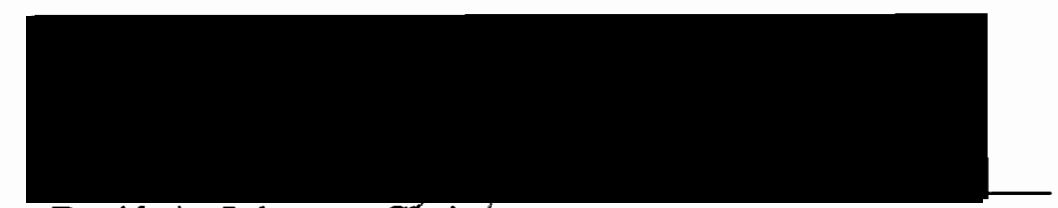

David A. Johnson, Chair/

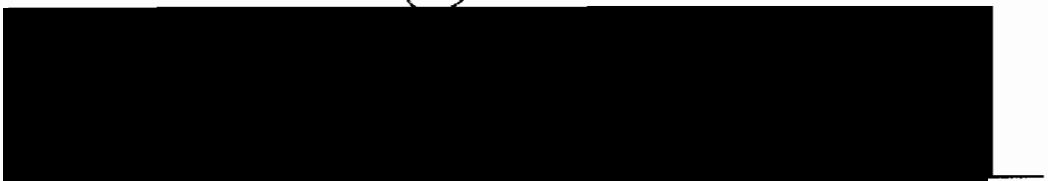

Ann Weikel

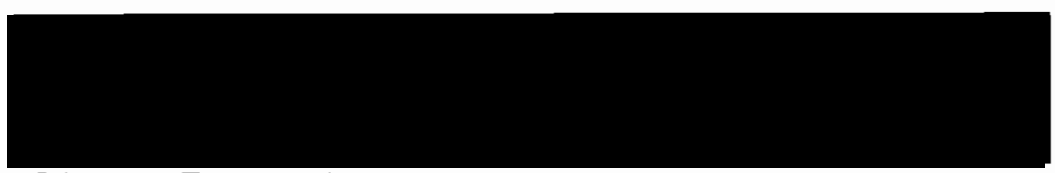

Thomas D. Morris

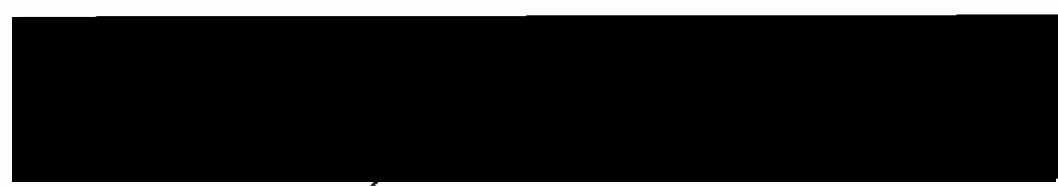

Michael A. Hollister

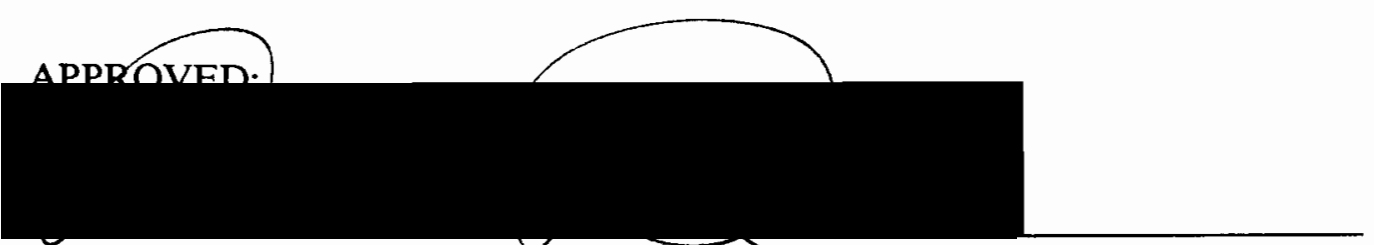

Bernard V. Burke, Chair, Department of Histery

C. William Savery, Interim Vice Provost for Gadyate Studies and Research 


\section{ACKNOWLEDGEMENTS}

It is not possible to give due credit to all those professors, fellow students, and friends who helped bring this thesis to fruition. But I must single out those whose contribution was so significant that this thesis, in form and content, would not otherwise have seen the light of day. First, and foremost, I would like to thank my teacher and advisor, Professor David A. Johnson. I am grateful for his profound knowledge of nineteenth-century America, for his confidence in this project, for his superior editorial skills, and especially for his unstinting encouragement.

I would also like to acknowledge the benefit I derived from the other members of my thesis committee, Professors Ann Weikel, Thomas Morris, and Michael Hollister. Their comments were cogent and much to the point, helping to restrain this work from the excesses of overstatement and lack of clarity. I also appreciate the encouragement of Professor Susan Karant-Nunn in an early stage of this project.

It should go without saying, however, that while my academic advisors are due credit for much of the good in this thesis, I alone take the responsibility for any errors it may contain.

Finally, I must acknowledge the true source of my inspiration while pursuing my academic career, my family. I am grateful to my daughter, Emily, for her reliability; to my daughter, Eleanor, for giving me the idea ("out of the mouth of babes"); and to my husband, Tom, for making all things possible. 


\section{TABLE OF CONTENTS}

PAGE

ACKNOWLEDGEMENTS

\section{CHAPTER}

I INTRODUCTION $\ldots \ldots \ldots \ldots \ldots \ldots \ldots \ldots \ldots \ldots \ldots$

II $\quad$ FAMILY $\ldots \ldots \ldots \ldots \ldots \ldots \ldots \ldots \ldots \ldots \ldots \ldots$

III $\quad$ EDUCATION $\ldots \ldots \ldots \ldots \ldots \ldots \ldots \ldots \ldots \ldots \ldots \ldots$

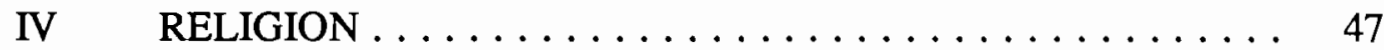

V SOCIAL PERFECTION $\ldots \ldots \ldots \ldots \ldots \ldots \ldots \ldots \ldots$

VI CONCLUSION $\ldots \ldots \ldots \ldots \ldots \ldots \ldots \ldots \ldots \ldots \ldots \ldots$

NOTES . . . . . . . . . . . . . . . . . . . . . . . . . . . . 99

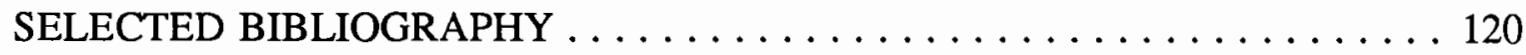




\section{CHAPTER I}

\section{INTRODUCTION}

"Whoever has had the opportunity of acquaintance with society in New England, during the last twenty-five years," wrote Ralph Waldo Emerson in 1844, ". . . will have been struck with the great activity of thought and experimenting." Emerson noted that everywhere were signs of "sincere protesting against existing evils," which led to a "keener scrutiny of institutions and domestic life than any we had known." In particular, Emerson commented on the many social reformers who relied on "Association" to achieve their goals. These reformers seemed to be daily creating new communities which would exemplify their idea of the perfect society. Emerson already counted three in Massachusetts and "many more in the country at large." "They aim." he wrote, "to give every member a share in the manual labor, to give an equal reward to labor and to talent, and to unite a liberal culture with an education to labor." But, while he hailed these associations as "composed of men and women of superior talents and sentiments," Emerson could not abandon his traditional belief in individual, as opposed to communal, regeneration. ${ }^{1}$

Emerson's essay, however, does point out the importance of the communitarian movement in the social ferment of nineteenth-century America. With the optimism that was common in the first half of that century, men did believe that they could point the way to social reform by establishing ideal communities. Most of these efforts, however, were ephemeral, foundering after only a few months due to lack 
of capital, expertise, and simple common sense. One community, however, was, by the standards of other utopian communities, an almost unqualified success for thirty years. That was the Oneida Community, founded in upstate New York in 1847 by John Humphrey Noyes. Oneida, itself, as a rare success among these ideal societies (along with the Shakers and the Mormons), has been the subject of much study by students of the nineteenth century. Not only did it exhibit an unusually profitable economic system in a communistic society, but it founded its social structure on a theory of group marriage that was totally alien to its temporal context. Noyes, as the founder and sole leader of this unique community, has likewise attracted the interest of scholars; in fact, he invited it.

Noyes believed that the evils in society arose from selfishness and exclusive possession, not only of goods, but of persons. He spent most of his adult life trying to publicize this idea and to convince the American public that communism of goods and spouses was biblically mandated. In 1849 , Noyes pulled together all the religious journeys which had led him to found his community, in a religious autobiography, which he entitled Confessions of John H. Noyes, Part I. Confession of Religious Experience. Noyes intended this "most valuable kind of history" to satisfy the curiosity of anyone interested in his career as an "editor and author." He also wanted this work to be a preliminary to "subsequent confessions of social experience and social principles."2

Noyes succeeded in his first aim. After giving short shrift to his childhood experience, he launched into a detailed and introspective account of his religious journey from college to leadership in the Perfectionist movement. His second goal. however, was never realized. He never wrote Pan II-the social side-of his Confession. 
To fill in this gap in Noyes's life history will be the purpose of my thesis. I will reconstruct the social biography of John Humphrey Noyes in order to study the development and evolution of his social theories and institutions. It is my contention that Noyes was much more a social thinker and activist than a religious leader. $\mathrm{He}$ never formally renounced any of his early religious beliefs; instead, his religious orientation waned while his social interests took precedence, especially after 1840 . He always envisioned his life's work-epitomized in the Oneida Community-as "the enlargement of the home, . . the extension of the family union," and definitely not as a church. ${ }^{3}$ While his vocabulary and writing style were firmly rooted in his intense biblical studies, the content of his message was primarily social. It is important, therefore, to discover what Noyes saw when he looked at the society around him in his formative years, in childhood, and later in college. What, to him, was good, and what needed rehabilitation and revitalization in order to have a place in the Kingdom of God?

Noyes's lifelong goal can be narrowed to one concept, the need for control, on both societal and personal levels. He was born in 1811 into a nation just beginning to undergo immense social, economic, and political changes. Everywhere around him, Noyes saw society in a state of flux. No firm boundaries seemed to remain to any traditional institution. Churches were undergoing frenzied revivals; the traditional family structure was being undermined by the new industrial economy; courtship and marriage lost its firm anchor of parental control and degenerated into romantic emotionalism; the schools sheltered uncontrollable, rambunctious youth; the rising market economy rewarded selfish individualism and greed. 
John Humphrey Noyes had no tolerance for this disorder, and he always feared overt emotionalism. Contemporary revivalism, romantic love, and market relations appalled him, but for personal reasons he was helpless to effect even the smallest change in his surroundings. For Noyes, during his first thirty years, was unable to take control of himself. In psychological terms, he was unable to establish a personal identity. He could not separate himself psychologically from his family. He suffered agonies of shame and doubt over his relationship to God and to society. But the crisis that most devastated him was his inability to find a career that would make him independent, both financially and psychically from his family, a career that would imbue him with the qualities of manhood.

By the end of the 1830s, however, Noyes had triumphed over all this adversity. He did indeed reach manhood. By confronting and controlling just those things he most feared-revivalism, emotion, romantic love, and his family-Noyes transformed himself into a powerful social thinker, a charismatic leader who was able to bring his most radical ideas to full fruition in a society which he totally controlled.

My thesis will concentrate on this rather neglected period of Noyes's life.

Noyes has always been a popular subject for historians of the nineteenth century, primarily because of the great economic and social success of Oneida. But most writers, including many members of Noyes's own family, are not very forthcoming about Noyes's family and early life. Because the Oneida Community is usually their ultimate concern, Noyes's social theories are treated in their final, fully-formed manifestations, without consideration of their roots or historical development. Few writers relate these ideas to Noyes's youth, his schooling, his family life, or his upbringing in turbulent Vermont. This is true of even the most valuable source on the family history of 
Noyes, his nephew George Wallingford Noyes's Religious Experience of John Humphrey Noyes, Founder of the Oneida Community and John Humphrey Noyes: The Putney

Community. Modern scholars agree that these biographical works are reliable despite editor Noyes's "condensing and rearranging." ${ }^{-4}$ They are based almost exclusively on John Humphrey Noyes's manuscript diaries and letters (now lost). ${ }^{5}$ But their purpose, to form a coherent history of Perfectionism, Putney, and Oneida, indicates their limitations. ${ }^{6}$ Concentrating on Noyes's adult accomplishments, these works offer only brief, glancing glimpses into Noyes's social background and development.

The only full-scale biography of Noyes is Robert Allerton Parker's $A$ Yankee Saint: John Humphrey Noyes and the Oneida Community, written in 1935. Parker explains Noyes's greatness in religious and economic terms. He sees Noyes as successful only when he abandons his rigid Perfectionism in favor of Yankee practicality. Parker's sources include both G. W. Noyes and other of John Humphrey Noyes's sons and daughters, but this biography is marred for the modern student by its lack of source citations. ${ }^{7}$

The most intensive study of Noyes's personal growth from childhood on was done by Robert David Thomas in 1977. The Man Who Would Be Perfect: John Humphrey Noyes and the Utopian Impulse is a psycho-biography that, while provocative and revealing, reduces Noyes's complex personality to a diagnosis of narcissism. This work is valuable, however, for the stress it places on the youth, family, and education in the formation of Noyes's adult personality.

My thesis relies heavily on the main point of Thomas's work, that Noyes's psychological development in childhood and youth is crucial to understanding his later career. Even more, Noyes's severe identity crisis proved to be the very wellspring of 
his future creativity. Although admittedly an anachronistic tool, the use of modern psychology is singularly appropriate in the case of John Humphrey Noyes. Throughout his life, Noyes acknowledged the unconscious sources of his actions. Especially in his early years, he identified the irrational nature of his motivations as either religious inspiration or the results of madness. Modern students are not describing any different phenomena in his life than Noyes did; they simply attach different labels.

Here this thesis parts company with Thomas. To my mind, a reductionist concept such as narcissism does not adequately illuminate the mind of Noyes and does not account for his remarkable success in later life. My interpretive framework is based instead on the work of Erik Erikson, specifically his theory of the development of the adult identity contained in his "Eight Stages of Man," in his book Childhood and Society, and his notion of the "moratorium," a period in young adulthood when new, independent ideas struggle to overcome old, socially-imposed beliefs, explained in his Young Man Luther. Based on Erikson's experience as a clinical psychologist, both the "Eight Stages" of the development of an adult self-identity and the "moratorium" fit extremely well with the facts of Noyes's life: neither the tools nor the biography have to be bent in any way to accommodate each other. Further, there is a real need for some explanatory device to fill in the gaps in the knowledge of Noyes's childhood. Since Erikson's models fit the known facts so well, they can also be relied upon to shed light on the more poorly documented events.

Besides narrating Noyes's personal journey, my thesis will focus on his relationship to his own times. I believe that the work of John Humphrey Noyes acts like a prism to nineteenth-century social history, at least that of the industrialized North. By studying his life it is possible to untangle the threads of his social 
environment. This is what Noyes himself did, extracting the discreet components of society from the confused disorder he perceived everywhere, propounding logical solutions to the problems, and using the reformed institutions as building blocks of a radical new society. Noyes, himself, thus becomes an excellent vehicle for studying the many tensions and anxieties of industrializing nineteenth-century society.

Noyes methodically considered, but discarded as panaceas or useless half measures, the many reform movements that his contemporaries had established to cure social evils. His solution was to break up the society, reform it, and start again from scratch. A vital work for understanding this aspect of Noyes`s work is Michael Fellman's The Unbounded Frame: Freedom and Community in Nineteenth Century American Utopianism. Fellman holds that Noyes, like other utopian reformers, believed in a final discoverable truth that could unite the fragmented society, put formal boundaries to the unsettling social fluctuations, and replace doubt and confusion with absolute certainty. Noyes not only accomplished this on a social level, he did it in his own life. Fellman notes that, above all, "Noyes was a rule-breaker toward all social conventions and a rule-maker in relationship to his followers." ${ }^{8}$ Noyes was able to act out this drama on the public stage only because he had already done so in his own life.

Relying on these basic ideas and works as its foundation, my thesis considers the following specific topics. Chapter II concerns the childhood and early family life of Noyes in the light of the changing status of the family in the early nincteenth century. It also explores the region in Vermont's Connecticut River Valley, where the Noyes family lived amid intermittent fears of social upheaval. The nineteenth century clashed strongly with the eighteenth in Vermont, causing a "social ferment" which profoundly 
affected the Noyes family and helped shape John Humphrey's social theories. The most important source in this regard is the work of G. W. Noyes (cited above), especially his compilation of the recollections and memoirs-primarily of a religious nature-of Noyes and his family. Secondary studies of the family in nineteenth century America are abundant. Relevant sources include works by Carroll Smith Rosenberg on women and Joseph Kett, Lois Banner, and John Demos on youth and adolescence. Vermont society is best studied in the pioneering work of David Ludlum, Social Ferment in Vermont, 1791-1850. Ludlum's work is expanded and focused more exactly on the Noyes's own section of Vermont by Randolph A. Roth's The Democratic Dilemma: Religion, Reform, and the Social Order in the Connecticut River Valley of Vermont, 1791-1850. This 1987 work employs statistical methods to analyze Vermont's social turmoil.

Although John Humphrey Noyes and his family had powerful holds on each other, he was happy to try life on his own in college. He was a brilliant student and his educational experiences were pivotal in his subsequent career. During college he changed career plans three times and suffered frequent and acute anxictics. Nevertheless, he prospered intellectually at Dartmouth, Andover, and Yale, and in his Confession he described his life at these schools more fully than any other aspect of his youth. Noyes's experiences at these schools is considered from a psychoanalytic viewpoint in Thomas's The Man Who Would Be Perfect. Most other writers treat only the religious aspect of Noyes's education (granted, he was a divinity student). However, these schools were undergoing revolutionary social transformations at that time, a subject explored by David F. Allmendinger in Paupers and Scholars: The Transformation of Student Life in Nineteenth-Century New England. Noyes 
acknowledged these changes, but tried to steer clear of them. He was an intense student, often a "loner," but, considering the emphasis he placed on liberal, secular education at Oneida, he must have been deeply influenced by his own college experiences. Noyes's educational experiences, then, are the subject of Chapter III. Chapter IV deals with Noyes's two religious conversions-the first at an evangelical revival and the second to radical Perfectionism-and his traumatic reaction to them. In his early twenties, Noyes was in a stage of his life where he thought and acted almost exclusively from a theological point-of-view. As shown in his autobiographical Confession, he was troubled by the social turbulence he saw around him. but until he had undergone his two conversions he was not able to consider any practical solutions to society's problems. His devastating psychological reaction to his conversions taught Noyes the importance of breaking both religious and social rules, and gave him the freedom to build from the ground up a more perfect society. Besides Noyes's own Confession, G. W. Noyes, in The Religious Experience of John Humphrey Noyes, Founder of the Oneida Community, also supplies important information through his compilation of the correspondence between Noyes and his family and his religious associates. Of the secondary sources, Whitney R. Cross, The Burned-over District: The Social and Intellectual History of Enthusiastic Religion in Western New York, 1800-1850 and Thomas's The Man Who Would Be Perfect are especially significant for understanding this period of crisis in Noyes's life.

Noyes's conversions gave him a freedom from depression, from a lifelong doubt and confusion, which resulted directly in his greatest social theories. Noyes believed that his conversion to Perfectionism changed him from a boy into a man. $\mathrm{He}$ experienced a feeling of liberation that resulted in his most creative period, signified by 
his development of the theory of Complex Marriage. This was a doctrine of group marriage which would exist in a society of holy-indeed, perfect-people. This was to become the founding doctrine of John Humphrey Noyes's greatest work, the Oneida Community. But Noyes, himself, admitted that were it not for his need to practice what he preached, he might not have had the courage to publicize, much less live, the idea of Complex Marriage. How he grew from a troubled theologian to the selfconfident author of Complex Marriage is the subject of Chapter V.

Among the most essential works to be considered in this chapter is Noyes's own Confession of Religious Experience, the two volumes by G. W. Noyes, and the Oneida Community publication Bible Communism, which explained its beliefs to the doubting and bemused outside world. In addition, Norman Walter Haight's unpublished dissertation, "Faith and Freedom in Christian Utopia: An Analysis of the Thought of John Humphrey Noyes and the Oneida Community," provides an important conceptual framework to this chapter through its presentation of Noyes as moving from systematic theology to a practical social religion, based on human need. Maren Carden's Oneida: Utopian Community to Modern Corporation is also helpful in clarifying Noyes's shift from theologian to "sociologist."

In conclusion, Noyes was a brilliant social thinker who used the Bible to free himself and his followers from an oppressive, conservative, all-pervasive religion. His daring theological leap-declaring that the Second Coming of Christ had already occurred-allowed him to quit trying to save souls and to turn to establishing social institutions for the already saved. Religion was no longer a set of proscriptive strictures; religion provided for Noyes his greatest liberation. With this freedom, Noyes created, not a new church, but his ideal society. 


\section{CHAPTER II}

\section{FAMILY}

They see in the vague distance, magnificent palaces, green fields, golden harvests, sparkling fountains, abundance of rest and romance; in one word, HOME-which is also HEAVEN. ${ }^{\text {H }}$

In his Confession of Religious Experience, John Humphrey Noyes dismissed his family in two brief paragraphs. He summarized his father as a successful merchant but no professor of religion, his mother as a conscientious, but independent church member. His own upbringing he passed over in one sentence in his mother's paragraph: "She had her children baptized, and took much pains to educate them in the fear of God." Noyes then skipped directly to his nineteenth year. ${ }^{2}$

Nevertheless, Noyes caught the essence of his parents' personalities in his almost off-hand remarks. The elder John Noyes was born at Atkinson, Massachusetts, in 1764 , the scion of a pioneer family which had settled in that colony in 1633 . He made the most of a scanty education by earning a living as an itinerant teacher in New England until the age of twenty-seven. Then, with a six hundred dollar inheritance from his father, he entered Dartmouth, graduating with honors in $1795 .^{3}$ Then followed two years of teaching at a private academy, and two years of tutoring at Dartmouth where one of his pupils was Daniel Webster. ${ }^{+}$During this time Noyes prepared himself for the ministry, but quit after only a brief trial of that profession.

John Noyes left no explanation for all this "flying from one thing to another." His son, however, who later did much the same thing, understood. In 1877. three decades after his father's death, John Humphrey Noyes composed a memorial of his 
father. There he noted that the school, academy, college, and pulpit were not his father's "natural sphere," that he was too ill at ease and too bashful to find these positions congenial. ${ }^{\sigma}$ This tendency to bashfulness (indeed, to an almost crippling shyness) was well marked in the Noyes family. The elder Noyes had four brothers, all of whom married their own cousins because they were too bashful to seek wives outside their family. Parker reports that this trait was called "the Atkinson difficulty," after the Noyes's hometown. ${ }^{7}$ John Humphrey, himself, spent his young manhood struggling to overcome the painful effects of "that infernal diffidence." ${ }^{8}$

John Noyes finally found his niche in society, when, at the age of thirty-six he moved to Brattleboro, Vermont, and began a career in business. In less than one year, he rose from clerk to head of a farm styled "Noyes and Mann," a company that began by trading manufactured goods for the wood ashes that were the product of the landclearing efforts of the burgeoning farming population. "Noyes and Mann" made these into pot and pearl ash which they sold for a large profit. Secure in his success. John Noyes blossomed. As his son put it:

In the highways and by-ways of business he was a born Solomon with a modern college education superadded. I have never seen his equal in conversational teaching. He charmed everybody with his practical wisdom and his genial stories.

One of those captivated by this geniality was Polly Hayes, the nineteen-yearold daughter of the tavernkeepers in Brattleboro with whom Noyes lodged. Her father, Rutherform Hayes, had started out as a blacksmith but soon turned to the more lucrative innkeeping business. ${ }^{10}$ That the Hayes Tavern (also called the "Big House") was a great success was due at least as much to Polly's remarkable mother, Chloe Smith Hayes, as to her father's Yankee business sense. Chloe Hayes was an intenscly 
religious woman, with a deep, Puritan need of introspection and sense of duty. She felt that she had to fight all her life against a love of artistry and beauty which she indulged in flower gardening and fancy needlework. She would never permit herself to do her beloved embroidery on the Sabbath, but would push her work basket as far under the bed as possible lest she be tempted. She feared this passion for beauty and tried to control it with incessant work. ${ }^{11}$ She raised eleven children, waited on the customers of the tavern, and became known as the best cook in Southern Vermont. ${ }^{12}$

In 1780 , this Yankee and this Puritan gave birth to their first child. a daughter named Polly. Polly showed from her earliest youth the same religious sensibility as her mother. However, she seemed to have felt a much greater assurance about her religion, and did not suffer from the fears and doubts of her mother. ${ }^{13}$

Polly Hayes met John Noyes when she was nineteen and he, thirty-six. She was, she recalled later, "delighted to hear him talk," as he discoursed on morality. philosophy, and science. ${ }^{14}$ Their son, John Humphrey Noyes, later noted that "it was in fact, the courtship of Othello and Desdemona over again." The courtship languished at first due to Noyes's extreme shyness "in matters of the heart" and Polly's being entangled in another engagement. ${ }^{15}$ Finally, they were married in 1804 , and set up housekeeping in Brattleboro.

Noyes had the good fortune to settle in an area of relatively steady and increasing material progress. Brattleboro was one of the principle towns in the Connecticut River Valley of Vermont. At the turn of the nineteenth century, this area was no longer untamed frontier, but it was still uncrowded and good land was available. Credit was easy to come by. Many more people were able to achieve their dreams of independent yeomanry or self-employment as shopkeepers or mechanics in this region 
of Vermont than in neighboring southern New England, Nova Scotia, or New York's Hudson-Mohawk Valley. In Vermont's Connecticut River Valley, at least three-fifths of the adult male inhabitants fitted this description. ${ }^{16}$ A smaller proportion of early settlers was able to acquire great wealth, usually through the avenues of transportation improvements (roll roads and canals), land speculation, financial services, and the law. ${ }^{17}$ Noyes, senior, moved easily between these two groups, becoming popular and respected enough to be elected first to the state, then to the national, legislature.

The Vermont where Noyes eventually married and raised a family was not only distinguished by economic expansion. In the post-Revolutionary years, Vermont was especially characterized by religious, social, and political ferment. The years following 1790 saw "the failure of the standing order," especially in the Connecticut River Valley. ${ }^{18}$ This part of Vermont had been settled by conservative Calvinists, strict New Lights who repudiated the Half Way Covenant of 1662 and tried to recapture Calvin's teachings regarding predestination, election, and the depravity of man. These New Lights, whether Congregationalist, Baptist, or Presbyterian, were strongly evangelical and labored to seek out sinners and return them to the church. By the Revolution, two-thirds of the valley's settlers held these Calvinist beliefs. ${ }^{19}$

Following the war, however, new waves of religious liberalism inundated Vermont. Deism, especially, flourished before 1800. This rational religion contradicted Calvinism at every point, holding that mankind could, through reason, perfect itself, and that nature was its most valuable religious guide. The intense Vermont delight in Deism was caused equally by a popular revulsion against Calvinism and by a fervent attachment to French rationalism. The French diplomatic alliance that made possible 
American independence, and the subsequent French Revolution with its unleashing of republican hopes, further cemented this bond. ${ }^{20}$

Arminianism or, broadly, the belief that man could save himself-a direct denial of the Calvinist doctrine of Election-was the second major religious notion to take hold in Vermont. Arminianism became a pervasive force throughout Vermont society, appearing in new religions such as Universalism and Freewill Baptists, and informing politics with a democratic bias. ${ }^{21}$

The Calvinists were not about to give in to these religions based on unsound doctrine and "free-thought." Politics compounded their struggle to return to the old ways. The Vermont old guard had to contend with the innovative democracy unleashed during the Revolutionary Era. Early in the Nationalist period, the conservative Vermonters had the benefit of constituting a powerful majority in the state. In the Connecticut River Valley, Tories had been common; after the war, adherence to the Federalist cause was the predominant political orientation. Even as late as 1814 , this area of Vermont sent delegates to the Hartford Convention, the last gasp of pure Federalism.22 ${ }^{22}$ These Federalists tended also to follow strict Calvinist religions. In both religion and politics, then, at the end of the Revolution, the majority of citizens of the Connecticut River Valley had deep idcological reasons for fearing popular upheaval in religion as well as politics. ${ }^{23}$

Toward the turn of the century, they had increasingly more to fear. ProJeffersonian "Democratic Societies" sprang up all over western Vermont and were much infected with the Jacobinism of the French Revolution. While no Democratic Societics existed in the Federalist Connecticut River Valley, at least before 1796, the democratic ideas from western Vermont poured in. ${ }^{24}$ By the state elections of 1800 , the 
republicans garnered 10 percent of the gubernatorial votes and 25 percent of the congressional votes cast in the Connecticut River Valley. In the period 1808 to 1816 , in the Noyes's home county of Windham, the median town-level republican vote was 42 percent. $^{25}$

These radical changes in religion and politics plunged the region into continual social disequilibrium. Both segments of Vermont society saw themselves threatened with dissolution as they moved steadily to opposing ends of the ideological spectrum. As Randolph Roth points out, these Vermonters were:

at once the world's most radical democrats and the latest conservators of New England's communitarian traditions . . . a people who were democratic by conviction and predicament, but whose aspirations and society were jeopardized by diversity, by partisanship, and by a simultaneous commitment to equality of condition and equality of opportunity. ${ }^{26}$

Interestingly enough, the people of Vermont and John Humphrey Noyes would both take the same path in their search for social stability: they both saw in religious revivalism and reform movements the means of ordering and balancing this fluctuating, dynamic society. Noyes could never have been immune from these social upheavals, with his father a conservative businessman, his mother a traditional Calvinist, and all living in the heart of what would later be called "the burned over district" (burned by the intense heat of passionate religious revivals. ${ }^{27}$

John Humphrey Noyes was born in Brattleboro, Vermont, on September 3, 1811..$^{28}$ His father was called from the meeting which had just elected him Representative to the state legislature to attend this long-desired event. John and Polly Noyes already had three daughters: Mary, Elizabeth, and Joanna. ${ }^{29}$ But it was not simply the birth of a male child that so pleased the parents. Polly Noyes, after the birth of Joanna. had suffered a severe depression that brought her "an active 
conscience and sleepless nights." She feared that she was going insane. In her memoir published in 1866 , she vividly recalled the day when she broke free of her depression. While watching her three daughters playing she was stricken with terror lest she die and leave her daughters to be raised by someone else. At this time her prayers for relief from these despairing feelings were answered. God assured her that she would not die, that she still had many tasks to accomplish. ${ }^{30}$

Her subsequent pregenancy was surrounded by a religious aura and she was continually in "a state of high religious joy." ${ }^{31}$ When she gave birth to her son, and saw that he was, in her words, "a proper child," she dedicated him to the Lord and prayed that he might grow to be a "minister of the everlasting gospel."32 Thus, as Thomas points out in his psycho-biography of Noyes, Polly Noyes had a tremendous emotional investment in her son. ${ }^{33}$ She was determined to keep his growth and education as her sole province, and she managed to do so with an uncommon strength and dedication. Because she was intensely religious, her son was bent in the same direction.

This maternal control over childrearing was still quite unusual in the New England family in the early years of the nineteenth century. While childbearing and childrearing had always defined the role of women in New England, their efforts had always been directed by the family patriarch. Men were considered to possess both stronger reason and morality. Thus, the responsibilities for the moral and religious education of the children, and even for the teaching of basic reading and writing. belonged to the father. His control of the children began as soon as they were weaned from the mother's breast. Sons, especially, were under the almost exclusive 
guidance of thier fathers; ideally mothers had little influence over the rearing and education of their sons. 34

It was only during the moral crusades of the mid-nineteenth century that women-because of the newly appreciated supremacy of their moral natures-began to be seen as the proper and often sole guide of their children's upbringing and education. ${ }^{35}$ The mother gradually became the primary parent, relegating the father to the roles of "part-time disciplinarian and audience, and full-time provider." ${ }^{36}$

Polly Noyes's expanded role was thus a precursor of what would become the popular ideal of woman's duty by mid-century. However, her influence over her son did not derive from the later conception of a moral hierarchy which placed women by nature at the top. Instead, two reasons unique to the Noyes family underlay her added authority over her children. First, her husband abrogated religious control over his children; religion was his wife's concern, not his. Polly Noyes had to fight for her position, but she was successful both in her choice of neighborhoods where the family lived and of the schools and colleges attended by her children. But even more influential in her control over her children were her husband's frequent absences for business and political reasons. By default, she had almost exclusive control over her children, at least until John Humphrey was ten.

As already seen, the elder Noyes's official political career began the day of his first son's birth. Following his years in the Vermont legislature, he was sent in 1815 to the House of Representatives where he spent one term. Noyes did not like Washington; he missed his family and was bored in the formal and unfamiliar Washington society. ${ }^{37}$ Nevertheless, local and national politics and business kept him frequently away from home until he retired when John Humphrey was ten. 
Thus John Humphrey Noyes was raised primarily by his mother. $\mathrm{He}$ and his mother were emotionally entangled in a way that was not common much before midcentury. $^{38}$ It is therefore possible to surmise that he absorbed from birth the atmosphere of moral fervor with which she surrounded him. However, it is difficult to learn much more about his childhood; too little factual information has survived. Only by using tools from fields outside of history can informed guesses be made about the childhood of Noyes and how his upbringing affected his adult personality. Certain psychological models posit the source of much of Noyes's adult behavior in this early stage of his life. It goes without saying that Noyes would have been ignorant of this whole field of thought had he written his social autobiography. Nevertheless, psychology can help the modern student to understand some of Noyes's subsequent behavior, some of which would be quite puzzling without its illumination: his psychsomatic illnesses, his lifelong reliance on his immediate family, his crippling shyness, his lack of confidence in his abilities, his mental breakdown in 1834 , his obstinence, his social and moral-as differentiated from theological-religious orientation.

A useful psychological paradigm is Erik Erikson's "Eight Ages of Man." ${ }^{30}$ This model sets forth eight stages of individual growth, progression to each new stage relying on the successful completion of the one before. Each stage presents some problem, some crisis of identity, which an individual must solve on three different levels, the biological, the psychic, and the social. At certain ages an individual becomes ready to begin a new life task would could either prepare him for the next step or impair his development in such a way that future tasks become more difficult and the crises aggravated. Erikson's model is explicitly historical and cultural in that it 
recognizes how personalities change over time and how individuals and society interact to bring about change and growth. ${ }^{40}$

The first stage occurs in earliest infancy and involves the conflict between basic trust and distrust. The first social achievement of an infant is his ability to let his mother out of sight without undue anxiety, because her return has become both an inner certainty and an outer predictability. For the infant John Humphrey, his first year was comfortable and peaceful. He had his mother's special attention during this stage since his brother George was not born until 1813.41 Polly Noyes's emotional commitment to her son would also have made the accomplishment of this stage, and the corresponding acquisition of a rudimentary ego identity, highly probable.

The second of Erikson's stages, the conflict of autonomy with shame and doubt, involved the crisis from which it is likely that Noyes's later personality problems developed. Erikson holds that in this stage, somewhere around the age of two, the child must be encouraged, literally, to stand on his own feet. The child must be allowed by the parents to develop a sense of autonomy, but must be guided firmly because of the still undeveloped nature of his sense of discrimination. The negative side of this autonomy is shame and doubt. If denied the gradual and guided experience of autonomy, the child will turn against himself his urge to discriminate and manipulate. He will have the feeling of being completely exposed, that is, literally selfconscious. The child will be ashamed. As Erikson wrote, "from a sense of loss of selfcontrol and foreign over-control comes a lasting propensity for doubt and shame."

The chances are good that Noyes was subjected to a great deal of shaming as a small child. Since his mother was a strict Calvinist, she probably adhered to childrearing practices which were intended to prevent the growth of autonomy in young 
children and to break their wills. Many Calvinist parents intended to instill a lifelong sense of shame in their children in the hopes of insuring their salvation. ${ }^{42}$ Therefore, it may reasonably be supposed that young John Noyes would have acquired a sense of shame instead of a feeling of autonomy under his mother's control. His father, more of a Yankee than a Calvinist, might have been a mitigating influence to his wife's religiousity, had it not been for his frequent absences from home.

There is one more clue to John Humphrey Noyes's failure to achieve a sense of autonomy during this stage. At the age of three he was severely burned when he fell into a tub of clothes just removed from the boiler. It was twelve days before he stood on his feet again, and four months before his wounds were healed. ${ }^{43}$ Certainly he would have had to be even more dependent on his mother during this time, instead of taking the psychologically necessary steps toward autonomy.

Erikson's third stage, the crisis of initiative versus guilt, would have been a difficult one for the child because of his failure to resolve the previous crisis. Erikson points out that, "initiative adds to autonomy the quality of undertaking. planning, and 'attacking' a task for the sake of being active." The opposite side of this coin, resignation, guilt, and anxiety, can occur because of rivalry with siblings over unquestioned primacy with the mother. There should also appear a sense of moral responsibility by which the parents can manipulate the child through his conscience. However, the child who has had problems acquiring an autonomous identity may develop an over-obedience even more strict than the parents required. Moreover, lasting resentments may be built up against parents who do not seem to live up to the child's newly formed scrupulous conscience. "One of the deepest conflicts in life," Erikson states, "is the hate for a parent who served as the model and the cxecutor of 
the superego, but who (in some form) was found trying to get away with the very transgressions which the child can no longer tolerate in himself." Finally a residual effect of this crisis can find the adult turning this resentment against himself by a "plunge" into psychosomatic disease.

Once again, Erikson's psychological scheme can be applied directly to Noyes's life. At age two, he lost his privileged place with his mother when his brother, George, was born. Much later, he also revealed a profound resentment of his mother, over her initial refusal to submit to what he claimed was a divine commission to religious leadership. Noyes's reiterated demands that she consider herself his child to be ruled by him produced in her an unbearable "despair that I had never before experience." ${ }^{\# 4}$ The psychomatic illnesses predicted by Erikson's paradigm also plagued Noyes throughout his life. He recorded how his physical system "sank" when he was in emotional conflict; he was "almost sick with a cold" at the time of his first conversion experience; during his famous "New York experience"-what a later age would call a nervous breakdown-he suffered from severely inflamed feet which cleared up "at the same time [my spirit] passed into a state of permanent peace." The examples could be greatly multiplied thorugh his life..$^{45}$

The fourth stage, industry versus inferiority, prepares the child to be able and eager to learn and to collaborate with hours. His "ego boundaries" include his tools and skills, and he learns to work with diligence to complete a task. Further, he now begins his schooling in order to learn the tools provided by his culture. The child who fails to complete this task will have a sense of inferiority and inadequacy. As will be seen, two potential work worlds were presented to Noyes as a young boy. Through his mother's wishes he was to be prepared for the world of religion, and not for the 
mercantile, political world of his father. He learned his cultural tools very well, but he had great difficulty using them until he could finally resolve the problem of a career for himself. Again, John Humphrey Noyes's crippling shyness at college could be more reasonably explained by a failure completely to negotiate this step in his development, rather than by the traditional justification of the "Atkinson difficulty." Further, Noyes as a young man continually doubted his abilities and achievements. ${ }^{46}$

Thus, if Erikson's paradigm is accepted, young Noyes first began his schooling with severe psychological handicaps. He had failed to develop an autonomous personality, he was dependent upon his mother, he was shy, and lacked self-confidence. Also unsettling was the family's move in 1817 from Brattleboro upon the retirement of Squire Noyes from politics. They settled in the nearby village of Dummerston, where John's formal schooling began. Despite his social problems (he was often violent and hostile when provoked), ${ }^{47}$ the changes caused by the birth of his brother Horatio in 1815 and sister Harriet in 1817, and his new environment, he was a good student.

He further pleased his mother when, at age eight, he was first converted at a religious revival at the neighboring town of Putney. ${ }^{48}$ Although conversion at this age was considered precocious, youthful, revival-inspired conversions were becoming more common at this time. Whereas the Puritans of the seventeenth and eighteenth centuries had expected most authentic conversion experiences to occur in young adulthood, the nineteenth-century revivalists especially targeted youth. ${ }^{49}$ Even so, age eight was seen as too young for a real conversion, and it was no cause for alarm when John Humphrey soon lost his early enthusiasm when he was sent away to school in Amherst, Massachusetts. 
Noyes never mentioned the experience at Amherst in his spiritual autobiography, perhaps because it was such an unhappy one. As the following extract indicates, the child tried to follow his family's religious regimen, but he could not overcome the homesickness of a nine-year-old away from his family for the first time.

\author{
Amherst, May 26, 1821 \\ Saturday, P.M.
}

Dear Mother: As school does not keep this afternoon I have begun a letter to you. It is rather too soon, methinks, after our separation. However, as you told me that I must write long letters to you, and as I am not very quick of intellect, I thought it best to begin soon enough.

I have been pretty contented since you left me, except last evening I was rather inclined to be homesick. I sat in my chamber alone, the wind whistled around the house. I began to think of home, and I became sad. I took my book, and looked over my lesson, then went to the book-store, and got me ink and paper, and begun [sic] me a journal, which I intend to write in every day. I like my boarding-place, and have but one or two objections, namely, there is no looking-glass in my room, nor drawers to put my clothes in ...

Sunday evening.-. . . I went [to meeting] in the afternoon. A Mr. Dickenson preached. A Testament, which was in the list of my books, was forgotten in packing up my things to bring down here. I missed it very much today. Mamma, I must say that when I am not reading. or writing, or studying, I am homesick. Yes, I am homesick. . . . How heavily the hours pass! What leisure moments I have I am obliged to spend in solitude. No companion, no bed-fellow, nothing new. This ain't happiness. But away with all this! I fear I have distressed you already.

Monday night.-Again alone and disconsolate. . . . When I am writing to you, or studying, or reading. I feel tolerably cheerful; but just at dusk, to sit in my room alone and think of home, I soon begin to feel my heart rising into my mouth; then a flood of tears is my only relief.

Tell Papa that I am studying Cicero, and that I have got to the fourth book of Virgil....

\title{
Yours affectionately, JOHN NOYES
}

\section{N.B.-Handwriting superexcellent. ${ }^{50}$}

Noyes's biographers do not mention whether he ever settled comfortably into school in Amherst. At any rate, he did not spend long there, for a major 
transformation occurred in his family. Squire Noyes decided to retire from business and devote his life to the education of his children. The sources mention that he had acquired a comfortable fortune-Parker adds that he had profited quite handsomely from the War of 1812 and that it was widely held that he certainly knew how to make money work for him. ${ }^{51}$ Both Noyes and his wife felt that Dummerston did not offer the proper educational advantages for their children, so another removal was planned. The Noyeses considered Amherst but Squire Noyes was partial to New Haven. Mrs. Noyes, however, believing that the religious future of her children was at stake, would not accede to her husband's wishes. Instead, she prayed for three months before she chose Putney, Vermont, as the site of their new home. Putney had several advantages: it was close to Brattleboro, in the same county (Windham); the family already had acquaintances there; the social and physical environment was similar to what they had known. However, to Polly Noyes the fact that Putney had been the scene of several recent enthusiastic revivals put a divine stamp of approval on the place. ${ }^{52}$ Accordingly. the Noyeses moved to Putney in 1821.

The tall, thin, ten-year-old boy who was the chief reason for his mother's choice to move, was, by and large, a normal boy of his time. ${ }^{53}$ The early home-leaving to go to Amherst was typical of boys his age. ${ }^{54}$ Interest in religion was normal and encouraged. There are even occasional glimpses of the young boy at play. He played soldiers with his playmates marching armed with mullien stalks, John Humphrcy usually in command. His sister, Joanna, once alluded to his "hunting, fishing, and riding all the time. ${ }^{155}$

In many respects, however, the childhood of John Humphrey Noyes was extraordinary. This was due to the prototypical nature of his family. The Noyes family 
exhibited qualities not characteristic of the American family until at least mid-century: maternal authority and control over both religion and education of the children, engagement in business instead of agricultural pursuits, and a consequent emphasis placed on education instead of work for the children. Of course, the family wealth-accrued solely from the father's business ventures-played no little part in the relative ease and varied options the family enjoyed.

Moving into a century which would be distinguished by the disintegration of the traditional social institutions-the old-style family, the self-sufficient agricultural economy, even gender roles-John Humphrey Noyes was forearmed. From his birth he had an intimacy with the type of family which would later become the norm. He never knew a subservient mother, nor did he ever engage in agricultural employment, nor was he expected to learn a craft or trade because of financial need. Noyes may have had some psychological problems, but he was fully prepared by his family life to be a social prophet in the nineteenth century. 


\section{CHAPTER III}

\section{EDUCATION}

We have daily schools for children in which common learning is taught, in connection with the fear of God and the law of love. But it is understood among us that the whole Association is a school: and all members, old and young, are supplied with books, and addict themselves to various branches of learning as they have opportunity. ${ }^{1}$

John Humphrey Noyes's education was compounded by two roughly equal experiences. The first was the continual agonizing search for an identity, separate from his family. At school he learned to follow increasingly rigid patterns of study, both to implement his search for self and to cover up the pain and depression that were consequent on the failure of his quest. The second experience derived from his high intelligence and love of learning. While he shrank from admitting these qualities to himself, disgusted by the sinful pride they revealed, his educational achievements were pronounced and publicly rewarded. A love of scholarship was planted early and deeply in him, by his academic father and at school and college. Noyes repressed this quality during his young manhood, but later, at the Oneida Community, it burst forth to such a degree that he could equate the Community with a school.

When the Noyeses moved to Putney in December, 1822, they transferred young John to a school closer to home, the Brattleboro Academy. According to Parker, Squire Noyes had donated the land for this school. ${ }^{2}$ John boarded there from 1823 to $1826,{ }^{3}$ but nothing more is known of his grammar school education. Yet it is easy to infer his intellectual ability from these scanty details, especially from his rapid and successful preparation for college while in Brattleboro Academy. 
John Humphrey Noyes's early academic accomplishments were special because speed and success were not usually the hallmarks of academies at this period. The academy was an innovation of the late eighteenth century to provide education for the "middling classes," that is, for the children of successful farmers, artisans, and professional classes. Its most noticeable characteristic was its seasonal nature since it was intended to provide education which complemented the patterns of the agricultural year. Most students pursued their studies only sporadically, in intervals before they were old enough to work on the farm or whenever their labor was not required. Going to school in fits and starts contributed to a wide age span among the students and to a very loose, unsystematic curriculum. Rarely could a coordinated effort be mounted to educate such a fluid, unpredictable student body. ${ }^{4}$ Noyes, however, was able to forge an education for himself out of these unpromising conditions, chiefly due to his own native intelligence. In addition, although he was a boarder, he was able to take advantage of his retired father's pedagogical expertise-although many years passed before he could appreciate his father's "confining me so rigidly to my studies.".5

Except for one traumatic incident, John Humphrey's years from age eleven to fifteen passed smoothly, if the lack of information in G. W. Noyes's compilation can be assumed to be of the "no news is good news" variety. The one difficult episode occurred just after John entered Brattleboro Academy. In April, 1823, the brother closest to him in age, ten-year-old George Washington, was taken severely ill, and John was sent for. Their sister, Mary, saw John approaching the house in tears. George recovered temporarily, and when John returned to the Academy he wrote home, "I have written but little in my diary, and I want to have you write to me about George, 
so what I can write in it." ${ }^{\text {6 }}$ In June, George did die, and the youngest boy, six-monthold William, had his name changed to George W. ${ }^{7}$

Well armed with the cultural tools learned at school, John Humphrey Noyes began his college career at Dartmouth in September, 1826. Typically, the choice of college had been the subject of protracted debate between his parents. His father had destined him for Yale. In preparation, John Humphrey bought himself a standing collar which was in particular vogue at that college. However, his mother felt that Dartmouth would be better for his morals, so there he was sent. He subsequently reported that all through his freshman year, his Yale standing collar was a "standing joke." 8

In his Confession of Religious Experience, Noyes ignored his four years at Dartmouth, probably because his ultimate conversion did not occur there. Nevertheless, Dartmouth provided him with another crucial element of his social experience. Here, again, he was intimately involved in another institution that-like the family-was undergoing rapid and convulsive changes. According to David F. Allmendinger in Paupers and Scholars, the early years of the nineteenth century saw dynamic structural transformations in the colleges of the northern states, not unlike those in other institutions. One of the chief sources of these changes was the tremendous growth of college student bodies. In New England, the period between 1750 and 1800 had been one of stable enrollment; after the turn of the century, the student population grew even faster than the whole area's 250 percent growth. For instance, for the decade ending in 1790, New England colleges had produced one graduate for every 6,495 persons in that area. By contrast, the decade ending in 1840 , 
saw one graduate for every 2,560 persons, and this ratio continued to decline throughout the century. ${ }^{9}$

Even more crucial than population growth was the social origin of the new students. They were drawn chiefly from New England's rural communities. A demographic crisis and a decline in available land pushed these young men off the farms and into the schools, in order to train for such professional positions as teaching, the ministry, medicine or the law. Too poor to afford Yale or Harvard, they began to be served by a proliferation of new colleges that sprang up on their own turf. ${ }^{10}$ The provincial colleges, which included Dartmouth, not only adapted their schedules to the seasonal labor patterns of their students, but they adopted inexpensive living arrangements and made tuition so cheap that they were often considered charities. Moreover, these colleges competed for students, further cutting costs. A poor student could attend a provincial college for half or two-thirds of the minimum required for Yale. ${ }^{11}$

Not only poorer, the new student bodies were considerably older than those in the previous century. Requiring more time in which to earn their tuition and board, these students pushed the average age up, especially in the period 1800 to 1860 . Of New England college graduates in the decade ending in $1760,71.1$ percent were twenty-one and under; only 8.6 percent were over twenty-five. At the New England colleges in 1810 , these percentages had changed to 51.7 aged twenty-one or less, and to $\mathbf{1 8 . 4}$ for those graduates older than twenty-five. Dartmouth in this period had percentages of 32.0 and 33.8 , respectively, in these two age groups. ${ }^{12}$ These older students created a new kind of student society. Accustomed to making their own way in the world, they were less dependent on their families and colleges. They brought to 
college society a new mixing of classes and ages, a feeling of independence that disdained collegiate authority, and a breakdown of the previous scholastic isolation in favor of commercial and social relations with the outside adult community. ${ }^{13}$

John Humphrey Noyes was not quite unique when he entered Dartmouth at age fifteen, but he was in the minority and he knew it. Awareness of his youth exacerbated his normal shyness and lack of confidence. In addition, at no time during his college and post-graduate career did he ever reconcile himself to the social disorder he saw in every institution he attended. Noyes's consuming passion was the search for peace, stability, and order. He was never to find it in the New England colleges of the early nineteenth century.

He was never happy leaving home, and, true to form, he became ill upon arriving in Hanover. His father stayed with him until he recovered from some "febrile symptoms," fearing that "leaving him in a strange place might depress his spirits." ${ }^{14}$ Little is known of his first two years at Dartmouth. One letter he sent home describes his daily schedule:

Up at five. Go to prayers at a quarter after. Then immediately go to recitation. Then have breakfast. Then study till eleven, when we recite in Graeca Majora, which takes up to an hour. Then until one we employ ourselves as we please. At one we take dinner, then we study till four, when we recite in the grammar, which takes an hour also. At a quarter before six we go to prayers, which with supper takes up the time till dark, leaving us only three-fourths of an hour in the evening to get our lesson in Livy for the next morning. ${ }^{15}$

This routine left no time for idleness. Moreover, physical hardships were constant. The school was in administrative and financial disarray in the aftermath of the Dartmouth College Case. It owed back salaries, could not afford upkeep on its buildings, tuition from the new type of student could not pay the bills. ${ }^{16}$ Fires during 
the freezing winter months were the exception, not the rule. The grueling schedule and Spartan way of life seemed to guarantee student unrest, especially among the older, more independent students (and this was indeed the case). Disorder, both individual and collective, was rampant on the New England college scene in the century between 1760 and 1860. While Dartmouth recorded at least one major incident of organized rebellion and several small annual occurrences of group violence, the greatest discipline breakdowns came in the areas of absences, tardiness, incomplete tasks, and disruption of routine. Most of the disorder arose from the need of the poor students to find work, a need which the unbending institution tolerated unofficially, but officially punished and recorded as inexcusable violations. ${ }^{17}$

John Humphrey Noyes fitted the official requirements perfectly. At the end of his freshman year, in an unusual letter from the school to the family, Roswell Shurtleff, Dean of the College Church, praised John Humphrey's steadiness and studiousness. Dean Shurtleff found favor with the soundness of Noyes's mind, and with his excellent study habits and added, "there is little danger but he will graduate a respectable scholar, and with the blessing of God become a pillar in society. ${ }^{18}$

John's deportment earned this praise. He disdained student disruptions and violence. While he wanted desperately to mingle in student society, for the most part he confined himself to his studies. In his junior year he began a journal, which he entitled "Fugitive Pieces, By the Author of etc., etc." Probably the most lasting impression gained from the few Dartmouth-era selections preserved by G. W. Noyes is that of an outsider wanting to be an insider. In spite of his self-exhortation that "whatever may be your lot, strive to be content," contentment was something Noyes never found at Dartmouth. He criticized his classmates, one for "engag[ing] heart and 
hand in a jolly scrape," another for being a pedant. While he "love[d] to see a person occasionally cast off the mast of dignity and ceremony, and give himself up to the entertainment of his fellows," he was unable to do so. He blamed:

that infernal diffidence, natural or acquired, which makes me when in company appear to myself and to everybody else a stupid dunce. Oh! for a brazen front and nerves of steel! I swear by Jove, I will be impudent. ${ }^{19}$

At Dartmouth, the disorder and conflict that pervaded New England colleges was reflected in John Humphrey Noyes's own life. He did not have a name for it, but his description of his internal conflicts coincided with modern ideas of adolescence..$^{20}$ Shortly after graduating, he looked back on his college career, and marvelled that,

My own experience convinces me that the changes which are wrought upon the mind of every individual as he passes through the stages of childhood, youth, manhood, maturity and age are incomparably worthier of attention [than changes in the external world]. The number of these changes deserves notice. It may be that I have less stability of character than most men; but I must confess that my views of men and things change so often and so essentially even in the course of a single year, that I almost lost all acquaintance with myself.

Noyes went on to track the changes he had experienced: first, credulity, an aversion to all society (with its resulting unpopularity), then a desire for popularity, a hunger for learning, a "fit" of stoicism which gave way to dissipation, and all culminating in a stage where "virtue, honor, and the dictates of conscience" were the guarantee of happiness. ${ }^{21}$

The Dartmouth years for Noyes were years of internal conflict. He wanted to assert himself, to be arrogant-"impudent." He studied human nature to learn how to get along with his fellow men. He played checkers (and lost to everybody) and recorded many a "proof that I am noted for my cheerfulness." Hoping that clothes would elevate his spirit, he bought himself "bell-bottomed pantaloons, square-toed 
boots, patent leather stock, and a pyramid-formed hat." Nevertheless, his journal recounts his frequent bouts of shyness, his horror and mortification when he committed small social gaffes. Once he forgot a lady's name and afterwards would "burn with shame" recalling the incident; he wished himself "a hermit or a savage." Ostensibly describing a friend of his, Noyes noticed that "the transition from boyhood to manhood, which usually determines the bent of future life, was a miserable though imperceptible change." 22

Nevertheless, part of this transition from dependence to independence was successfully accomplished. Noyes graduated Phi Beta Kappa in 1830, and made good an earlier promise to his father that he would give an oration at the commencement. ${ }^{23}$ Noyes probably thought that he was now prepared to enter the world of men: instead of choosing the ministry as his mother had always intended, he opted for the law. He went to study with his sister Mary's husband, Larkin G. Mead, in the village of Chester, New Hampshire. This incident, too, is passed over in his religious autobiography, but it was a serious crisis for him. As Thomas puts it in his psychobiography, during Noyes's brief, miserable law career, all his psychological "deep rents and fissures [began] to expand and press toward the surface."2t

In Erikson's model, the developmental stage Noyes was now experiencing involves the conflict between identity and role confusion. Childhood ends, and young people are "primarily concerned with what they appear to be in the eyes of others as compared with what they feel they are, and with the question of how to connect the roles and skills cultivated earlier with the occupational prototypes of the day." The danger at this stage is role confusion. Sometimes it takes the form of doubt about sexual identity; most often, this confusion is the result of an inability to sctlle on an 
occupational identity. Moreover, for a person like Noyes, who already had had trouble formulating a sense of autonomy, "delinquent and outright psychotic episodes" are common. ${ }^{25}$ As a student, Noyes was able to hold these episodes at bay. Only to his journal did he confide his desire for delinquency, or at least a carefree social mingling with the very students he had criticized as delinquent. His strength of mind and will, and the outlet provided by his journal, forestalled a psychic breakdown until 1834 .

Noyes also failed to achieve an identity as a lawyer. His career choice brought him "mingled mirth and misery." He did pass some pleasant social moments with a friend and his female cousins, but in his journal he revealed that his happiness was simply a facade: he was in reality miserable with jealously and longing for love. ${ }^{26}$ Erikson's paradigm demonstrates that this stage is marked by an initial "falling in love." At this level of adolescence love is an attempt to clarify one's identity, by projecting the self and seeing it mirrored by another. And, indeed, Noyes did fall in love, with Caroline M., a young woman studying at a neighboring academy. He wrote a poem to her in his dairy ("Mark, Caroline yon western sky"), and was tempted to ask her to marry him. However, he could not bring himself to undergo an emotional interview with her, so he took his cane and ran home to Putney. ${ }^{27}$

His first experience as a lawyer crushed him still further. Although he had assiduously studied Blackstone, his courtroom debut was a debacle:

a most shabby performance it was. I was frightened beyond all reasonable bounds. I stammered and trembled, and for a few minutes was utterly unable to fabricate a decent concatenation of words . . . the conclusion of the whole matter is, that (in the taunting words of 'Squire Spaulding) I 'did not plead worth a damn!"28

Faced with loss, confusion, and "the curse of other people's contempt," his only means of control was to go home. There he could recover his weak self-esteem and try to 
reestablish the only identity he had known, that of a son and brother. This was the beginning of a life-long pattern.

From this crisis, John Humphrey Noyes ran immediately into another. In August 1831, he attended a revival in Putney which would end by changing his life. Noyes's religious conversion will be discussed in Chapter IV. Suffice it now to say that his Confession of Religious Experience begins with this episode, and that he immediately determined "to be a 'young convert' in zeal and simplicity forever." ${ }^{29}$ He made an about-face and embraced the career for which his mother had always destined him, the ministry. To this end, he commenced the Hebrew studies required for admission to the Andover Theological Seminary.

Noyes never explained his exact reasons for choosing this path. As G. W. Noyes noted, John "could do nothing by halves," and when he made his religious conversion he had no choice but to go all the way with it and become a minister. ${ }^{30}$ But it is also possible to trace Noyes's emerging religious zeal back to Erik Erikson's model. Noyes was seeking his "ego identity" through his career. Obviously, his legal career had been a dismal failure, which only increased his anxieties. Perhaps he would be able to calm his tensions by following the path previously marked out for him by his mother. When she inquired of him why he was attending a religious revival, he replied, "to please her." But even after conforming to her wishes, Noyes could find no peace or security in his decision. Before submitting to God, he felt that:

The first duty which presented itself was that of overcoming my fear of man, and though it was like cutting off a right hand God enabled me to resolve and to execute the resolution of communicating to Mother my determination [to become a minister]. 
His anxiety mounted when his mother "seemed disposed to leave me entirely to myself." 31

Although Noyes at first assumed that he had solved the problem of his role in life by abandoning law for the ministry, and by attending a reputable school, he was destined to be disillusioned in both respects. Andover certainly qualified as the most distinguished school for the training of ministers, especially in its first-year program. ${ }^{32}$ Noyes was unable to take full advantage of the renowned course of study, however, and his year an Andover (1831 to 1832) only increased his psychic difficulties. He related in his diary that when absorbed in religion his "mind seemed to lose its faculty of self control . . my physical system sank under the intensity." His stay an Andover was spent in poor health and "spiritual desolation." Periods of spiritual enlightenment alternated with long bouts of depression. In addition to his personal crisis, the disordered atmosphere at Andover was a sore trial to Noyes. It surprised him that a theological seminary could exhibit the disorder and violence of the secular New England colleges. "Disputes, excitements, levity, and trifling with Scripture and sacred things became exceedingly prevalent amongst us, and the Holy Spirit was grieved away." Unable to stand the tension after six months, he, as usual, went home, seeking "leisure and solitude." ${ }^{.33}$

After a month, on May 29, 1831, he returned to Andover, but his depression had not lifted. The state of his health varied: on July 1st he found himself "unexpectedly improved," so that he was able to attend church services, but on July 4th, Noyes wrote in his diary that, "my health is so poor that I cannot conscientiously impose upon myself the effort which is necessary to faithful self-examination, though I would most gladly make it, if my body would bear it." On July 12th, he "had a 
miserable night." He dreamed of the cholera and awoke feeling as bad as if he had the disease. "An excessive dinner dreadfully increased my evils of body and mind." A week later, still "I am unprofitable and barren from day to day, and I would fain impute it to my ill health. ... I must try once more to combine spirituality with that cheerfulness which is necessary to health." 34

Illness of a psychosomatic nature had been a common feature of Noyes's life. Following Erikson's model this arose from a failure to negotiate the third developmental stage of initiative versus guilt. As a young adult, Noyes sensed that any show of initiative only brought him disaster-witness his depressing legal career and even his choice of the ministry. His efforts to "stick his neck out" brought him such failure that he reverted to a world of disease as an escape. ${ }^{35}$ Once he came to grips with himself in the $1840 \mathrm{~s}$, he was also able to grapple with disease. But the concept of disease was never far from his mind, and would always play a crucial role in his theology.

Now, however, Noyes was terrified by an added threat: instead of a malaise, depression, or such normal, minor somatic illnesses as he used to suffer, a real epidemic loomed. Although the initial cases of the first cholera epidemic to hit the United States did not occur until the summer of 1832 , cholera had long been raging in Europe. By fall and winter of 1831 , the westward spread of the disease was being reported all over America. ${ }^{36}$ Noyes could not have failed to learn of it, perhaps in a sermon or newspaper account. These media constantly held up to Americans the example of the immoral poor in the filthy cities of Europe who were stricken with cholera as punishment for their sins. ${ }^{37}$ Noyes, who at this time considered himself a miserable sinner either because he was not saved or because he was too proud of 
being saved, saw himself as just the kind of moral and spiritual degenerate who was being swept away by the cholera. His terror of the imminent and uncontrollable cholera erupted in his dreams.

Andover offered little to raise either Noyes's depressed spirits or his health. Even a pledge to devote himself to missionary work failed to ease his mind. As a result of this pledge, he had joined a group of Andover students called The Brethren, who had all made the same vow. Although Noyes did not follow through with his missionary promise, membership in this group provided him with one of his most important tools for social control for his future communities, first at Putney, Vermont, and then at Oneida, New York. This method involved the criticism of one member by all the others. While he always considered it an ordeal to be told his faults "in the plainest way possible," Noyes found that this criticism was useful for forestalling sin and forming character. Even disease could be overcome by criticism: Noyes later called it a hygienic agency, "a new curative." 38

While Noyes had had nothing to say about his four years at Dartmouth, even his short stay at Andover elicited many comments in his religious autobiography. In addition to the method of criticism he learned, he also found some of the lectures to be of great importance. His year's study was confined to Hebrew, Greek, and a "collateral modicum" of German hermeneutics. The latter course was taught by Dr. Moses Stuart, professor of Scared Literature at Andover from 1810 to 1848 . For him, biblical criticism was simply a tool for promoting conservative Calvinist theology. ${ }^{39}$ Stuart was an important intellectual link with Noyes's own religious heritage. In his Confession of Religious Experience, Noyes recalled that he had been a disciple of Dr. Stuart, and singled out that professor's biblical interpretations that had been most 
meaningful to him. Nevertheless, Noyes always preferred reading biblical texts on his own, never having conceived an interest in commentaries. ${ }^{40}$

In fact, Noyes considered his private reading of the scriptures to be the best part of his education at Andover. He developed his own method which enabled him to control his anxieties over his career and his unshakable depression by means of compulsive work habits. His method was to select some spiritual quality and read the gospels in succession at one sitting in order to note down every passage relevant to his subject. After going through the gospels daily for months, he applied the same method to the epistles. Besides the spiritual gains, he also found pleasure in the intellectual exercise and in his acquisition of the facility of rapid reading. ${ }^{41}$

At the end of his first year, Noyes began to be restive at Andover. Several of his classmates were transferring to Yale, to attend the more profound and interesting lectures of Dr. Nathaniel Taylor. Taylor's reputation was a great inducement for Noyes, too, to consider Yale. However, the primary attraction of Yale was that it promised to provide him plenty of leisure in order to devote the bulk of his time to his "favorite study of the Bible." Should he remain at Andover, he would be required to study what he called "technical theology and the writings of the 'standard divines." But he was unable to reach a decision on which school to attend. Casually, he resorted to a random opening of the Bible.

Whether it was by chance ... I will not say, but the passage that my eyes first fell upon was Matt. 28:5,6. "Fear not ye: for I know that ye seek Jesus which was crucified. He is not here." I could not but be amused at the coincidence of the passage with the facts of the case.... I see no reason why I should be ashamed to confess that this little circumstance broke the equilibrium of my doubts, and settled my determination to go." ${ }^{n+2}$ 
Noyes's decision involved more than simply a change of school. He was, in a sense, making another career change. Yale offered opportunities for would-be missionaries, of course, but Andover was particularly influential in this regard. Andover students had taken a central role in the founding of the American Board of Commissioners for Foreign Missions in 1810. In fact, the founders of the American Board were the same Andover students who had started the society of the Brethren, with the goal of persuading the Congregational Church to support them as missionaries. Because of this close traditional association with missionary activities, subsequent Andover students were in a particularly favored position and were much in demand. ${ }^{43}$ Noyes realized that in leaving Andover he was "sacrific[ing] valuable connections." ${ }^{144}$ In addition to creating another career crisis, leaving Andover had connotations of abandoning his past. Andover symbolized the traditional, conservative Calvinism which his mother had taught him. Perhaps he sensed that his mother represented Old Testament theology, and that her teachings had to move aside for the New. As he wrote later in 1845 , "I will allow that [my mother's] educational system has been to that in which we stand as Judaism to Christianity. . . J Judaism was not valuable in itself, but only as an antecedent of Christianity..+5 Andover Theological Seminary, founded in 1809 as a bulwark against liberalism, especially against Unitarianism, was intended to be a beacon to conservative Congregationalists. ${ }^{46}$ Noyes hoped to find a newer religious orientation at Yale.

While Yale Divinity School was in no sense a Unitarian institution, it did follow a more liberal bent. Its chief theologian, Nathaniel William Taylor, was so influential that Yale's theology became known as "taylorism." From 1822 to 1857, he was professor of Didactic Theology. The thrust of his teaching was to retain as much 
conservative Calvinism as possible, while rationalizing and incorporating the liberal ideas being spread by the revivals of the Second Great Awakening. His theological enemies accused him of Arminianism because he taught that man could freely choose good or evil, and he insisted that $\sin$ was a freely chosen moral failure. Man was morally responsible; God had not made man so depraved that he was unable to choose virtue. ${ }^{47}$ As the child of his mother and while a student at Andover, Noyes had feared "the heretical reputation of Dr. Taylor. ${ }^{48}$ But, after absolving himself of the responsibility for the choice through his serendipitous reading of Matthew 28, he broke with the past, and in the fall of 1832 , entered Yale Divinity School. ${ }^{49}$

Although his time at Yale (from 1832 until February 1834) often exhibited the same interior confusion, doubt, and unsure self-identity of his previous college experiences, there were many important differences. First, he learned how to dispute points with others and to make himself heard. At Yale he acquired enough selfconfidence freely to express his opinion, even in the face of stout opposition. Once, while being examined for his license to preach, he was drawn into a "long and warm" discussion with Dr. Taylor himself. While he disagreed with Taylor, he still received his license.

This self-confidence in controversy, Noyes admitted, was probably due to Dr. Taylor's own teaching methods. When the entire seminary was agitated by several ongoing controversies (such as whether all Christians will necessarily suffer persecution-Noyes holding the affirmative on this point), "Dr. Taylor was generally called in as arbitrator, and generally took sides with the conservatives, against the doctrine of the more zealous part of the school." But, Noyes continued, "he laid no 
obstacles in the way of free discussion, and ... he exhorted us to 'follow the truth, though it should cut our heads off."'50

A consequence of this new confidence, which Noyes identified as his spirit rapidly increasing in strength, ${ }^{51}$ was a new ability to relate to the outside world. $\mathrm{He}$ did not abandon his idiosyncratic, solitary Bible study at Yale, but he did make overtures to society. Soon after entering Yale, Noyes helped form an Antislavery Society in New Haven, one of the first such groups in the country. He also devoted many leisure hours to "religious labor among the colored people of that city." ${ }^{52}$ Here, he may have been testing his new-found strength against his fear of the dreaded cholera. No city, no matter how small, escaped the epidemic and blacks were usually the worst sufferers. Because of the poverty in which they lived, the incidence of cholera among blacks was twice that of whites in some northern cities. ${ }^{53}$ The disease, which had diminished in late 1832 , returned with a vengeance in 1833 and $1834 .^{54}$ Connecticut's proximity to New York, the hardest hit state, would virtually guarantee its contagion. ${ }^{55}$ In light of these facts, Noyes's foray among the black inhabitants of New Haven assumes a meaning beyond religious solicitude. It was a test of his manhood; his freedom from the disease may have combined with other incidents to prove to him that he could be an independent adult.

But, clearly, the highlight of his stay at New Haven was his learning to preach. In August 1833, Noyes's class received its license to preach. As part of the course of study, the students were required to gain practical experience in the ministry by performing pastoral duties in a church lacking a regular minister. It was thus on a small village congregation in North Salem, New York, that Noyes first practiced his preaching. He recorded his experiences in his college diary. At first, his preaching 
career seemed to be destined for the same failure he had encountered in the courtroom. He read his first sermon to the congregation, with such disastrous results that he resolved never to do so again. Sunday, August 25, 1833, was a fateful day for Noyes. He went to the meeting house at the time appointed for the meeting and found an empty building. After half an hour, a few people straggled in to hear him preach. Again, he was "wickedly discouraged. . . . It was hard work. The service dragged, and I was ready to give up in despair." But he tried again at the afternoon service, and although he "blundered some," he was encouraged that he was making progress. Finally he achieved a great success at the evening service. He felt that he gave the "respectable" audience a "faithful exhortation" contrasting the righteous and the wicked. After this "solemn and delightful meeting," he wrote in his diary:

For the first time today I have performed the Sabbath duties of a minister. It is wonderful to think how God has strengthened me. A year ago my nerves were so sensitive, and my voice so weak, that an evening meeting would spoil me for the succeeding day. . . . Now it actually does me good to preach. My nerves are quiet, my voice grows strong by exercise, and I felt better today when I had finished than when I began. Bless the Lord, $\mathrm{O}$ my soul! $!^{56}$

In his religious autobiography, Noyes later recalled that he used his own Biblestudy method to prepare his sermons. He would read through the New Testament to study the subject on which he planned to preach. He then talked extemporaneously, or from an outline. He preached about six times a week and visited his congregation daily. At the end of his stay at North Salem, he received twenty-five dollars, the most money he ever received for his ministerial duties. Although he was satisfied with his labors, he never did achieve his heart's desire, a "glowing revival." ${ }^{157}$ Nevertheless, he felt for the first time that he had finally put aside the "bashful boy, without any clear, strong purpose of life" and had begun to "exercise the strength of manhood." 58 
Some degree of self-identity had come to Noyes while in college. While he usually felt fully secure only with his family, he did manage to carve out a small niche of autonomy for himself at Dartmouth, Andover, and Yale. However, until he began public preaching, this identity was for the most part negative: Noyes could only see himself in opposition to the teachings, institutions, and fellow students he encountered. Noyes constantly battled with his obsession to overcome his sins and the "guilty passages" of his life, to achieve some obscure but ardently desired "ideal standard" of holiness. To Noyes this holy state corresponded to the cessation of his constant depression, to the end of his "season of sorrow," to freedom from his feelings and impotence and disgust over his status with God. His "wish was to feel a calm, holy, unreserved confidence in God." ${ }^{159}$

Above all, he desired inner peach. But this craving always conflicted with his need to feel secure in his social environment. He was never able to achieve a balance between the two desires, and, as a result, both eluded him. At each of the schools where he studied, Noyes found himself increasingly estranged from the institution and his fellow students. At both Dartmouth and Andover, his distrust of the scholarly dictates of his professors coincided with his disgust for the "worldliness and pride and unholy ambition" of his fellow students. ${ }^{\circ 0}$ At Yale, he found himself-at the moment of his great personal breakthrough as a preacher-cast out from its haven because of his nonconforming religious beliefs.

Noyes always remembered with some fondness the benefit he derived from Yale, especially Dr. Taylor's metaphysics and the "free atmosphere of a 'heretical' seminary." ${ }^{61}$ Nathaniel Taylor's teachings on free will were quite important to Noyes, for all the while he was absorbing these ideas, he was stcering a course far beyond 
their limited scope. While at New Haven, Noyes discovered Perfectionism, the epitome of free will, where one could choose to be perfect and assuredly saved. In opting to "graduate" as a Perfectionist, Noyes, in a move recommended by Dr. Taylor, would lose his license to preach in April, 1834. ${ }^{62}$ 


\section{CHAPTER IV}

\section{RELIGION}

There can be no doubt that as a matter of fact a religious life, exclusively pursued, does tend to make the person exceptional and eccentric. I speak not now of your ordinary religious believer, who follows the conventional observances ... but such individuals [who] are "geniuses" in the religious line; ... such religious geniuses have often shown symptoms of nervous instability. Even more perhaps than other kinds of genius, religious leaders have been subject to abnormal psychical visitations. Invariably they have been creatures of exalted emotional sensibility. Often they have led a discordant inner life, and had melancholy during part of their career. They have ... presented all sorts of peculiarities which are ordinarily classed as pathological. ${ }^{\text {I }}$

In his twenties, John Humphrey Noyes exhibited exactly the symptoms William James later ascribed to religious genius. Along with showing an intense religious creativity. Noyes often behaved so strangely that his closest friends and family assumed him "a downright madman." 2 In part, this was due to the psychological crises that had come to dominate his college career. Lacking a clear sense of identity, fruitlessly seeking order and security, and frequently depressed. Noyes could not find what he felt society demanded of him: religious certitude, a masculine career played out in the economic marketplace, and carefree and secure social relations. Especially did he resent his lack of control over his surroundings and over himself. This resentment would play a major part in turning Noyes's conversion from a relatively normal, lifegiving experience into a prolonged period of iconoclasm. In addition, the unique rulebreaking nature of Noyes's religious history stemmed from two of his personality traits. Above all, Noyes was nothing if not intellectually honest. He could not accept any statement without proving it to his satisfaction, and he insisted on taking any truth he 
accepted to its logical (no matter how radical) conclusion. Related to this characteristic was his "all or nothing" attitude. Moderation and expediency were unacceptable to him and he had only contempt for half-measures, which he felt would always fail, "as all half-measures must." ${ }^{3}$ He could not accommodate himself to either social or religious traditions and conventions. As a result, he spent the better part of the 1830s stumbling through his life, alternating flashes of brilliance with bouts of nearmadness, until, having broken all the existing rules, he was ready to establish his own. ${ }^{4}$

A concept that goes far toward explaining this rule-breaking phase of Noyes's life has been advanced by Erik Erikson. Not willing simply to assign the actions and experiences of a religiously creative person to "religious genius," Erikson, through clinical observation, developed the idea of a "moratorium." The moratorium is a socially approved period of waiting, a pause between adolescence and adulthood, before the life's work begins. It is a time when old ideas, conventions, and rules can be destroyed (frequently with great mental or emotional difficulty) to prepare the way for new creations. Erikson explains the moratorium in his Young Man Luther, wherein he treats Martin Luther's youthful sojourn in a monastery as just such a marking of time. ${ }^{5}$ Luther's moratorium was a determinative experience in his life: when he emerged from his monastic silence he became "his time's greatest orator, publicist, showman, and spiritual dictator." ${ }^{\text {6 }}$ Equally, the importance of this period for Noyes cannot be exaggerated. He went into it with his new-found religious identity; he came out a social reformer. He began his moratorium with a search for order; he ended it with the realization that he could impose order, first on himself, later on his surroundings, eventually on other people. 
Although this similarity of experience between Noyes and Luther does not extend to the depth or breadth of the religious influence of the two men, it does illustrate the importance of the moratorium for the development of creative, radical ideas. The distinguishing characteristics of the moratorium-previous experience of an identity crisis, a difficulty in simply living in time, a tortured self-consciousness featuring both shame and doubt over one's identity, a shying away from intimacy, and obsessive concentration on familiar work habits ${ }^{7}$-can be as easily distinguished in Noyes's college experiences as in Luther's monastic retreat. For both men, moreover, the moratorium was a particularly risky time; Noyes, himself, frequently sensed that he was losing touch with reality and feared a complete breakdown into insanity. In fact, Erikson notes that this was a common experience. "It is probable that in all historical periods some (and by no means the least gifted) young people do not survive their moratorium; they seek death or oblivion, or die in spirit." ${ }^{\circ}$ Noyes, like Luther, forced himself to survive. Of course, in nineteenth century American society, a monastic withdrawal was out of the question; instead, colleges and divinity schools suited the purpose of the creative youth. Noyes's own moratorium really began with his first conversion and carried through his matriculation at Andover and, later, Yale. He did not begin to emerge from it until after his traumatic "New York experience" in 1834.

With this foundation, the iconoclastic nature of Noyes's religious doctrines became easier to understand. Despite the fact that Noyes covered these events in fine detail in his religious autobiography, they must also be considered in the light of his social history. He was always intimately attuned to the social phenomena of his times, no less in religion than any other area. To understand his social theories, then, one must first consider the religious doctrines in which they were imbedded. 
As a young adult, Noyes underwent two permanent, successive conversions. Whereas the second involved an acceptance of radical Perfectionism, the first was fairly typical of the time, an acknowledgement of "a strong consciousness of the approving presence of God, and a confidence that his grace would lead me into all truth and righteousness." ${ }^{\prime 9}$ This first experience occurred in August, 1831, during Noyes's unhappy law career. He heard that a four-day revival was being planned in Putney, and at first resolved to stay away. Noyes's consuming passion for order and peace was affronted by revivalistic religion, which, as he recorded in his college diary, appeared to be "a sort of phrenzy [sic] to which all were liable."10 His curiosity, and perhaps his desire to appease his mother who "was exceedingly anxious that I should receive the word," overcame his reluctance. However, attendance at the revival exacerbated his uneasiness. When the first converts at the meeting were called forward, Noyes was tempted to join them, but feared that when all the excitement had subsided he would lose his first impressions and thereby expose himself to public ridicule. The daily repetition of this ceremony "destroyed its novelty," and thereby its influence on Noyes's confused emotions. ${ }^{11}$

The end of the revival found Noyes in a tumult of mind, still unconverted. As usual, his health suffered when his mind did. Now he wrote:

In the afternoon I was almost sick with a cold, and stayed at home. I took medicine and went to bed, and when the house was empty and all was still, the thought came suddenly and forcibly into my mind that I never should have a more favorable time for submitting to God. The severity of my cold suggested to me the idea of the uncertainty of life. . . I I then, after some hard thinking, determined to obtain religion, and immediately set about conquering my pride. ${ }^{12}$

In the course of the next two days, Noyes was surprised when he found his anxiety diminishing as he read the Bible; indeed, he became so tranquil he thought he 
was losing the conversion impulse. He was unable to "enjoy" this peace of mind, however. He tried but failed to recover his familiar feeling of despair, and became terrified that he would never be converted at all. But when he was convinced by an "experienced Christian" that his feelings were in fact evidences of true conversion, Noyes finally succumbed to them. Slowly, "light gleamed upon my soul . . dim and almost imperceptible at first, but in the course of the day it attained meridian splendor." His thoughts became "as usual in such cases, ecstatic." ${ }^{n 3}$ Four weeks later Noyes found himself at Andover, studying for the ministry.

His conversion experience was not unique; indeed it was one of thousands in the early 1830s. But its deliberate intellectual style set it apart, because most converts surrendered quickly to the emotional spell of the "phrenzy" that was sweeping across the United States at this time. Noyes later labeled 1831 "the year of revivals," and he was particularly accurate in the case of Vermont. The southern part of that state was in the heart of the "burned-over district," and had already undergone modest revivals in 1819 and $1827 .^{1+}$ By 1831 , the Connecticut River Valley's small, local revivals had coalesced into a major movement, with thousands coming forward to be saved. This "great revival," however, did not exhibit the spontaneity of the earlier enthusiasms, since Congregational, Methodist, and Baptist churches consciously used the mechanism of the revival to increase their membership. ${ }^{15}$ Like Noyes's own personal conversion, this was a calculated affair.

Noyes had another symbolic relationship with the great revival. He represented three important types for which the Vermont revivalists cast their nets: youth, college students, and professionals. The revivals attracted a disproportionate number of youth; during the life of the great revival, 1829-1843, the median age of 
entrance into the Congregational and Baptist churches dropped from the late twenties, to twenty-five, and finally to twenty-two. ${ }^{16}$ Jedidiah Burchard, the most influential revivalist to work in the Connecticut River Valley, made some efforts to attract college students, decrying the "stiffness, formality and aristocracy" that hindered their conversions. ${ }^{17}$ Further, for reasons which are obscure, a large group of professional men, including attorneys, physicians, and especially trustees of banks, insurance companies, and industries (among whom the unconverted Noyes had hoped to number himself), joined churches during this revival. Burchard made a point of ridiculing these wealthy men into accepting conversion and more were persuaded now than in any previous revival. While these converts were far outnumbered by various nonproprietors (those who did not own their means of livelihood), their entry into evangelical churches at this time was unprecedented. ${ }^{18}$

It is not known which revivalist conducted the meeting in Putney which resulted in Noyes's eventual conversion. Burchard, himself, did not enter the field until 1834. Whoever it may have been, his efforts marked a turning point in Noyes's life. Religion gave Noyes the key to his identity he had long been seeking. In Eriksonian terms, a religious identity helped Noyes partially to resolve the role confusion he had experienced in the fifth stage of his psychological development. His desperation over his inability to find a suitable role to play in society was the immediate impetus for his attendance at the 1831 revival; he had had no desire to attend an earlier revival in $1827 .^{19}$ Still feeling his way through Dartmouth in 1827 , he had not yet experienced the total failure of his career identity. Despair pushed him to the 1831 revival-even at the enormous risk of appearing ridiculous in society. He was unwilling to hazard 
completely his weak emotional security; however, his final conversion was accomplished in the safety of his own home.

For Noyes, personally, as for society at large, the Vermont revivals proved to be, in the words of Donald G. Mathews, "an organizing process." They opened the way for him to find "meaning and direction" in his life, to overcome the malaise that haunted his college years. And, for Noyes, as again for the whole society, the impact of the Second Great Awakening had little to do with theological issues. There were personal, psychological, and emotional components to his conversion which transcended any theological or ecclesiastical considerations. ${ }^{20}$

But with his penchant for intellectual honesty, Noyes's long-held religious beliefs were sure to come under scrutiny, especially after he lost the "ecstatic" feelings occasioned by his conversion. His immediate abandonment of his legal career and his new resolution to become a minister, while liberating him from past confusion, impelled him to seek deeper intellectual identification with the religion he had embraced. This was one purpose for his intense religious studies at Andover and Yale. Another reason for going back to school was to devote himself to his new life. In $A$ Man Who Would Be Perfect, Thomas notes that Noyes had now "created for himself an inner world of harmony and acceptance and opposed it to the world from which he had withdrawn. He chose the peace of religion rather than the competition of the market place." 21 Thomas also clarifies the meaning of Noyes's withdrawal from a professional career: it was not a denial of the world for religion; rather, Noyes had "outllanked his father's world and acquired for himself a different and legitimate mode of activity."22 Returning to school, even as a convert, did not make life any easier for Noyes. Andover did not provide the external order he craved. Instead of fulfilling his 
desire to be "a young convert in zeal and simplicity forever," both Andover and, later, Yale, engendered in him anxiety and conflict. ${ }^{23}$ Further, as he pushed himself deeper into religious studies seeking justification for his new religious life, the pressure became unbearable. As previously related, some relief was gained when Noyes took his first tentative steps in his new identity, preaching in New Salem, New York.

Even more important in transforming his life was a major theological discovery he made while at Yale in the summer of 1833. He had long been puzzling over Christ's words concerning the apostle John, in John 21:22: "If I will that he tarry till I come what is it to thee?" Noyes, in this Confession of Religious Experience, emphasized the words that seemed to intimate that John would live until the Second Coming. Since John had lived to somewhere around 70 A.D., it dawned on Noyes that the Second Coming must have already occurred. This idea contradicted the traditional religious beliefs that true Christians would be saved when Christ returned some time in the future, that the day of judgment and the Second Coming would be simultaneous events, and that the coming of the Kingdom of God on earth would require the physical presence of Christ. Moreover, it flew in the face of the contemporary millennarian passion, exemplified by the often disappointed Millerites in their anxious vigils for a Second Coming they believed would happen in the immediate future. ${ }^{24}$

Noyes was not deterred by his "advance into positive heresy." Instead, he followed his old method of study, reading the New Testament through ten times. "I soon perceived that every allusion to the Second Coming in which there was any clue to its time, exactly coincided with the natural inference from Christ's words, viz. that John's lifetime would extend to that event." The accumulated proof overcame Noyes's "fright of novelty." He now "knew that the time appointed for the Second Advent was 
within one generation from the time of Christ's personal ministry." Mature Christianity was born then; "'this world' and the 'world to come' flowed together." ${ }^{25}$ This belief that the Second Coming had already occurred was intensely liberating for Noyes. It resulted in "a great diminution of confidence" in the religion he had learned from his mother and from his professors of theology. And, it was almost-but not yet completely-a declaration of independence from all the mental confusion and strivings which had so oppressed him during his college career.

At Yale, Noyes took another fateful step, forming an association with a "free church" in New Haven which was attempting to conduct a revival. Noyes recalled that, although "they scarcely numbered a dozen . . . I loved their spirit, for I was burning with the same zeal which I found in them ... for the conversion of souls." ${ }^{26}$ By the spring of 1833 , having increased its membership enough to engage a regular preacher, the church hired, on Noyes's recommendation, the popular revivalist, James Boyle. ${ }^{27}$

Noyes had taken an interest in Boyle because both men were now following the path which led from enthusiastic religion to Perfectionism. Immediately after his discovery of the true nature of the Second Coming, Noyes began to drift toward radical Perfectionism. He correctly saw Perfectionism as the logical conclusion of the whole revivalistic movement. The heart of the Second Great Awakening was the belief in free will-that man could choose salvation, and Noyes fully appreciated the significance of Professor Taylor's instruction on this point. But Noyes felt Taylor stopped short of man's true moral ability. He wrote, "If we preach to sinners their ability to repent, and the obligation of immediate submission to God, why ought we not lay to heart our ability to be perfectly holy."28 If predestination was a dying concept in America, and if salvation and its prerequisite, moral perfection, were truly available to all, there should 
be no reasonable barrier to requiring this of all converts immediately. Immediate, perfect holiness was achievable through a conversion experience, such as the apostles had experienced at Pentecost.

Needless to say, most Christians in the United States, and not only the most conservative, found Perfectionism abhorrent. Far from urging converts to try to reform specific faults gradually by following socially approved moral precepts, Perfectionism held that ready-made sinlessness was immediately available to those who had been educated to receive it. A Perfectionist would not need to practice self-control and moderation; indeed, he need have no inhibitions since the Holy Ghost had conferred upon him complete security against further commission of $\sin$. The abolishing of traditional moral restraints-especially in regard to sexual promiscuity-was the most unacceptable aspect of the Perfectionist movement. ${ }^{29}$

Indeed, as Noyes labored with Boyle and his associate, Chauncey Dutton, to bring sinners into the free church, he was overcome with both guilt and shame that he was still a sinner, trying to preach to sinners. He felt that "in searching the scriptures for truths adapted to pierce the hearts of the impenitent, I was found at last pierced and writhing on the points of those very truths myself."30 Secking answers to these disturbing realizations, Noyes read the works of John Wesley on Christian Perfectionism. ${ }^{31}$

During the First Great Awakening a century before, Wesley had advanced the Arminian doctrines that Christ died for all men, and that men can help determine their own salvation. His Methodist Church also preached the importance of ethical purity, evangelical piety, and a "growing in grace"-although total perfection was not humanly possible-which Wesley called Perfectionism. While Methodism was able to make 
inroads among the poorer populations of the south, New England had repudiated the entire concept as an egregious doctrinal error. ${ }^{32}$ Nevertheless, it was an important precursor to the Second Great Awakening, a seed awaiting more amenable conditions before sprouting.

Noyes ended by gently repudiating Wesley. In Bible Communism, he differentiated his brand of Perfectionism from the wrong-headed "Oberlin Perfectionism," by tracing the latter's roots directly to Wesley. ${ }^{33}$ An instructive comparison can be made between the two forms of Perfectionism, in order to understand the absolute, radical nature of the doctrine that Noyes was to espouse. Oberlin College fell under the spell of the greatest of the revivalist preachers of the Second Great Awakening, Charles G. Finney. Finney followed Wesley's lead in discussing the possibility of perfection, ${ }^{34}$ and, like him, hesitated before the idea of human perfectibility. He stopped short of absolute, assured perfection. Instead, he preached that, while no one could achieve perfection, the professing Christian must "aim at being perfect." He painted a picture of the constantly striving Christian who, in "entire conformity of heart and life to all the known will of God," will continually rise toward "richer attainments" of holiness; each step would create in the Christian "more enkindlings of desire, and more intensive struggles to advance. ${ }^{3.5}$ In short, Finney summarized his belief in human perfectibility as "in a word, to be in our measure as perfect as God is. ${ }^{136}$

Thus, Noyes could study under Taylor, read Wesley, and support and appreciate the work of Finney. But his heart and mind were not satisfied by their teachings. It was their failure to believe that man could actually be perfect and could be (through the Holy Spirit) completely assured of salvation, that differentiated Wesley 
and Finney from Noyes. The split between Finney and Noyes would eventually mark the two branches of American Perfectionism in the nineteenth century: Finney's Oberlin Perfectionism and Noyes's New Haven Perfectionism.

Meanwhile, Noyes continued his search for perfection in the company of Boyle and Dutton. Fellowship with Boyle and Dutton created a kind of a family of mutual interests, a situation in which Noyes always felt most comfortable. He found his spirit increasing in strength. Indeed, he and Dutton had a fully sympathetic relationship, and, as Noyes related, "Our hearts were knit together with a love 'passing the love of women. ${ }^{1.37}$ Frequent discussions among the three on the subject of perfect holiness were mutually influential: both Noyes and Boyle converted to Perfectionism early in 1834. Noyes, for almost the first time in his adult life, thought he was happy. The desperation that dogged him before his first conversion had seemingly disappeared. Noyes paused in his religious autobiography to call attention to his state of mind on the even of his conversion to Perfectionism:

I was no longer tormented with inordinate alimentiveness, and other temptations to sensuality. I had conquered my nervous system, which for a long time after my first religious agitation had been morbidly excitable. I could now study intensely, twelve or even sixteen hours in a day, without injury. Preaching, which once would shake and disorder my nerves, had become a delight and refreshment to me. I was constantly cheerful, and often very happy.

To reach this emotional state, however, Noyes had had to exercise a rigid self control. To maintain a cheerful facade he had to rely on "systematic temperance, fasting, exercise and prayer." He would spend a minimum of three hours a day closeted in his room in prayer, "so burdened with spiritual joy, that my body became weak and pined away. ${ }^{138}$ This monastic self-denial was consistent with the Eriksonian moratorium. Erikson adds that the outstanding quality of a person in Noyes's state of 
identity crisis is "totalism, a to be or not to be which makes every matter of differences a matter of mutually exclusive essences; every question mark a matter of forfeited existence; every error or oversight, eternal treason." Erikson explains this attitude "as the sign of a perverted and precocious integrity, an attempt to find that immutable bedrock on which the struggle for a new existence can safely begin and be assured of a future."139

Within a few weeks of his almost being happy, Noyes was again plunged into depression. Once again the folly of trying to save others while he, himself, was not saved overtook him and made him physically ill. He took little food for a week; he saw "immeasurable wickedness" within himself; he loathed his life and wanted to die. ${ }^{40}$ So Noyes's first conversion was not enough; he was ready for another plunge into certitude. Once again, the listless Noyes opened his Bible at random, and once again it answered. The words glowed on the page: "The Holy Ghost shall come upon thee, and the power of the Highest shall overshadow thee; therefore also that holy thing which shall be born of thee shall be call the Son of God." Again and again he reopened the book to read, "And the Lord shall deliver me from every evil work." and "Go, stand and speak in the temple to the people." ${ }^{.11}$

Noyes accepted this as the truth of Perfectionism. Whereupon he: went home with a feeling that I had committed myself irreversibly, and, on my bed that night, I received the baptism which I desired and expected. Three times in quick succession a stream of eternal love gushed through my heart and rolled back again to its source. . . All fear and doubt and condemnation passed away. ${ }^{42}$

Following the biblical dictates, Noyes announced to his free church congregation and to his Yale associates that he did not commit sin, that he was free from sin. However, he was always careful to point out that he did not consider himself perfect to the 
exclusion of improvement or self-discipline. He wrote: "I do not pretend to perfection in externals. I only claim purity of heart and the answer of a good conscience toward God. A book may be true and perfect in sentiment, and yet be deficient in graces of style and typographical accuracy." But even as he experienced the flush of rapture over his conversion, it began to dissolve. He had entered the arena of religious warfare and knew that he had to suffer the consequences. ${ }^{43}$

Still a student at Yale, he fought his first battles with fellow students who "flocked to my room-some to see the 'perfect man,' as they would go to see an elephant or any other curiosity." He very soon wearied of being "a show." ${ }^{+4}$ But his difficulties rapidly compounded themselves. He was expelled from Yale after his professors proclaimed him a heretic; his ministerial license was revoked. His family and friends thought him deranged. Chauncey Dutton would not follow Noyes into fullfledged Perfectionism and departed for Albany.

Most devastating of all was an unresolved attraction for Abigail Merwin, his first convert to Perfectionism. She was a member of the free church at New Haven which Noyes had been trying to convert to his own new Perfectionist belief. Merwin converted immediately upon hearing Noyes's message. This alone may have endeared her to him, but she had other qualities that appealed to Noyes, especially her ability to withstand public ridicule and condemnation: "She had a surprising readiness of apprehension, and facility of communication. Her testimony was bold, and yet modest. Her power of argument, and her position as my first convert, placed her with me in the front of the battle, and in the full glare of the public gaze; and she nobly sustained the trial." In addition, she was related to the church's deacon and to many of the members; her conversion gave Noyes a "stand-point" and eventual ascendancy over the 
church. ${ }^{45}$ With his mother questioning his conversion to Perfectionism, ${ }^{46}$ with Dutton gone, a break with Boyle impending, his former professors and fellow students abandoning him, and fighting mightily for conversions that were too slow in coming, Noyes needed an ally, a companion, if not a lover. In his religious autobiography, Noyes never admits to being in love with Merwin. He was interested in her, and trusted her, but, he wrote: "I was conscious of no feelings toward her but those of calm brotherly love. The idea of marriage never entered my head. . . [Yet] she was undoubtedly the person to whom I was attached more than to any other person on earth.".77 $^{.+7}$

In complete contrast, however, is a letter quoted by G. W. Noyes, which Noyes wrote to Merwin in 1835 , proclaiming his love for her:

In the darkness of the memorable period you arose like a morning-star to my soul. ... Continued acquaintance increased my respect and affection for you, and I confess without shame that I loved you as I never loved another, for reasons which $I$ never saw in any other. ${ }^{48}$

Faced with his turbulent, unresolved emotions, Noyes had to get away from New Haven.

He decided to go to New York, for the purpose of "clearing Perfectionism of the disreputable mysticisms and barbarisms which had begun to discredit it." ${ }^{49}$ Noyes was referring, of course, to the rumors-many of them substantiated-of free love among New York Perfectionists. In central New York state various Perfectionist cults practiced "Spiritual Wifery," which, while it may not have led to actual promiscuity, certainly impressed outsiders as such. Moreover, some of these groups committed even greater religious heresy by denouncing the gospels and refusing to follow any authority but immediate inspiration. ${ }^{50}$ These types of Perfectionists deeply offended Noyes's 
strict sense of propriety and order. The also were responsible for the treatment he was receiving from society, and for his isolation. He had every intention of establishing his control over them, indeed, over all eastern Perfectionism.

Noyes never accomplished his goal. He did travel to New York City in the spring of 1834 , but upon arriving, was devastated by what a later generation would call a nervous breakdown. His "New York experience" was the lowest point of his moratorium, if not of his life. For the modern student it is a very instructive episode for two reasons. First, it offers remarkable insights into Noyes's mind as he struggled finally to root out of his soul the dying past. It was a manifestation of the riskiest kind of moratorium, which Erikson described as the efforts of creative men to "starve themselves, socially, erotically, and last but not least, nutritionally, in order to let the grosser weeds die out, and make way for the growth of their inner garden." 51 Secondly, the "New York experience" illustrates Noyes's intimate ties with his own times. Even while groping to find his way out of the worst depression of his life, Noyes was drawn, not to the Bible, but to contemporary self-help movements. He tested their efficacy on himself, by following the contemporary ideas to their logical conclusion. He ended by discarding them all, preparing the way for his eventual recreation of society.

Noyes came close to a total break with reality when all his past anxieties came home to roost at the same time. With his tendency toward "totalism," he saw the world as made up of objects either totally good or bad. He saw himself as totally good, but those external objects that threatened him were totally bad. In New York, they appeared to be merging with him. The hostility Noyes usually turned outward against the bad was now turned inward against himself. ${ }^{52}$ In his religious 
autobiography, Noyes recalled that he felt that, "I myself was Lucifer, the fallen son of the morning. I submitted to this impression with a struggling resignation to the decree which doomed me to eternal perdition." ${ }^{53}$

Physical symptoms assailed him at once. He saw himself enveloped in "a strange, murky spiritual atmosphere." He suddenly felt that he was dying, suffering such "suffocating pressure on [his] lungs" that he put his room in order and "lay down to die." He was surprised to note that resignation and acceptance of death caused the pressure to pass and he "returned to life."

Other physical torments Noyes endured included loss of appetite and aversion to sleep. After days of mental anguish and physical labor, he would be assailed by "a horror of sleep," and wander New York streets all night, collapsing for a few minutes on doorsteps or benches. This continued for three weeks. ${ }^{55}$ This physical torture added to his mental derangement to produce visions. Most traumatic for him was a vision of Abigail Merwin as "Satan transformed into an angel of light." Seeing her standing on the "pinnacle of the universe," looking like an angel, while hearing a voice pronounce her to be Satan, gave him the resolve to cast her off "as one accursed." 56

The first contemporary reform movement that Noyes experimented with in New York concerned the plight of what he called the "abandoned men and women" who were outcasts from the new economic system. Noyes would later understand that many people could not remake their lives to fit the new rhythms, customs, and expectations of industrializing society. ${ }^{57}$ The economic outcasts, along with those dislocated by pervasive poverty and hopelessness, often ended up in New York. Noyes came face to face with these people, deliberately secking them out on his nightly wanderings "into the vilest parts of the city." Once again pitting himself against his 
fear of destruction he "went alone at midnight into streets which ... were dangerous even in the daytime." He tried to preach Perfectionism to these "abandoned men and women"; he gave them Bibles and money when he had any. ${ }^{58}$

Although he sympathized with their problems, and did not forget them, Noyes had, in 1834 , no social or economic theories to account for their misery or to relieve their burdens. Instead, he completely shared the belief current in the first half of the nineteenth century that self-control was the answer to the confusion and dislocation caused by rapid social changes. For Noyes, Perfectionism represented the ultimate in self-control, sinlessness through personal choice. This is what he preached, without success, to the poor in New York. Self-control would remain at the heart of Noyes's social theories, even as they advanced in practicality and realism.

In New York, Noyes also practiced contemporary ideas on himself. He surveyed various self-control, self-help schemes, and though he did not discard them all, he saw them as insufficient. For instance, he was struck with the impression "that flesh-eating is a barbarism which will be abolished in the kingdom of God." Although he firmly believed in the crucial role of food in the overall linkage between mind, body, and spirit (as did the renowned prophet of nutritional and bodily self-control, Sylvester Graham), he parted ways with Graham by excluding fish from vegetarian prohibitions. ${ }^{59}$

He also scrutinized his long-held belief in strict dietary limitations. He decided to follow a "course of medical treatment" for his many bodily ills by eating and drinking exactly what he craved. He found that he preferred the strongest foods, such as cayenne pepper. As a result, he reported: 
a permanent and highly favorable change of the tone of my system. I had been previously, for a long time, dyspeptic in my habits, and necessarily scrupulous about the quality of my food. After the tanning process . . my stomach became a very peaceable member of the corporeal community. ${ }^{60}$

Noyes examined, too, his firm advocacy of the temperance movement. When he converted to Perfectionism he felt obliged to renounce the temperance movement as a superficial notion of morality that should be subsumed in an overall sinlessness. But in New York it occurred to him that his mind and feelings were "still in some bondage to the habits and influences of my former life." The question cross his mind, "Can I trust my passions, desires, propensities-everything within me which has heretofore been governed by the rule of the world and by my own volitions-to the paramount sway of God's spirit?" Could he trust God for morality? He quoted Luther to himself, to the effect that the strict prohibitions of the Old Testament should be deliberately defied in order to proclaim true liberty of the Christian. So, Noyes deliberately indulged in ardent spirits to prove his freedom from the old law, and also because wine was biblically prescribed for "him that is ready to perish . . . and those who be of heavy hearts." The biblical references cleared his conscience, and gave him a "freedom from the petty tyranny of fashionable morality." He found that he was able to remain temperate "without the help of pledges or the influences of human combinations." ${ }^{n t}$

Noyes went beyond simply trying and discarding contemporary cures for his mounting tension. So anxious was Noyes to take control, to overthrow outside efforts to diminish his sense of control that, during his "New York experience," he experimented with pure nihilism. He let go of everything he had positively known. His mind turned all scientific concepts "topsy-turvy"; he saw the Copernican system as 
false, the Bible as a "monstrous imposition," and Jesus Christ as "the prince of the devils." He fell under the "darkness of atheism."62

This was the bottom. Slowly Noyes began to pull himself back into the light, helped immeasurably by several positive external events. His family and friends came to his rescue with money, which had been a constant worry in New York. He even found a New York minister who, far from castigating him for his Perfectionism, listened to Noyes's views affably, courteously, even favorably. Noyes realized he was not as isolated as he had thought. Even his physical infirmities began to heal. All during his stay in New York his feet had been inflamed and ulcerated-he could hardly walk for the pain. But Noyes followed an "instinctual" impulse to "seek the salt water and bathe," which completely healed his feet in one day. ${ }^{63}$ Noyes's body, always a symbol for his mental condition, indicated his new understanding that his life was "fire-proof. .. Hell has done its worst, and yet I live. ${ }^{164}$

He summed up his moratorium this way: "The effect of this mental overturn was permanent. It completely emptied me, for the time being, of all the theories which I had previously stored up. I could hardly tell afterward what I believed on any subject, till I had investigated it anew. ${ }^{65}$ He had achieved self-control by passing safety through his self-imposed hell. He was ready to remake society in his image; he was now convinced that he had been anointed by God to do this. Noyes always identified closely with the suffering Christ and the apostle Paul, and this belief was solidified by the "New York experience." He believed, as one of his earliest followers later wrote, that he "bears the same relation to the church of God at the present day that Moses did to the Israelites and that Paul did to the church of Christ in his day, namely, that God has made him a prince and a Leader." ${ }^{\text {"6 }}$ 
Armed with this commission, Noyes passed out of his moratorium, ready to found the Kingdom of God on earth. He had come to grips with his conversion, his heresy, and his Perfectionism. He had broken all the rules and conventions of his time; he had cleared the way for new ones of his own making. He wrote his mother in 1835 :

So far as I am concerned, the work of bloodshed is finished. The God of battles has given me the liberty for which I have long been contending. I am as free for God's service, as if I had never known father, or mother, or brother, or sister; . . . I have learned that God has not kindled a fire in my brain to burn me up, but to warm me; and when the fire goes beyond its proper office, I throw water on it. . . . I have begun to discover that I am fearfully and wonderfully made; that $I$ am a glorious kingdom in myself, a kingdom that has long lain in ruins through misrule and darkness, but is yet capable of glorifying its maker and rendering a rich revenue of blessedness to its sovereign. When I have completely ascertained the limits, character and resources of this kingdom, quelled all the rebellions which waste it, and secured the revenue which is due to its king, I shall be prepared to assist other sovereigns in like enterprises. ${ }^{67}$ 


\title{
CHAPTER V
}

\section{SOCIAL PERFECTION}

\begin{abstract}
As a man who has passed through a series of passional excitements, is never the same being afterward, so we insist that these socialistic paroxysms have changed the heart of the nation; and that a yearning toward social reconstruction has become a part of the continuous, permanent, inner experience of the American people. ${ }^{l}$
\end{abstract}

Noyes was about to enter a period of peace; not external peace-his message would always keep him at odds with the world-but he slowly acquired peace of mind, self-assurance, and the security of religious certainty. Having come to understand that he had a divine commission to establish the Kingdom of God on earth, he now began a twofold mission. First, he had to convince people of the truth of his kind of Perfectionism, leading them to accept his commission to found God's earthly kingdom. Secondly, and by implication, Noyes had to puzzle out exactly that form his new godly society would take.

Noyes's ideal society would come to be based entirely on the doctrine of Complex Marriage, which involved a rejection of monogamous marriage in favor of the freedom of all true believers to love each other spiritually and physically. Complex Marriage was a sexual theory so revolutionary in nineteenth-century America that its thirty year existence in actual practice must be seen as one of the anomalies of that time. Only the hedges that Noyes placed against its degeneration into "free love" found made Complex Marriage possible. The period from 1834 to 1838 found Noyes transforming himself into the confident, creative leader who could conceive of a socicty 
based on Complex Marriage. But this outcome was hardly foreseeable in the immediate aftermath of the "New York experience."

At the request of the Noyes family, James Benjamin, the former deacon of the free church at New Haven, Abigail Merwin's brother-in-law, and another early convert to Perfectionism, went to New York to rescue John Humphrey Noyes. Returning to Putney in June, 1834, Noyes rapidly improved. The security of his home and family had always been necessary to his recovery from bouts of depression. In addition, since his two conversions, he had become more secure in his own mind about sin and his relation to God. Looking back on his recent "New York experience," he realized that the only truths on which to build a life were "what we positively know." Doubts, guesses, and speculations over conflicting ideas have to be discarded as quickly as possible or turned into certainties. Noyes wrote, "The true method of mental economy is to look over the whole mass of our thoughts, select out all that we absolutely know, and keep that by itself, accounting it our specie-basis." He had discovered that his "mental capital" of secure knowledge was "the only way to get and keep a sound mind."2 Knowing that he now had control over himself, Noyes was able to find a large measure of serenity at home in Putney.

Two dark clouds loomed on his mental horizon, however. The first was the necessity of dispelling his family's notion that he was crazy. To prove that he was sane and in control of himself, he kept very much to himself and made meditation his "principal business." ${ }^{3}$ So careful did he become not to give any impression of madness. nor to offend any religious sensibilities in Putney, that he confessed to his brother, Horatio, that he saw himself as "living under an embargo." 
Noyes's second problem was more pressing and more tormenting: he still did not have a normal career whereby he could earn enough money to support himself. He knew he had been called to be a Perfectionist leader; he had no doubts about that. There was also no doubt that this career was a financially losing proposition. Since his period of depression in New York, money had become an all-consuming worry. $\mathrm{He}$ had always lived in the financial security provided by his well-to-do father. In fact, he cited "pecuniary circumstances [which] were favorable to my independence" as one of the factors in his readiness to accept Perfectionism even though he lost his license to preach. 5

It was not a matter of money; it was a matter of dependence. Through religion Noyes felt he had achieved "the strength of manhood." ${ }^{\text {" }}$ Being dependent on his father for money, however, ruined his sense of independence. Noyes now refused to accept any more money from his family until they accepted his Perfectionism and his leadership. Writing from New Haven in late 1834. Noyes told his father that "if you are not interested in the object for which I live, I cannot ask or expect you to assist me." ${ }^{\prime 7}$ A month later, he explained to his mother that he would not move home because he would be merely a dependent there, "living upon" a father who would not accept the truth of his Perfectionism. ${ }^{8}$ Noyes clarified his feelings in a subsequent letter to his sister Elizabeth:

As to want of money, while God withholds it I want it not. Yet my present situation ... is one which I should once have counted necessitous. Fifty dollars would increase my external comfort. ... Though I am here [in New Haven] in a state of dependence on those who are not my kindred according to the flesh, I am well content, for they give me thanks and love with their money and sustenance. If you dislike the idea of my dependence on others, I ask, Where will my dependence be more servile, here or at home? Here I am writing for the press and preaching. At home, as you 
well know, I could do comparatively nothing. And am I less in a state of dependence on others at home than abroad? ${ }^{9}$

To legitimize his career as a Perfectionist leader, Noyes believed that he must first establish his dominance over his family. It was vital for his self-esteem that his family recognize his self-created identity. Noyes imagined his identity as the prize in a pitched battle between them and himself. He easily convinced Harriet, Charlotte, and George (three of his younger siblings) to accept his divine commission. However, he had a more difficult time with his older sister Joanna. Although he admired her "masculine, independent temperament," Noyes castigated her for her pride and selfwill. ${ }^{10}$ In the words of their sister, Charlotte, "a battle-royal ensued" between the two, but John conquered Joanna's spirit and she, too, ended by converting to Perfectionism. ${ }^{11}$

That trial was as nothing compared to the battle with his mother. Polly Noyes was, and had always been, the dominant parent in the family. Squire Noyes had lately become an even weaker figure: he was in his seventies, in poor health, and drank immoderately. Thus, he no longer represented a challenge to Noyes. Polly Noyes did. She refused to give in to her son's declaration that all who followed his religious persuasion must take a subordinate place to him. She wrote years later:

How could I, who had so long been the acknowledged head of the family, consent to give up the control with which I believed God had invested me? How could I see my judgement overruled in all the family arrangements-who should come into the family and who not, whether or not George should go to college, even in the preparations for the table.

She detailed the "cold reserve" with which she was treated by the family members who had agreed with John's assumption of the leadership role. Her home became "a furnace of fire." 12 But, like her children, she finally broke down in 1839 under the 
unrelenting pressure from her son. Over the years, her will frequently reasserted itself en famille, but to the public eye-and John Humphrey Noyes was always conscious of how he and his followers appeared to the public-Polly Noyes was counted as a supporter of her son's endeavors until she died at Oneida in 1866. Thus, by the slow, grinding process of wearing down the wills of others, Noyes was finally able to accomplish the fifth level of the Eriksonian developmental scheme, identity. He had overcome his role confusion through his two religious conversions and public acknowledgement (albeit often forced) of his leadership.

Although he claimed not to be worried about his financial situation per se from 1834 to 1838 , trusting that God and fellow Perfectionists would provide, Noyes's letters indicate otherwise. In December, 1834, he contemplated leaving New Haven to look for employment and support. The local Perfectionists were neither numerous nor wealthy, and Noyes felt constrained from asking them for support. ${ }^{13}$ But, as he wrote his mother in 1835, "I found that the love of independence was one of the strongest cravings of my nature, and that this could never be gratified till I earned my bread as other people do." In "seeking [his] fortune" he had been working for a debt-collector; he was soon to undertake a survey of the town of Milford, Connecticut. He also considered teaching. He added, hoping his family "will all have a hearty laugh over it," that his head was now full "of Yankee notions about money-making and economy, and [he had] become a great admirer of Dr. Franklin." In a more serious vain, Noyes said, "I have learned that logic is worth more than poetry, and matter-of-fact industry more than building air castles." ${ }^{14}$ Noyes did not further describe these notions of moneymaking; he certainly never instituted any at this period, although his "Yankee" ideas would burst forth with astounding success at Oneida. 
Nevertheless, he was always able to come up with capital when he needed it. When he started a newspaper called The Witness in Ithaca in August, 1837, he relied chiefly on the contributions of local Perfectionists and on the large list of subscriptions which he had requested his family to develop. But the final step in securing both his financial and psychological independence was taken when he made the acquaintance of a wealthy, unmarried Perfectionist, Harriet A. Holton. ${ }^{15}$

Holton had been converted to Perfectionism after reading a tract written by Noyes and hearing him preach. Upon receiving the first number of The Witness Holton sent Noyes a "love-token" of eighty dollars. Her love surpassed that of a disciple for a religious master, for she had met Noyes at least twice and had confessed herself enthralled by his message and his preaching. In fact, she had once dreamed of marriage to Noyes, but decided that "I should as soon think of marrying the morning star. $^{\text {"16 }}$ For Noyes, however, Holton offered only crucial financial support and the enticing prospect of an unquestioningly loyal follower. Although Holton and Noyes had very much in common, including wealth, well-connected Vermont families, a large number of mutual friends, and a total commitment to Perfectionism, Noyes felt himself still attached to Abigail Merwin.

Earlier, upon leaving New York after his trying experience there, Noyes had been surprised to find that Abigail Merwin had been traveling with her brother-in-law, and had even voyaged home on the same boat with him and Noyes. Yet, she had kept herself hidden from him. Noyes never found out why, ${ }^{17}$ but while in Putney he heard some devastating news that could have explained her behavior. In July, 1834, he received a letter from Chauncey Dutton announcing that Abigail Merwin, along with James Benjamin and his wife, and other of Noyes's early converts to Perfectionism in 
New Haven, had recanted their conversions and had rejoined the free church. Dutton pointed out that the motivation for this "apostasy" was the guilt felt by some of the erstwhile Perfectionists that they had committed $\sin ^{18}$ Upon hearing the news, Noyes tried to fathom the reasons for such a "stunning disaster." He imagined that perhaps reports of his insanity and the "discredit which my unfashionable behavior brought upon the cause at this period, doubtless contributed to dishearten the more timid believers." Further, Noyes felt that Merwin had been persuaded to abandon Perfectionism by her relatives, who related stories about "certain abominations said to have been practiced in the meetings of Perfectionists, such as exposing themselves naked, etc." ${ }^{19}$

Noyes was shocked, but it was a measure of his new self-control that he did not fall into another depression; instead, he acted. In an attempt to recoup some of his losses, Noyes returned to New Haven late in July, 1834. He knew that Merwin was there, but for six months was too shy to approach her. On business, he would pass her house every day. ${ }^{20}$ One day, Noyes was turning a corner and met Merwin face to face; he could say nothing except for a hurried greeting. Finally, after a year of this fruitless behavior, Noyes summoned up the courage to call on her. She was polite, but refused a reconciliation. Her father, moreover, distrusted Noyes and refused to let him see her again. He never did. ${ }^{21}$

Nevertheless, Noyes had convinced himself that she belonged to him. As a result, the news of her engagement to another in September, 1835 was, in the words of G. W. Noyes, "a dagger at Noyes's heart."22 Noyes believed that her request that he act as her religious pastor instituted an irrevocable relationship which impose[d] duties on me that are wholly irrespective of her subsequent choice. If God placed me in that relationship to her and she accepted it, she cannot break it up by a mere change of her feelings and will ... I 
acted faithfully as Abigail Merwin's pastor. I held onto her and sought her not for my own pleasure but as a lover of her soul. ${ }^{23}$

In December, he wrote a long letter to Merwin to communicate these pent-up

feelings and to advise her of another vision he had had of her while in Prospect,

Connecticut, preaching Perfectionism:

At length in the midst of another series of sufferings at Prospect I saw you again clothed in white robes, and by the word of the Lord you were given to me. My assurance that you would be mine was so strong, that I scrupled not to declare it openly. At the same time I was instructed as to the place which the marriage relation will hold in the coming dispensation. . . . Thrice like Paul I besought the Lord that you might depart from me, and thrice like him I was refused. I know now that my love for you is the gift of God, pure and free, above all jealousy and above all fear. I can say of you to my Father: "She was thine, and thou gavest her to me; all mine are thine, and thine are mine." . . . Still $I$ have the right and the will to love you as the workmanship of God, as my sister, as my neighbor, as myself. I ask no more till God shall make you know that he has joined us in an immortal marriage, and that what God hath joined together, man cannot put asunder..$^{24}$

Thus, Noyes's desire for Merwin resulted in the earliest formulation of his basic social philosophy, Complex Marriage. This doctrine would underlay all the work he would do for the rest of his life. In his first vague enunciation of his most radical social idea, Noyes held simply that in the "new dispensation" of Noyesian Perfectionism, spiritual marriages exist and man cannot sunder. One such was Noyes's with Merwin.

Complete development of this idea came with the subsequent shock of Merwin's marriage in January, 1837. This event served as the catalyst for his final delineation of Complex Marriage. The full doctrine appeared in a letter he wrote to his friend and fellow Perfectionist, David Harrison:

I will write all that is in my heart on one delicate subject, and you may judge for yourself whether it is expedient to show this letter to others. When the will of God is done on earth as it is in heaven there will be no marriage. Exclusiveness, jealousy, quarreling have no place at the marriage supper of the Lamb. God has placed a wall of partition between man and woman during the apostasy for good reasons; this partition will be broken 
down in the resurrection for equally good reasons. But woe to him who abolishes the law of the apostasy before he stands in the holiness of the resurrection! I call a certain woman my wife. She is yours, she is Christ's, and in him she is the bride of all saints. She is now in the hands of a stranger, and according to my promise to her I rejoice. My claim upon her cuts directly across the marriage covenant of this world, and God knows the end. ${ }^{25}$

That every saint's-read, Noyesian Perfectionist's-wife was every other saint's wife was as revolutionary a social scheme as could have been devised in the 1830 s. But Noyes had at this time no plans for actually practicing Complex Marriage. It would take years before his airy notion that all saints were married to all saints, not only spiritually but physically, had accumulated enough corollary doctrines to regulate it and remove from it any taint of "free love." Further, some restriction over the practical consequences of Complex Marriage-large numbers of offspring-had to be devised. The development of a fully operational system of Complex Marriage that would endure over thirty years was to be Noyes's greatest achievement.

Noyes's success was made possible by the erection of two vital boundaries to Complex Marriage. The first limitation concerned the overall management of the system. Regulating competition among sexual partners, ensuring that all saints (even the old and unattractive) had a fulfilling role in the central practice of their society, instituting manners and customs surrounding communal sexual relations, and inhibiting the formation of "exclusive," selfish attachments between partners were the first problems Noyes solved. Over the years he had elaborated a "law of fellowship," which held in essence that those wishing to improve their spiritual standing should associate with their spiritual betters. This Noyes came to call "ascending fellowship." "Descending fellowship" was a "state in which a person loves those who are below him in spiritual life, so that the drawing of the fellowship is downward." Ascending 
fellowship was, of course, always preferable, but Noyes understood that when the spiritual betters associate with those farther down the fellowship ladder (as they must in order to draw them upward), the effects of that necessary descending fellowship must be regulated.

The only principle on which descending fellowship can be justified is that it is sanctioned by the superior, that it is identified with the ascending fellowship and gets its authority from it. All true, legitimate descending fellowship carries with it the inspiration of the superior. ${ }^{26}$

Now, this law of fellowship would circumscribe all sexual relations at both the Putney and Oneida communities. A person's partner must be higher in the ascending fellowship; the superior person must be immune from any downward tending influence from the lower person, and especially must be immune from any tendency toward exclusive attachments. In actual practice, it was felt that the older Perfectionists were higher in fellowship than the younger, so that the older members would usually initiate sexual relations and induct the new and young members into the system of Complex Marriage. Thus, the older Perfectionists, far from being left out, occupied important places within Complex Marriage. Being at the top of the fellowship ladder, Noyes was able to control and regulate the system himself, or appoint lieutenants to do so. ${ }^{27}$

The second important corollary to Complex Marriage was a principle that Noyes developed after his own marriage in 1838. When his wife suffered four stillbirths in the first six years of marriage, Noyes devised a method of birth control he called "Male Continence." As he later explained in Bible Communism, Noyes isolated two components of sexual relations, the "amative," or love-related, and the "propagative." God intended "amativeness" to be the primary function of sexual relations since $\mathrm{He}$ instituted love-making during the period of innocence in the Garden 
of Eden. "In the primitive position of the sexes (which is the position of the sexes in Christ), each reflects upon the other the love of God; each excites and develops the divine action in the other. Thus amativeness is to life, as sunshine to vegetation." 28 In order to emphasize this aspect and to decrease the procreative function-which in turn would protect the woman from the curses of involuntary procreation and the man from a wasteful drain of his life energy-Noyes advocated coitus reservatus, or intercourse without ejaculation. Having practiced it himself, Noyes felt that Male Continence would come naturally and easily to spiritual men, who had discovered that a man's greatest glory was to control himself. ${ }^{29}$ The responsibility for birth control was the man's, Noyes believed. Contrary to contemporary belief that the woman was the more spiritual and morally pure sex, he held that "woman is comparatively passive, and man is active; and the active party should be responsible for the passive." In the fellowship of men and women, the man was ascending, the woman usually descending. ${ }^{30}$ It is important, however, to note that Noyes did not accept the "central tenet" of nineteenth-century sexual ideology, the idea of female passionlessness. ${ }^{31}$ As he showed in his discussions of amative intercourse, the woman as well as the man was able and entitled to enjoyment, which would be enhanced by eliminating all the hazards of pregnancy. Noyes wrote that after initiating the practice of Male Continence with his wife his own "enjoyment was increased," and his wife's "experience was very satisfactory, as it had never been before." ${ }^{32}$

Noyes was unique among contemporary reformers in understanding the importance of sex. He believed that, next to reconciliation to God, mankind had no greater task than to free sexuality from shame and guilt and thereby link the sexual impulse to salvation. 
The only hopeful scheme of Moral Reform, is one which will bring the sexes together according to the demands of nature. The desire of the sexes is a stream ever running. If it is dammed up, it will break out irregularly and destructively. The only way to make it safe and useful, is to give it a free natural channel. ... The practice which we propose will advance civilization and refinement at railroad speed. The self-control, retention of life, and ascent out of sensualism, which must result ... will at once raise the race to new vigor and beauty, moral and physical. And the refining effects of sexual love (which are recognized more of less in the world) will be increased a thousand-fold, when sexual intercourse becomes a method of ordinary conversation, and each is married to all. ${ }^{33}$

However, this elaboration of Complex Marriage was still far in the future. For now, all Noyes had was a radical idea, committed to writing, prompted by his unrequited love for a married woman. David Harrison held onto Noyes's letter for several months, but finally feeling that God would not allow him to suppress it any longer, sent it to T. R. Gates in Philadelphia. Gates was the publisher of a Perfectionist paper called The Battle-Axe and Weapons of War. Interested in Noyes theory, he published the letter in August, $1837 .^{34}$ The storm raised by this "Battle-Axe letter" and Noyes's determination both to defend himself against charges of licentiousness and to continue to promote Complex Marriage, triggered Noyes's career as a social reformer.

Fortunately, in August, 1837, he had at hand his favorite vehicle for defending and explaining himself. He had just commenced publication of The Witness. This paper was not Noyes's first venture into journalism. Earlier, in 1834, leaving Putney for New Haven to recall Abigail Merwin from her apostasy, Noyes had joined with James Boyle to fulfill a long-held desire to start a Perfectionist paper. With the establishment of Noyes's first paper, called The Perfectionist, another piece of his lifelong puzzle over his identity, over his career, fell into place. Noyes loved writing; he was good at it and found that it was the most efficient means of disseminating the 
ideas that churned in his mind. The six months during which Noyes worked on The Perfectionist were, he wrote, "one of the most interesting seasons of my life." He learned how to write for the public, to follow instead of forcing the flow of thought, to await the "moment of inspiration." Writing gave him much personal pleasure and profit all his life. ${ }^{35}$ Personally, writing and publishing were to Noyes an important way of controlling his environment. Further, his confidence in the power of his ideas joined with his faith in the press to reform society. Like so many advocates of so many causes in the nineteenth century he started a newspaper. ${ }^{36}$

As in so many other areas of his life, Noyes was a true creature of his times in believing in the power of the press. The growth of all types of newspapers between 1800 and 1840 was phenomenal. The number of all papers increased almost six times in these years: from 235 in 1800 , to 371 in 1810,512 in 1820,861 in $1828,1,258$ in 1835 , and 1,404 in $1840 . .^{37}$ One of the features of this period was a growth of religious newspapers that was so rapid and widespread that in the large cities religious weeklies competed successfully with secular papers. ${ }^{38}$ Noyes was thus riding the crest of a huge wave of publication in the 1830s. The extreme energy of Amcrican journalism in the period was due as much to the proliferation of newspapers and periodicals-with thousands of papers begun and dying before they could even be counted-as to the opinionated state of this journalism. Almost every paper promoted an issue, a party, or a reform; "Neutrality is this country and this age is an anomaly-it is a hybrid state," wrote one paper in $18444^{39}$ A rising readership eagerly supported this journalistic explosion. A generally high literacy rate, even among the poor, running around 91 percent from 1833 to 1860 , accounted partly for this. ${ }^{40}$ Like no doubt hundred of publishers of small religious and reform organs, Noyes had disciples 
who were unable to pay the subscription price to The Witness but were still avid readers. ${ }^{41}$ Other significant factors in the great increase in newspaper and periodical readership was the advent of oil lamps in the 1830 s and 1840 s, the overall decline in the price of newspapers due to improvements in presses and paper making machinery, and reduced postal rates. Especially important for the reform and religious press was the dramatic increase in women readers of newspapers in this period. ${ }^{42}$ Noyes flourished in the congenial soil of nineteenth-century journalism; at one time he summarized his life's work as "see[ing] that God has a Press." ${ }^{43}$

Noyes needed a forum that he alone could control. He and Boyle quarrelled continuously over the articles they wrote for The Perfectionist. Boyle only reluctantly allowed Noyes to publish articles airing his new view of the Second Coming. He also argued against Noyes's sense of complete security in sinlessness, preferring a more Wesleyan approach of striving toward perfection. Boyle shared the views of many "New York Perfectionists." This large body had been among the first subscribers to the paper, but, like Boyle, had trouble accepting Noyes's "New Haven Perfectionism." In writing to withdraw his subscription, one New Yorker called Noyes's paper "The Delusionist. ${ }^{144}$

After six months, Noyes left the paper to Boyle and departed amicably. His purpose in leaving New Haven was to make "a trial of the respective strength of the two forces [the New York and New Haven branches of Perfectionism] which seemed to be coming to a collision. ${ }^{45}$ With this decision, Noyes embarked on a three-year period of wandering up and down New England trying to convert all declared Perfectionists to his views. Above all, this required complete submission to Noyes's leadership. Noyes also insisted on doctrinal purity through acceptance of his stand on the Second 
Coming, of the doctrine of "Security" (in complete freedom from sin), and the strict control of all sexual practices to counter the reputation for free love that dogged all Perfectionists.

The importance of this latter point was forcibly driven home to Noyes by an incident that occurred in Brimfield, Massachusetts in February, 1835. Noyes and a fellow Perfectionist, Simon Lovett, ${ }^{46}$ found there a very enthusiastic group of Perfectionists who, under the guise of sinlessness, took various forms of social liberties between the sexes. Noyes at first suffered these "attentions," feeling that they were just innocent evidences of the popularity of his preaching. But he began to suspect them as dangerous when a young girl kissed him.

That night, while on my bed in prayer, I got a clear view of the situation, and I received what I believed to be "orders" to withdraw. I left the next morning alone ... and took a bee-line on foot through snow and cold-below zero-to Putney, sixty miles distant, which I reached within twenty-four hours. ${ }^{47}$

Noyes was lucky that he left when he did. Within two days the Perfectionist excitement in Brimfield increased until it finally "assumed a social and fanatical form." Two local girls entered Simon Lovett's room at night with the intention of demonstrating the triumph of the spirit over the flesh. But, as Noyes succinctly stated later, "as usually happens in such presumptuous experiments, in the end the flesh triumphed over the spirit. The scandal was overwhelming." ${ }^{n 8}$ Indeed, this incident, soon called the Brimfield "bundling," reacted with the known fact that Noyes was a leading Perfectionist, to tar permanently his reputation. Despite the fact that he was not there during the "bundling," despite the fact that he forever afterward condemned free love in any form, despite the fact that his well-publicized sexual theories were quite regulated and controlled and almost-to use an anachronistic term-Victorian, 
Noyes would be accused to the end of his life of advocating and promoting licentiousness. ${ }^{49}$

Noyes was successful for a while in bringing the unruly New York Perfectionists under his domination, but this success was tempered by the inherent antinomianism of Perfectionism. Small local groups tended to splinter into even smaller units without leadership or doctrinal unity. Nevertheless, Noyes exerted his influence in New York, eventually having more followers there than in his own home state. The Burned-over District of New York proved to be the "proper home" of Noyesian Perfectionism. ${ }^{50}$

One of the keys to Noyes's achievements in New York was his second journal, The Witness, which he founded in Ithaca, New York, in August, 1837. Noyes later explained, "I went [to Ithaca] for the purpose on the one hand of starting the paper and the kingdom of God in the center of New York State, and on the other of pursuing and confronting Abigail Merwin, who had deserted her post as my helper. ${ }^{.51}$ However, almost simultaneously with the first issue of The Witness, the "Battle-Axe letter" was published. Most subscribers illustrated their moral outrage over Noyes's sexual theory by immediately withdrawing their financial support. Nevertheless, Noyes stubbornly carried on with the paper. In this respect, the "Battle-Axe letter" proved to be a blessing in disguise, for it forced Noyes to think through the idea of Complex Marriage and to limit and clarify it. The clearest explanation of this doctrine was made in a letter Noyes wrote "to the editress of The Advocate of Moral Reform" in April, 1838. That newspaper, located in New York City, had denounced the "BattleAxe letter" by calling Noyes`s opinion a "dangerous and seductive heresy ... [a] master-stroke of satanic policy [which] opens a floodgate to every species of 
licentiousness . . a refinement of wickedness which puts [the] papacy to the blush..52 Noyes replied with a calm, biblically-based response to these charges:

1. I believe that marriage does not exist in heaven.

2. I believe that the will of God will be done on earth as it is done in heaven; consequently that a time will come when marriage will not exist on earth. . . .

4. I believe that in the heavenly state, which is the hope of our calling, the Holy Spirit takes the place of written laws and arbitrary ceremonies in the relation of the sexes and all other matters.

5. I do not believe that any have attained to that state who are now on earth.

6. I believe that such as make these doctrines a cloak of licentiousness are wholly ignorant of the true nature of the doctrines and will share the doom of Sodom and Gomorrah. ${ }^{53}$

The "true nature" of Complex Marriage was control, the repudiation of the selfish, exclusive possession of persons, and the rescue of sexual relations from the emotionally charged state of modern society to the calm naturalness of divine intention.

The marriage supper of the Lamb is a feast at which every dish is free to every guest. . . . In a holy community, there is no more reason why sexual intercourse should be restrained by law, than why eating and drinking should be-and there is as little occasion for shame in the one case as in the other. ${ }^{54}$

Quite probably, too, as Thomas notes in $A$ Man Who Would Be Perfect, Noyes's concept of the sharing of wives had a defensive quality about it. ${ }^{55}$ Noyes looked upon emotional romantic love much as he did the "phrenzy" of emotional revivalism. He wrote in later life that falling in love was a "kind of fatality-something that people fall into as a man walking in the dark might fall into a pit or into the jaws of a wild beast-there is no help for it, no resisting it, no restraining it." ${ }^{56}$ Complex 
Marriage, then, can be seen as a means of diluting the effects of physical love by avoiding intense involvement with one person.

With Complex Marriage Noyes was trying to regulate the whole sexual system of the nineteenth century that clearly, to him and to many other reformers, had run riot. The nineteenth century reform impulse extended to sexual mores, even though it often created scandal merely to mention that problems existed. Noyes shared the personal sexual frustrations that often forced women into crusades for sexual reform. These movements enabled them to channel their frustrations over their traditional sex roles into respectable action. However, unlike such organizations as the Female Reform Society (which aimed to eliminate adultery and prostitution), he did not want merely to end existing sexual evils; he wanted to obviate them by starting from scratch with a brand new conception of sex and society. ${ }^{57}$

In addition to curing sexual evils, Noyes's doctrine corresponded with another central goal of his fellow crusaders: the promotion of self-control as the only effective means to reform. Beginning in the 1830 s, commentators began to increase traditional warnings against sexual excess. Control was seen as the foundation of a healthy personality, even in marriage. Excessive sexual relations were thought to weaken the couple both physically and morally. ${ }^{58}$ All the interest of the early nineteenth century in establishing rigid conventions regarding sexual behavior was probably related to the total disappearance of the "parental-run marriage system." Although this process had for over a century been on the wane, a general sense of laxity and absence of control now pervaded the system of at least middle-class courtship and relations between the sexes. Self-regulation, repression, and restricted boundaries of permitted sexual behavior were increasingly promoted in the nineteenth century. ${ }^{59}$ John Humphrey 
Noyes, therefore, shared the common concerns of his contemporaries; but his solution, while based on self-control, was too radical for widespread acceptance.

At this time, Noyes had determined that the establishment of Complex Marriage in an earthly setting could take place only in the distant future. Although he was aware of his idea's radical potential to remake society, he had no plans in 1837 to implement Complex Marriage. In fact, although he looked on American society as totally corrupt, he could offer no practical social solutions at all. Other than advocating Perfectionism, he offered no positive social approach to what he regarded as America's incurable social problems. In a letter to William Lloyd Garrison, Noyes tried to take advantage of Garrison's agreement with many of his views, to convince the abolitionist to subordinate that crusade to Perfectionism. Noyes described the various social evils destroying American society and characterized the United States government as "a bloated, swaggering libertine, trampling on the Bible-its own Constitution-its treaties with the Indians-the petitions of its citizens: with one hand whipping a negro tied to a liberty-pole, and with the other dashing an emaciated Indian to the ground." Noyes predicted the divinely ordained overthrow of the corrupt, hypocritical nation, but he could not say how this would happen. He had discovered from his "New York experience" that the fragmentation of moral reform movements rendered them too weak to cure the evils, so he could only urge Garrison and other true believers to "come out," so that they not partake in the nation's sin. Noyes tried to convince Garrison of the primacy of Perfectionism in the assault on sin:

All the abhorrence which now falls upon slavery, intemperance, lewdness, and every other specific vice, will in due time be gathered into one volume of victorious wrath against unbelief. I wait for that time as for the day of battle, regarding all the previous movements as only fencing-schools and maneuvers of military discipline-or at best as the preliminary skirmishes which precede a general engagement. I counsel you, and the people that 
are with you, if you love the post of honor-the forefront of the hottest battle of righteousness-to set your face toward perfect holiness. Your station is one that gives you power over the nations. Your city is on a high hill. If you plant the standard of perfect holiness where you stand, many will see and flow to it. I judge from my own experience that you will be deserted by many of your present friends; but you will be deserted as Jonah was by the whale-the world, in vomiting you up, will heave you upon the dry land. ${ }^{60}$

Garrison was quite in agreement with Noyes's letter, writing a month later to a fellow abolitionist that "total abstinence from sin, in this life, is not only commanded but necessarily obtainable." ${ }^{61}$ In many ways Noyes and Garrison were mutually sympathetic personalities. Both believed in immediatism in their respective fields; their language was apocalyptic, expressionistic, untempered, and entirely biblical; they were consummate publicists and indefatigable writers-it is impossible to imagine either man without a printing press at hand-in short, both men shared views that precluded compromise, half-measures, and moderation. Despite his sympathy, however, Garrison was too entrenched in his life's work to follow Noyes; indeed the concept of following anyone was as foreign to him as it was to Noyes.

Although Noyes did not succeed in converting Garrison, his contact with the abolitionist illustrated a turning point in his life. His letter to Garrison was prompted by a brimming self-confidence. He was moving easily and with self-assurance among important leaders of social reform. Noyes contacted other leading abolitionists, such as Gerrit Smith, offering to help them promote the abolitionist cause. ${ }^{62} \mathrm{He}$ had a pleasant and personally rewarding meeting with Charles G. Finney in New York in April, 1837. He had no trouble understanding Finney's position and no despair ensued when Finney refused to accept his version of Perfectionism. ${ }^{63}$ It is apparent, then, that by 1837 , John Humphrey Noyes had found his place in society and that he had finally 
come to grips with his identity. He was a leader, with followers; he had devised an important message for mankind concerning the establishment of the Kingdom of God on earth; and he possessed the most suitable means for broadcasting it. He had created for himself his own career, independent of the will of either parent. He had succeeded in converting most of his family to his beliefs. He was in control of himself, and even though things would not always go his way, and he would still suffer persecution and public opprobrium for his views, he never again plunged into lifethreatening depressions such as the one he had experienced in New York in $1834{ }^{64}$ His usual psychological cycle of "elevation, contradiction, despair, recovery, elevation, ${ }^{+65}$ while not entirely broken, decreased considerably in intensity. Noyes's new freedom, which he experienced through the ability to control both other people and himself, brought about a surge of creativity.

After 1837, his creative expressions shifted from religious to social interests, due to the necessity of implementing the doctrine of Complex Marriage. He had decided, in June, 1838 , to propose marriage to Harriet Holton. She had not ceased sending him money to run The Witness. In April, 1838, Noyes had become embarrassed by her generosity, and awkwardly tried to convey his thanks in a way that would not make him dependent on her, nor promise more than he was willing to give. "I beseech you for the Lord's sake," wrote Noyes, " either to stay your hand and stop running me in debt, or to make sure you look at my heart and not at my outward works for evidence that your generosity is not misplaced. Else you will tempt me to seek to please you."

During this time, Noyes was still attempting to contact Merwin, but she had left Ithaca, and he could not locate her. It is doubtful that, as G. W. Noyes stated, 
John Humphrey Noyes "quietly accepted the inevitable" fact that Merwin could never be his; he still tried to coax her to Oneida years later. ${ }^{67}$ Nevertheless, more practical considerations intervened which caused Noyes to consider taking Harriet Holton as his wife, although, as he explained in his letter proposing marriage, certainly not in the worldly sense:

Therefore we can enter into no engagements with each other which shall limit the range of our affections as they are limited in matrimonial engagements by the fashion of this world. I desire and expect my yokefellow will love all who love God, whether man or woman, with a warmth and strength of affection which is unknown to earthly lovers, and as freely as if she stood in no particular connection with me. . $^{68}$

Noyes continued to sketch the "matter-of-fact" considerations that motivated him to propose this "partnership." He wanted to be seen as a plain-speaking witness to the truth and not as a flatterer or as caught up on a "phrenzy" of romantic love. He told Holton he respected and loved her for her many desirable qualities, especially her "faith, kindness, simplicity, and modesty." He also wanted to free himself from the "reproach and evil surmisings" of immorality that his celibacy occasioned. Noyes tried to set Holton's mind at ease in regard to Abigail Merwin, abjuring any connection with her that would interfere with his current proposal. Finally, Noyes confessed that he was tired of being a vagabond in service to the Lord. "I see no reason why I should not have a 'certain dwelling-place,' and enter upon a course which is consistent with the duties of domestic life." ${ }^{.69}$

The next day Holton wrote back, accepting Noyes's offer gladly, with no reservations of any kind, desiring only Noyes's "society and instruction as long as the Lord pleases and when he pleases. ${ }^{170}$ On June 28, 1838, John Humphrey Noyes and Harriet Holton were married, a marriage which would outlast two communities based 
on Complex Marriage, enduring almost fifty years. She gave him the unstinting support, both financial and emotional, the loyalty, the devotion that he craved. He never had to fear for his self-esteem or identity where she was concerned. When he formally instituted Complex Marriage in 1846, she was his willing female counterpart; without her Noyes's great social experiment would never have gotten off the ground. Although frequently damned with faint praise by Noyes's biographers, she was a sturdy, reliable, totally convinced Perfectionist. It Noyes was the father of Oneida, she was truly the mother. 


\section{CHAPTER VI}

\section{CONCLUSION}

The Revivalists had for their great idea the regeneration of the soul. The great idea of the Socialists was the regeneration of society, which is the soul's environment. These ideas belong together, and are complements of each other. Neither can be successfully embodied by men whose minds are not wide enough to accept them both. . . .

On the one hand the Revivalists needed daily meetings and continuous criticism to save and perfect their converts; and these things they could not have without a thorough reconstruction of domestic life. . . [S]ociety was too strong for them, and their half-measures broke down, as all halfmeasures must. What they needed was to convert their churches into unitary families, and put them into unitary homes, where daily meetings and continuous criticism are possible;-and behold, this is Socialism! ${ }^{1}$

For John Humphrey Noyes, Socialism² began when he married Harriet Holton and was forced to practice what he had long preached. The couple settled in Putney, Vermont, and, along with several of Noyes's siblings, formed a Bible Society. Its first duty was seen as the publication of its doctrines. Accordingly, the small group taught itself the printing trade and issued The Witness. This paper was replaced by The Perfectionist in 1843, which in turn had its name changed to The Spintual Magazine, lasting until 1850 , after which the Oneida Community undertook the publication of hundreds of issues of newspapers, annual reports, handbooks, and explanatory books and pamphlets. God had his press.

However, Noyes did not immediately institute the practice of Complex Marriage among his followers, although by 1846 they were living as a community and held all their goods in common." But, "slowly and silently," Noyes moved toward his ideal society. ${ }^{-}$Perhaps the delay was caused by the absence of Abigail Merwin from 
the group, leading Noyes to feel that he was still missing his ideal mate. His biographer, G. W. Noyes, adheres to that point of view, even maintaining that Noyes tried to convince Merwin to join the Putney Bible Society. ${ }^{5}$ Whatever the case, Noyes soon found someone to take her place.

Among his most fervent converts to Perfectionism were George and Mary Cragin. Mary Cragin had had her health restored by Noyes, who had begun to practice faith healing. In the process she had fallen in love with him. Noyes was tempted to return her affection, but first reported the matter to the Community.

A searching talk ensued. Mr. Cragin at first was tempted to think that I was following the course of [free love], but he finally recognized the difference and gave judgment of approval. My wife promptly expressed her entire sanction. The last part of the interview was as amicable and happy as a wedding, and the consequence was that we gave each other full liberty. ${ }^{\sigma}$

Though the little community at first kept its practice of Complex Marriage a secret, it soon began to publicize it, believing that communism of persons was as biblically mandated as communism of goods. However, Putney proved to be infertile ground for such radical beliefs, and Noyes and his followers (numbering about fifty men, women, and children) were driven out in 1847 by offended clergymen and their congregations. A year later, through the agency of some New York Perfectionists, Noyes found an old farm for sale in Oneida and sent for his "extended" family saying. "The king-bee has lit, and the swarm is coming."7

The history of the Oneida Community is too well known to need retelling here. ${ }^{8}$ Suffice it to say that, for thirty years, over two hundred fifty people actually lived Noyes's vision of the ideal society. ${ }^{9}$ During that time, the religious character of Oneida was steadily eclipsed by the secular. The Community dropped the Putney's 
Bible study program, it held no regularly scheduled religious services, and the Oneida publications, which Noyes controlled, shifted from an emphasis on Perfectionist theology to "entertainment." The Witness gave way to The Circular, which was superceded in 1876 by the American Socialist, the titles alone signalling the most complete rout of religion. $^{10}$ Noyes, himself, became increasingly interested in the science of society and, in 1870 , published his History of American Socialisms. This is not to say that Noyes abandoned religion totally. Rather, social concerns increasingly absorbed him and the religious foundations of Oneida gradually atrophied.

John Humphrey Noyes fully enjoyed and exploited his role as Oneida's patriarch. he was directly responsible for every facet of its life, from its agricultural and industrial direction, to the communal raising of the Community's children, to the architecture of the Community's buildings. Through Oneida, he finally achieved what he had so long sought, security in a worthy career, and the unquestioning devotion of his extended family. The respect and deference with which he was treated by the members of the Community served to reinforce his painfully acquired identity. Noyes had had nothing but difficulty climbing the first five stages of the Eriksonian model of personality development. But now having the level foundation of a secure self-identity on which to build, Noyes accomplished the last three stages with little psychological turmoil.

Erikson's sixth stage of personality formation deals with the conflict between intimacy and isolation. ${ }^{11}$ Intimacy is the capacity to devole oneself to concrete commitments and partnerships. The opposite of this, isolation, involves distancing oneself from forces and people that appear threatening. Because Noyes controlled Oneida, because it was now his family, he was able to devote himself to it fully, 
without fear. From 1847 until the late 1870 s, Noyes rarely perceived threats to his hegemony. If he did, he dealt summarily with the problem member, in order to restore his sense of unchallenged leadership. ${ }^{12}$ Further, because of the practice of Complex Marriage, he was able to achieve intimacy, of varying degrees of intensity, with large numbers of his followers. Noyes had no reason to hide himself away in his room, as he had so often done in his college years. He was an acknowledged leader with many devoted followers; he blossomed in this leadership role, shaking off more and more religious restrictions and feeling free to pursue his social interests.

Noyes's later career at Oneida can be studied almost exclusively in the light of the seventh of Erikson's identity stages generativity versus stagnation. Generativity describes the concern for establishing and guiding the next generation. Where this fails to occur, the results can be a regression to an obsessive need for pseudo-intimacy, and a pervasive feeling of stagnation and personal emptiness. According to Erikson, "the mature man needs to be needed." Noyes considered himself, and was certainly considered by others, the "Father" of Oneida. Indeed, with his institution of a eugenics experiment at Oneida in 1869 , in which he figured prominently as the patriarch, this was literally true. Further, his ideas on childrearing and education formed the basis of these functions at Oneida.

The final stage of Erikson's paradigm involves the conflict between ego integrity and despair. This is actually the fruit of the previous seven stages. It is, Erikson explains, the acceptance of the "moral paternity" of oneself and of "one's one and only life cycle as something that had to be and that, by necessity, permitted of no substitutions." Death loses its sting in ego integration. The negative side of the 
acceptance of one's life is despair: the feeling that time is too short to create something new.

Erikson notes a particular application of this last stage to "homo religiosus." "This integrity crisis, last in the lives of ordinary men, is a life-long and chronic crisis" in the religious man. "He focuses in a precocious way on what it takes others a lifetime to gain a mere inkling of: the questions of how to escape corruption in living and how in death to give meaning to life." ${ }^{13}$ Noyes had already made this breakthrough when he announced that Christ's second coming had already occurred, that Perfectionism gave absolute assurance of salvation, and that anyone who was reborn in these beliefs was saved. Victory over death had already been achieved.

In addition, on a less theological level, Noyes spent much of his life fighting for a physical victory over death. He was deeply interested in all the health concerns of Oneida; he practiced faith healing with some success; his promotion of Male Continence can be seen as an effort to safeguard the health of the mother and preserve the vital forces of the father; his eugenics program granted him a measure of immortality through perfected offspring. But, in the last analysis, it was through his youthful theological beliefs in the Second Coming and in Perfectionism that he achieved this integrity of self in the face of death. By promising immediate salvation to himself and his followers, death-as the fruit of sin-was vanquished.

Noyes constructed his ideal society on these religious beliefs, but it did not take long before the society overwhelmed the theology, Oneida becoming an almost completely secular institution long before its breakup. But the secularizing tendencies did not spring from Oneida, itself, although the economic success of the Community, and its acceptance by the middle class citizens of upstate New York-Oneida was a 
major tourist attraction, and deliberately cultivated its image as such-certainly hurried the process. However, the social origins of Oneida had long since taken root in Noyes's mind. His upbringing in the dynamic Connecticut River Valley, where the flourishing market economy once gave his father his one chance for success, endowed Noyes with a deep "Yankee" streak that managed to surface even during his most trying religious or emotional moments. Market relations, capitalism, and money, were never far from Noyes's mind; he often used them as metaphors for his theological and philosophical speculations.

He finally felt free to indulge this tendency at the Oneida Community. His leadership and encouragement of industries such as the manufacture of steel animal traps, silver teaspoons, and sewing thread made Oneida unique among nineteenthcentury utopian communities, an economic success. Indeed, Oneida prospered so much that it could not man its own industries and was forced to hire outside workers for wages. Under the increasingly Yankee-inspired guidance of Noyes, Oneida willingly came to terms with the contemporary sector of industrialism. As Michael Fellman points out, with its eye on profits "the communist community ingested a capitalist factory." It In truth, Parker caught the essence of Noyes's character in the title of his biography, Yankee Saint.

Even more significant than economic concerns, however, was the lasting influence of Noyes's family on his life. As seen, Noyes considered the whole reason behind his social experiments to be the perfection and extension of the family unit. He disapproved of how his own family had been run; he believed that families should be more like those of the old Puritans, and less like his own. They should be patriarchies, where the fathers controlled every member. Thus, the Oneida Community 
could be understood to be a hugh patriarchal family-with Noyes at its head, ultimately controlling every aspect of its life, even to the sexual relations of its members. This was explicitly recognized by the Oneida Community in all its publications, and in Noyes's loving title, "Father."

He could not, however, shake off the effects of his love-hate relationship with his strong-willed mother. He came to believe that women needed to be controlled by patriarchs. Yet he never lost his impression of women as the dynamic workers who determined the health and prosperity of the family. Thus, at Oneida, women-while never liberated in the modern sense, and never considered as men's equals (they were, after all, part of the "descending fellowship")-were encouraged to find pleasure in sexual relations, to participate in all aspects of Oneida's business and economic life, to invent and use all possible labor-saving devices, and to wear both short hair and short skirts in the interest of efficiency. ${ }^{15}$

Probably most influential in the life and death of this social experiment were Noyes's youthful educational experiences. He had been the student of many great open-minded, even heretical men, and he learned his lessons well. While the Putney Community had depended chiefly on the Bible and Noyesian tracts as learning materials, at Oneida Noyes indulged his preference for a broad and open education for all his "children." The Community maintained a large library of almost 4,000 volumes, and subscribed to 140 periodicals. Included in the collection was Darwin's Origin of Species, which gave Noyes the idea for the eugenics experiment which he conducted at Oneida in the $1870 \mathrm{~s}^{16}$

Noyes insisted on the personal improvement of all Community members, particularly in intellectual matters. Oneida maintained an elementary school for all 
children, and a college-preparatory school for young men. Although Noyes dreamed of starting a college in the Community itself, open to outsiders as well as to members, this hope was never realized. However, the Community did send over a dozen young men to Yale. ${ }^{17}$

Yet, in the long run, educating its youth proved to be disastrous for Noyes's experimental society. At least one-third of the sixty-six young-adult Community members in 1881 had received some education outside of Oneida. Wide reading, appreciation of ideas and learning, and scientific training gave the youth both a broader educational background and a different cast of mind than their elders. In particular, this was the case with Theodore Noyes, his father's designated successor, a graduate of Yale medical school, and an open doubter of the theological tenets of Perfectionism. ${ }^{18}$ $\mathrm{He}$ and other outside-educated young men were the leaders in an internal insurrection to wrest control from the elder Noyes. That they succeeded in 1881 , and in the process moved Oneida from Perfectionist communism into full-fledged industrial capitalism, was a back-handed tribute to the open-minded educational philosophy of John Humphrey Noyes.

Of course, other influences on Oneida's breakup cannot be ignored, especially the increasingly negative outside reaction to Complex Marriage, and the continued secularization of the Community. But the new society that was unconsciously germinating in Noyes's mind all through his youth, and the particularly unbiblical shape it took, was a logical outcome of his upbringing, his education, his early theology, and-above all-his theory of Complex Marriage. As John Humphrey Noyes put it, with his typical optimism, "We made a raid into an unknown country, charted it, and returned without the loss of a single man, woman, or child." ${ }^{19}$ 


\section{NOTES}

\section{CHAPTER I}

\section{${ }^{1}$ Ralph Waldo Emerson, "The New England Reformers," in Ralph Waldo}

Emerson: Essays and Lectures, The Library of America (New York: Literary Classics of the United States, Inc., 1983), pp. 591-98.

${ }^{2}$ John Humphrey Noyes, Confessions of John H. Noyes. Part I. Confession of Religious Experience: Including a History of Modern Perfectionism (Oneida Reserve, NY: Leonard and Co., 1849), p. 1.

${ }^{3}$ John Humphrey Noyes, History of American Socialisms (Philadelphia: J. B. Lippincott \& Co., 1870; reprinted New York: Dover Publications, 1966), p. 23.

${ }^{4}$ Robert David Thomas, The Man Who Would be Perfect: John Humphrey Noyes and the Utopian Impulse (Philadelphia: University of Pennsylvania Press, 1977), p. xi.

${ }^{5}$ The history of source materials on John Humphrey Noyes is a troubled and vexed matter. Most of Noyes's manuscripts, letters, and journals were either destroyed of are unavailable to the public. Constance Noyes Robertson, John Humphrey Noyes's granddaughter, notes that George W. Noyes possessed "compendious archives" relating to his uncle, but that "sometime after [George's] death in $1941 \ldots$ the largest part of those invaluable and irreplaceable papers were destroyed." Constance Noyes Robertson, ed., Oneida Community: An Autobiography; 1851-1876 (Syracuse, NY: Syracuse University Press, 1970), p. 359.

Maren Carden traces the Oneida Communitys manuscript materials and personal documents to a Community historical committee which, around 1949, destroyed most of them by burning "half a room full" of paper." Maren Lockwood Carden, Oneida: Utopian Community to Modem Corporation (Baltimore: The Johns Hopkins Press, 1969), p. xviii.

One ray of hope regarding primary sources is held out by Robert S. Fogerty in his review of Thomas's psycho-biography. He notes that scholars have been denied access to manuscript materials in the Oneida collection, implying that such materials could someday be made available. Robert S. Fogerty. Review of The Man Who Would Be Perfect, by Robert David Thomas, in American Historical Review, LXXXIII (February, 1978), 276.

Finally, May Louise Sobel, in her 1968 dissertation. makes the important point that almost all of the information published by the Oneida Community about itself and its founder, is, in some respects, suspect as historical documentation. While Noyes and the Community believed firmly in spreading the world of God through the printed word, "secrecy or even seeming deception were religiously sanctioned" in order to make 
their point to the world. Most of what Oneida published, therefore, was what it wanted known about itself, and showed the Community as the Community wanted to be seen. May Louise Sobel, "An Experiment in Perfectionism: The Religious Life of the Putney and Oneida Communities" (unpublished Ph.D. dissertation, Boston University, 1968), pp. 1-3.

${ }^{6}$ George Wallingford Noyes, ed., Religious Experience of John Humphrey Noyes, Founder of the Oneida Community (New York: The Macmillan Company, 1923), p. v.

${ }^{7}$ Robert Allerton Parker, A Yankee Saint: John Humphrey Noyes and the Oneida Community (New York: G. P. Putnam's Sons, 1935), p. 310.

${ }^{8}$ Michael Fellman, The Unbounded Frame: Freedom and Community and Nineteenth Century American Utopianism, Contributions in American History, No. 26 (Westport, CT: Greenwood Press, Inc., 1973), p. 43.

\section{CHAPTER II}

${ }^{I}$ Noyes, History of American Socialisms, p. 351.

${ }^{2}$ Noyes, Confession, pp. 1-2.

${ }^{3}$ At the commencement exercises, John Noyes delivered "An oration in Chaldaic" on "The Importance of Piety to Sovereigns." Ralph Nading Hill, ed., The College on the Hill: A Dartmouth Chronicle (Hanover, NH: Dartmouth Publications, 1964), p. 133.

${ }^{4}$ George W. Noyes reports that when young John Humphrey Noyes was a student at Dartmouth, he met the famous Daniel Webster who assured him, "Young man, I wish I could do as much for you as your father did for me." G. W. Noyes, ed., Religious Experience, p. 2.

${ }^{5}$ These are the same words that John Noyes used to rebuke John Humphrey Noyes in 1837. "Mrs. Polly Noyes to [J. H.] Noyes," in Ibid., p. 366.

${ }^{6}$ Ibid., p. 6.

${ }^{7}$ Parker, Yankee Saint, p. 6.

8"Extract from College Journal [of John Humphrey Noyes]," in G. W. Noyes., ed., Religious Experience, p. 20.

${ }^{9}$ Ibid., p. 6.

${ }^{10}$ One of Polly Hayes's brothers was the father of Rutherford B. Hayes, president from 1877 to 1881 . 
${ }^{11}$ William Dean Howells, cited in Ibid., pp. 3-4.

${ }^{12}$ Parker, Yankee Saint, p. 4.

${ }^{13}$ G. W. Noyes, ed., Religious Experience, p. 7.

${ }^{14}$ Ibid., p. 4.

${ }^{15}$ Ibid., pp. 4-5.

${ }^{16}$ Randolph A. Roth, The Democratic Dilemma: Religion, Reform, and the Social Order in the Connecticut River Valley of Vermont, 1791-1850 (Cambridge: Cambridge University Press, 1987), pp. 22-23.

${ }^{17}$ Ibid., pp. 24-25.

${ }^{18}$ Ibid., p. 41.

${ }^{19}$ David Ludlum, Social Ferment in Vermont, 1791-1850 (New York: Columbia University Press, 1939), pp. 11-12; Roth, Democratic Dilemma, pp. 26-28.

${ }^{20}$ Ludlum, Social Ferment, p. 20.

${ }^{21}$ Ibid., pp. 31-33.

22Ibid., p. 13.

${ }^{23}$ Roth, Democratic Dilemma, p. 72.

${ }^{24}$ Ludlum, Social Ferment, p. 29.

${ }^{25}$ Roth, Democratic Dilemma, pp. 74-76.

${ }^{26}$ Ibid., p. 300 .

${ }^{27}$ Burned-over districts seem to be variously defined, based on the location of the author's subject matter. Roth, Democratic Dilemma, p. 1, describes this area as extending from the upper Connecticut River Valley of Vermont and New Hampshire to the Western Reserve of Ohio on the southern shore of Lake Erie. However, Whitney R. Cross, The Burned-over District: The Social and Intellectual History of Enthusiastic Religion in Western New York, 1800-1850 (New York: Harper \& Row, 1950), pp. 3-4. confines the "psychic highway" to that part of the state of New York that was west of the Adirondack and Catskill Mountains.

${ }^{28}$ Parker, Yankee Saint, p. 8, unaccountably gives September 11 th as John Humphrey Noyes's birthday. 
${ }^{29}$ Mary Jane Noyes married a Brattleboro attorney, Larkin G. Mead. In the $1830 \mathrm{~s}$, Brattleboro came to possess unique cultural advantages due to the presence of a water-cure which attracted many famous people, and Mary Noyes Mead's home became an intellectual and artistic gathering place. Her nine children became well schooled in the arts. Her son Larkin G. Mead, born in 1835, became a noted sculptor of the classical Italian school. William Rutherford Mead, born in 1846, became a prominent architect and a leading member of the firm McKim, Mead, and White. A daughter, Elinor Mead, married William Dean Howells. Dictionary of American Biography, XI, 472-73.

Elizabeth Noyes married and moved to Michigan where she died young. Joanna, who for a long time was John Humphrey Noyes's chief correspondent and confidant, went with her husband to Trinidad where she died of a tropical fever. G. W. Noyes, ed., Religious Experience, pp. 7, 326-27.

${ }^{30}$ Thomas, The Man Who Would Be Perfect, pp. 2-3.

${ }^{31}$ Quoted in Ibid., p. 3.

${ }^{32} \mathrm{G}$. W. Noyes, ed., Religious Experience, p. 8.

${ }^{33}$ Thomas, The Man Who Would Be Perfect, p. 3.

${ }^{34}$ John Demos, Past, Present, and Personal: The Family and the Life Course in American Histon (New York and Oxford: Oxford University Press, 1986), pp. 44-46, 57.

${ }^{35}$ Barbara Welter, "The Cult of True Womanhood: 1820-1860," in The American Family in Social-Historical Perspective, ed. by Michael Gordon (3rd ed.; New York: St. Martin's Press, 1983), pp. 384-86.

${ }^{36}$ Demos, Past, Present, and Personal, pp. 49-52.

${ }^{37}$ Parker, $A$ Yankee Saint, pp. 9-10. There is no record that Congressman John Noyes ever spoke on the floor of the House. He was appointed to one standing committee (Post Office and Post Roads) during the second session of his term, but he never spoke even on behalf of the one bill sponsored by that committee-which in any event had the overwhelming support of the House. Annals of Congress, 14th Cong.. 1st Sess. (1815-1816), 374 (Dec. 4, 1815); and 2nd Sess. (1815-1816), 232 (Dec. 2 1816), 1021 (Feb. 22, 1817).

${ }^{38}$ Demos, Past, Present, and Personal, p. 57.

${ }^{39}$ Unless otherwise noted, all of the following information and quoted material relating to the "Eight Ages of Man" can be found in Erik H. Erikson, Childhood and Society (2nd ed.; New York: W. W. Norton \& Company, Inc., 1963), pp. 247-74.

${ }^{40}$ The importance of Erikson's model to the historian is explained in John Demos, A Little Commonwealth: Family Life in Plymouth Colony (New York: Oxford 
University Press, Inc., 1970), pp. 128-30, and Erik H. Erikson, Young Man Luther: A Study in Psychoanalysis and History (New York: W. W. Norton \& Company, 1962), p. 256. There is a problem relating John Humphrey Noyes's life to these stages. As stated previously, there is little evidence about his childhood and none on his infancy. However, an historian can with justice extrapolate from a given culture to an individual in that culture, in order to advance a reasonable conjecture. This informed guess must contradict no known evidence, and must meet the dual criteria of honesty and common sense. Thus, an historian can make some informed guesses about the infancy and childhood of Noyes, based on what he knows about his cultural and social context.

${ }^{41}$ Parker, A Yankee Saint, p. 9.

${ }^{42}$ Many scholars now believe that Calvinist child rearing practices were aimed at the destruction of autonomy in children. As Philip G. Greven noted, "The autonomous will and self-assertiveness of the child must be reduced to impotency, be utterly suppressed and contained, or the child ultimately would be damned for eternity." Philip G. Greven, The Protestant Temperament: Patterns of Child-Rearing, Religious Experience, and the Self in Early America (New York: The New American Library, 1977), p. 35. A Calvinist parent is quoted by John Demos: "Be sure to maintain shame in them [young people]; for if that be once gone, there is no hope that they'll ever come to good." Demos, Little Commonwealth, p. 139. Although these two comments concerned seventeenth and eighteenth-century practices, they can also be applied with certainty to early nineteenth-century child rearing. Especially among pietistic, middle class parents such behavior persisted far into that century. William G. McLoughlin, "Evangelical Child Rearing in the Age of Jackson: Francis Wayland's Views on When and How to Subdue the Willfulness of Children," in Growing Up In America: Children In Historical Perspective, ed. by N. Ray Hiner and Joseph M. Daws (Urbana and Chicago: University of Chicago Press, 1985), pp. 94, 107.

${ }^{43}$ G. W. Noyes, ed., Religious Experience, p. 8.

${ }^{44}$ Mrs. Polly Noyes to Mrs. Crawford, Jan. 1937, quoted in Ibid., pp. 313-14. John Humphrey Noyes's rebukes to his mother continued at least until March 1839. One of his letters to her included the following exhortation:

So I grew up till I was too old to hearken to you. Then God took me in hand and gave me the same training [as you did] over again; and now he has sent me to reward you for your care over me by changing places with you and dealing with you as my little daughter. . . . You must expect I shall affectionately reprove you for thinking you know more than your father. My child, be still. You know but little and it becomes you to be modest. . . . Now I insist that you learn by experience and not continually fall into the same error. The things you "seem to see" are nothing but trash, broken bank bills that will never pass with me.

Noyes to his mother, Feb. 25, 1838, in G. W. Noyes, ed., John Humplrey Noyes: The Putney Community (Oneida, NY: By the author, 1931), pp. 27-28. 
${ }^{45} \mathrm{G}$. W. Noyes, ed., Religious Experience, pp. 37, 42, 150-51.

${ }^{46}$ Thomas, The Man Who Would Be Perfect, p. 3, and see below, Chapter Two.

${ }^{47}$ G. W. Noyes, ed., Religious Experience, p. 9.

${ }^{48}$ Ibid.

${ }^{49}$ Joseph F. Kett, Rites of Passage: Adolescence in America 1790 to the Present (New York: Basic Books, Inc., 1977), pp. 64-65.

${ }^{50}$ Ibid., pp. 9-11. According to G. W. Noyes this is the earliest of John Humphrey Noyes's writing to have been preserved.

${ }^{51}$ Ibid., p. 6; Parker, A Yankee Sainı, p. 9.

${ }^{52}$ G. W. Noyes, ed., Religious Experience, pp. 11-12.

${ }^{53}$ A school-fellow had called John Humphrey Noyes "a moving skeleton." G. W. Noyes, ed., Religious Experience, p. 13.

${ }^{54}$ Kett, Rites of Passage, p. 18 . Kett points out that most children left home for work rather than for education.

${ }^{55}$ G. W. Noyes, ed., Religious Experience, pp. 9, 13.

\section{CHAPTER III}

${ }^{1}$ (Oneida Association), Bible Communism: A Compilation of the Annual Reports and Other Publications of the Oneida Association and Its Branches (Brooklyn, NY: Office of The Circular, 1853; reprinted Philadelphia: Porcupine Press, 1972), p. 10.

2Parker, Yankee Saint, p. 12.

${ }^{3}$ G. W. Noyes, ed., Religious Experience, pp. 12-13.

${ }^{4}$ Kett, Rites of Passage, pp. 18-20.

5"Extract from College Journal, April 1, 1830," in G. W. Noyes, ed., Religious Experience, p. 23.

${ }^{6} I b i d .$, p. 12.

${ }^{7}$ Five children were born after John Humphrey Noyes, bringing the total number of Noyes children to nine. These five were the first George W., Horatio, born 
in 1815, Harriet Hayes (1817), Charlotte Augusta (1819), and William, later George W., (1822). Harriet, Charlotte, and George were all to be active in the Oneida Community. In his deep resentment of his mother, John Humphrey Noyes blamed her for his not being able to convince the four oldest to follow him:

What are the results of the complex education for which mother became responsible by her marriage? Taking as the tests the three oldest girls, who were never in my hands, and Horatio, who escaped from me, the facts are these: Mary married a Unitarian lawyer, Elizabeth an infidel physician, Joanna an irreligious West India merchant, and Horatio is the cashier of a bank, a Unitarian worldling. . . . The younger portion of the family is not to be brought into this account. I have saved them from the world by disregarding mother's advice and by teaching them to maintain their independence of her.

"Pride of Motherhood," paper by John Humphrey Noyes, late 1845, in G. W. Noyes, ed., The Putney Community, pp. 96-97.

${ }^{8}$ G. W. Noyes, ed., Religious Experience, p. 13. This pun is typical of Noyes's sense of humor.

${ }^{9}$ David F. Allmendinger, Jr., Paupers and Scholars: The Transformation of Student Life in Nineteenth-century New England (New York: St. Martin's Press, 1975). pp. 3, 5, n. 4.

$$
\begin{aligned}
& { }^{10} \text { Ibid., p. } 4 . \\
& { }^{11} \text { Ibid., p. } 11 . \\
& { }^{12} \text { Ibid., Tables } 10 \text { and } 11 \text {, pp. 131-33. } \\
& { }^{13} \text { Ibid., p. } 22 .
\end{aligned}
$$

${ }^{14} \mathrm{G}$. W. Noyes, ed., Religious Experience, p. 14. Squire Noyes also pointed out in his letter home that he was so happy revisiting his old college that he would have stayed regardless of his son's health.

${ }^{15}$ Ibid., p. 14.

${ }^{16}$ Hill, A Dartmouth Chronicle, p. 68. Dartmouth College v. Woodward, 4 Wheat. 518 (1819), followed at least four years of turmoil between the college's president and trustees over the dissolution of the college's charter and its removal to state control.

${ }^{17}$ Allmendinger, Paupers and Scholars, pp. 108-10.

${ }^{18}$ G. W. Noyes, ed., Religious Experience, p. 16. This letter could have arisen from Dean Shurtleff's delight "in saying pleasant things," (Hill, A Dartmouth Chronicle, 
p. 125), because it was unusual for New England colleges to correspond with the family of students; Dartmouth did not send regular reports to parents until after 1838 .

Allmendinger, Paupers and Scholars, p. 123.

18-30.

${ }^{19}$ "Extract from College Journal," in G. W. Noyes, ed., Religious Experience, pp.

${ }^{20}$ The growth of the concept of adolescence in the latter half of the nineteenth century was a response to the observation earlier in the century that youth seemed often in distress and were acting in ways that increasingly disturbed their elders. John Demos and Virginia Demos, "Adolescence in Historical Perspective," Journal of Mariage and the Family, XXXI (November, 1969), 638. 24-25.

21 "Extract from College Journal," in G. W. Noyes, ed., Religious Experience, pp.

${ }^{22}$ Ibid., pp. 20-23.

${ }^{23}$ Thomas, The Man Who Would Be Perfect, p. 11. G. W. Noyes, ed., Religious Experience, pp. 23-24, notes that this oration was in English, a sign that John Humphrey Noyes had fallen short of the highest honors that would call for an address in Greek or Latin.

${ }^{24}$ Thomas, The Man Who Would Be Perfect, p. 11.

${ }^{25}$ Erikson, Childhood and Society, pp. 261-62.

${ }^{26}$ Ibid., p. 262.

${ }^{27}$ G. W. Noyes, ed., Religious Experience, pp. 30-31. He never saw Caroline again.

${ }^{28}$ Ibid., p. 29.

${ }^{29} \mathrm{John}$ Humphrey Noyes, Confession, p. 2.

${ }^{30}$ G. W. Noyes, Religious Experience, p. 39.

${ }^{31}$ Ibid., pp. 36-38.

${ }^{32}$ J. Earl Thompson, Jr., "Abolitionism and Theological Education at Andover," The New England Quarterly, XLVII (June, 1974), 240.

${ }^{33}$ G. W. Noyes, Religious Experience, pp. $42-43$.

${ }^{31}$ Ibid., pp. 44-47. 
${ }^{35}$ Erikson, Childhood and Society, p. 257.

${ }^{36}$ Charles E. Rosenberg. The Cholera Years: The United States in 1832, 1849, and 1866 (Chicago: University of Chicago Press, 1962), p. 13.

${ }^{37}$ Ibid., p. 41.

${ }^{38} \mathrm{John}$ Humphrey Noyes, Confession, p. 4. At Oneida this method was perfected as "Mutual Criticism." [John Humphrey Noyes], Mutual Criticism (Oneida, NY: Office of The American Socialist, 1876; reprinted Syracuse, NY: Syracuse University Press, 1975), p. 71.

${ }^{39}$ Dictionary of Religious Biography, pp. 442-43.

${ }^{40}$ John Humphrey Noyes, Confession, pp. 4-5.

${ }^{41}$ Ibid., p. 5.

${ }^{42}$ Ibid., p. 6; emphases in the original.

${ }^{43}$ Lois W. Banner, "Religion and Reform in the Early Republic: The Role of Youth, American Quarterly, XXIII (December, 1971), 684-87; Thomas, The Man Who Would Be Perfect, p. 25.

${ }^{44}$ John Humphrey Noyes, Confession, p. 6.

45"Pride of Motherhood," in G. W. Noyes, ed., The Putney Community, p. 97.

${ }^{46}$ Banner, "Religion and Reform in the Early Republic," 684; Thompson, "Abolitionism and Theological Education at Andover," 254.

${ }^{47}$ Dictionary of Religious Biography, pp. 455-56.

${ }^{48}$ John Humphrey Noyes, Confession, p. 6.

${ }^{49}$ Thomas, The Man Who Would Be Perfect. p. 25.

${ }^{50}$ John Humphrey Noyes, Confession, pp. 10-11.

${ }^{51}$ Ibid., p. 10.

${ }^{52}$ Ibid., pp. 6-7.

${ }^{53}$ Rosenberg, The Cholera Years, pp. 56-60.

${ }^{54}$ Ibid., p. 39. 
${ }^{55}$ Ibid., p. 36. $60-61$.

56"Extract from College Journal," in G. W. Noyes, ed., Religious Experience, pp.

${ }^{57}$ John Humphrey Noyes, Confession, p. 10. On only one other occasion was he paid for preaching: he received seven dollars.

${ }^{58}$ Ibid., p. 19.

${ }^{59}$ G. W. Noyes, Religious Experience, pp. 48-50.

${ }^{60}$ Ibid., p. 53.

${ }^{61}$ John Humphrey Noyes, Confession, p. 19.

${ }^{62}$ G. W. Noyes, ed., Religious Experience, p. 124.

\section{CHAPTER IV}

${ }^{I}$ William James, The Varieties of Religious Experience (New York: The Modern Library, 1936), pp. 7-8.

${ }^{2}$ Horatio S. Noyes to Mary Noyes Mead, June 17, 1834, cited in G. W. Noyes, ed., Religious Experience, pp. 153-54. Horatio did try to comfort the family with the hope that John "probably will be able to satisfy your doubts as to his sanity" when he returned home.

${ }^{3}$ [Oneida Association], Bible Communism, p. 8.

${ }^{4}$ Fellman, The Unbounded Frame, p. 43.

${ }^{5}$ Erikson, Young Man Luther, p. 43.

${ }^{6} I b i d .$, p. 99.

${ }^{7}$ Ibid., pp. 100-101, 45.

${ }^{8}$ Ibid., p. 99.

${ }^{9}$ John Humphrey Noyes, Confession, p. 2.

${ }^{10}$ G. W. Noyes, ed., Religious Experience, p. 36.

${ }^{11} I$ bid., pp. 36-37. 
${ }^{12}$ Ibid., p. 37.

${ }^{13}$ Ibid., p. 39; Parker, Yankee Saint, p. 16, claims that this "experienced Christian" was Polly Noyes.

${ }^{14}$ Thomas, The Man Who Would Be Perfect, p. 14; Roth, The Democratic Dilemma, p. 187.

${ }^{15}$ Roth, Democratic Dilemma, pp. 189-90.

${ }^{16}$ Ibid., pp. 195-96.

${ }^{17}$ Ibid., pp. 193-94.

${ }^{18}$ Ibid., pp. 206-207. Roth (p. 207) posits a decline in the economy and a desire to overcome popular dislike of wealth and privilege as two plausible motives for the flight of the Connecticut River Valley's professional men into evangelical churches.

${ }^{19}$ Thomas, The Man Who Would Be Perfect, p. 14.

${ }^{20}$ Donald G. Mathews, "The Second Great Awakening as an Organizing Process, 1780-1830: An Hypothesis," American Quarterly, XXI (Spring. 1969), $27,33$. While Mathews explains the social-as opposed to religious-nature of the Second Great Awakening, his theory applies extremely well to Noyes's personal experience of the Awakening.

${ }^{21}$ Thomas, The Man Who Would Be Perfect, p. 17.

${ }^{22}$ Ibid.

${ }^{23}$ John Humphrey Noyes, Confession, pp. 2-3/

${ }^{24}$ Mother Ann Lee, the founder of the Shakers, also believed that the Second Coming had already occurred, with the difference that she was the reincarnation of Christ. Sidney A. Ahlstrom, A Religious History of the American People (New Haven and London: Yale University Press, 1972), p. 492; Ludlum, Social Ferment in Vermont, p. 245.

${ }^{25}$ John Humphrey Noyes, Confession, pp. 8-9.

${ }^{26} \mathrm{Ibid}$., p. 7.

${ }^{27}$ Ibid. Boyle's lifelong religious odyssey probably led him into more enthusiasms than any other prominent revivalist. He successively assumed and cast off his original Catholicism, Methodism, Presbyterianism, revivalism, Perfectionism, abolitionism. capitalism, socialism (he lived briefly at the Fourierist community at 
Northampton), Swedenborgianism, and faith healing. Cross, Burned-over District, pp. $189-90$.

\author{
${ }^{28} \mathrm{John}$ Humphrey Noyes, Confession, p. 12. \\ ${ }^{29}$ Cross, Bumed-over District, p. 242. \\ ${ }^{30}$ John Humphrey Noyes, Confession, p. 13. \\ ${ }^{31}$ Ibid., p. 10. \\ ${ }^{32}$ William G. McLoughlin, Revivals, Awakenings, and Reform: An Essay on
} Religion and Social Change in America, 1607-1977 (Chicago: University of Chicago Press, 1978), pp. 94-96.

${ }^{33}$ [Oneida Association], Bible Communism, p. 7.

${ }^{34}$ Norman Walter Haight, "Faith and Freedom in Christian Utopia: An Analysis of the Thought of John Humphrey Noyes and the Oneida Community" (unpublished Ph.D. dissertation, Syracuse University, 1972), p. 47.

${ }^{35}$ Quoted in Cross, Burned-over District, p. 250. emphasis.

${ }^{36}$ Quoted in Haight, "Faith and Freedom in Christian Utopia," p. 48; my

${ }^{37}$ John Humphrey Noyes, Confession, p. 11. It was worthy of remark that when G. W. Noyes compiled and edited his uncle's works, this line was eliminated. See G. W. Noyes, ed., Religious Experience, pp. 66-67.

${ }^{38}$ John Humphrey Noyes, Confession, p. 13.

${ }^{39}$ Erikson, Young Man Luther, pp. 102-103.

${ }^{40}$ John Humphrey Noyes, Confession, p. 16.

${ }^{41}$ Ibid., p. 17.

${ }^{42}$ Ibid., p. 18.

${ }^{43}$ Ibid., pp. 18-19, 23.

${ }^{44}$ Ibid., p. 22.

${ }^{45}$ Ibid., pp. 20-21. 
${ }^{46}$ Polly Noyes, when her son wrote to her of his second conversion, is reported to have exclaimed, "What does John mean?" G. W. Noyes, ed., Religious Experience, p. 111.

${ }^{47}$ John Humphrey Noyes, Confession, p. 42.

${ }^{48}$ John Humphrey Noyes to Abigail Merwin, December 28,1835 , in G. W. Noyes, ed., Religious Experience, p. 352.

${ }^{49}$ John Humphrey Noyes, Confession, p. 30.

${ }^{50}$ Cross, Burned-over District, pp. 242-43.

${ }^{51}$ Erikson, Young Man Luther, p. 44.

${ }^{52}$ Thomas, The Man Who Would Be Perfect, pp. 54-56.

${ }^{53}$ John Humphrey Noyes, Confession, p. 42.

${ }^{54}$ Ibid., p. 37.

${ }^{55}$ Ibid., p. 38.

${ }^{56}$ Ibid., p. 42, Noyes's emphasis.

${ }^{57}$ For a description of the transition required of nonindustrial people, see Herbert G. Gutman, "Work, Culture, and Society in Industrializing America, 1815-1919," American Historical Review, LXXVIII (June, 1973), 531-89.

${ }^{58}$ John Humphrey Noyes, Confession, pp. 42-43.

${ }^{59}$ Ibid., p. 38; Thomas, The Man Who Would Be Perfect, p. 61.

${ }^{60}$ John Humphrey Noyes, Confession, pp. 44-45. Thomas, The Man Who Would Be Perfect, p. 57, notes that Noyes was so close to psychic dissolution that he resorted to heavy eating and drinking in order to feel full and alive.

${ }^{61}$ John Humphrey Noyes, Confession, p. 44, Noyes's emphasis.

${ }^{62}$ Ibid., p. 40.

${ }^{63}$ Ibid., p. 46.

${ }^{64}$ Ibid., p. 45.

${ }^{65}$ Ibid., p. 41. 
${ }^{66}$ David Harrison to Harriet A. Holton (soon to be Mrs. John Humphrey Noyes), April 18, 1838, in G. W. Noyes, ed., The Putney Community, p. 29.

${ }^{67}$ Noyes to his mother, September 9,1835 , in G. W. Noyes, ed., Religious Experience, pp. 232-40.

\section{CHAPTER V}

${ }^{1}$ John Humphrey Noyes, History of American Socialisms, p. 24.

2John Humphrey Noyes, Confession, p. 41.

${ }^{3}$ Ibid., p. 47.

${ }^{4}$ Noyes to Horatio Noyes, July 2, 1834, cited in Thomas The Man Who Would Be Perfect, p. 68.

${ }^{5}$ John Humphrey Noyes, Confession, p. 19.

${ }^{6}$ Ibid.

${ }^{7}$ Noyes to his father, October 8,1834 , in G. W. Noyes, ed., Religious Experience, p. 171.

${ }^{8}$ Noyes to his mother, November 2, 1834, in Ibid., p. 172.

${ }^{9}$ Noyes to Elizabeth Noyes, November 12, 1834, in Ibid.. p. 175.

${ }^{10}$ Noyes to Joanna Noyes in Ibid., p. 321.

${ }^{11}$ Ibid., p. 320.

${ }^{12}$ G. W. Noyes, ed., The Putney Community, p. 30.

${ }^{13}$ Noyes to his mother, December 2, 1834, in G. W. Noyes, ed., Religious Experience, pp. 176-77.

${ }^{14}$ Noyes to his mother, September 9, 1835, in Ibid., pp. 235-37.

${ }^{15}$ Harriet A. Holton was born in Springfield, Vermont, November 28, 1808, into a family at least as distinguished as Noyes's. Her maternal grandfather was Mark Richards who had been a lieutenant governor of Vermont and a member of Congress. Left an orphan at an early age, she was raised by this grandfather. Richards seems to have been a remarkably liberal guardian in nineteenth-century New England terms: he educated Holton well; he countermanded efforts to reconvert her when she became a 
Perfectionist, saying that she had a right to her own beliefs; even Holton's marriage to the "crazy" John Noyes did not faze him. Richards declared that he did not want to control his granddaughter, and that she should suit herself. He provided for her generously in his will, a provision which ultimately benefitted Noyes's Oneida Community with at least $\$ 16,000$. Holton had flirted with Unitarianism, later joined the Congregational Church, but when she heard Noyes preach in 1834, she converted to Noyesian Perfectionism and remained fully committed to that belief all her life.

These details of Holton's life are drawn from G. W. Noyes, ed., The Putney Community, pp. 15-17. Her financial contribution to Oneida is given in Carden, Oneida, pp. 18-19.

${ }^{16}$ Harriet A. Holton to John Humphrey Noyes, June 12, 1838, in G. W. Noyes, ed., The Putney Community, p. 20.

${ }^{17}$ John Humphrey Noyes, Confession, p. 41.

${ }^{18}$ Chauncey Dutton to John Humphrey Noyes, July 18,1834 , in G. W. Noyes, ed., Religious Experience, pp. 156-57. Dutton does not specify what caused Abigail Merwin to cast off Perfectionism, but he does relate the case of Brother Lowrie (p. 157) who had

struck his colors and gone back to the Free Church. This is a hard blow truly. He got into a Jackson celebration on the Fourth of July, and celebrated the day in Jackson style, thinking he was doing God service.

Now he has come to the conclusion that he sinned, and he abandons the eternal promise. ... I I have not learned that he did anything outrageous. $\mathrm{He}$ arose early, fired cannon, drank wine, took dinner, and went sailing. I do not think he sinned, but believe the devil made a fool of him.

${ }^{19}$ John Humphrey Noyes, Confession, pp. 48-49.

${ }^{20}$ G. W. Noyes, ed., Religious Experience, pp. 354-55. G. W. Noyes interjected that John Humphrey Noyes "knew [Merwin's] window; and his feelings of bereavement and yearning, especially when he passed her lighted room at night, were unutterable."

${ }^{21}$ Ibid., p. 355 .

${ }^{22}$ Ibid.

${ }^{23}$ Ibid., pp. 356-57. Noyes made these remarks in an informal homily, or "Home-Talk"-the Oneida Community's only form of religious observance-at Oneida in April, 1851.

${ }^{24}$ John Humphrey Noyes to Abigail Merwin, December 28, 1835, in Ibid., pp.

${ }^{25} \mathrm{G}$. W. Noyes, ed., The Putney Community, p. 3. 
26"Home Talk" by John Humphrey Noyes, printed in the Circular, August 16, 1875, quoted in Robertson, Oneida Community: An Autobiography, pp. 126-27.

${ }^{27}$ Carden, Oneida, pp. 49-61.

${ }^{28}$ [Oneida Association], Bible Communism, pp. 42-44.

${ }^{29}$ Ibid., p. 50.

${ }^{30}$ Circular, V (February 28, 1856), quoted in Thomas, The Man Who Would Be Perfect, p. 103.

${ }^{31}$ Ellen K. Rothman, "Sex and Self-Control: Middle-Class Courtship in America, 1770-1870," in Michael Gordon, ed., The American Family in Social-Historical Perspective (New York: St. Martin's Press, 1983), p. 406.

32Quoted in Thomas, The Man Who Would Be Perfect, p. 103.

${ }^{33}$ [Oneida Association], Bible Communism, pp. 37, 53.

${ }^{34}$ Gates started his paper to publicize his own theory of ideal sexual relations: husbands and wives should live together only as long as it was their "free and mutual choice to do so." When strife and disagreement set in, they must be free to change partners. G. W. Noyes, ed., The Putney Community, p. 4.

${ }^{35}$ John Humphrey Noyes, Confession, p. 53.

${ }^{36}$ Thomas, The Man Who Would Be Perfect, p. 70.

${ }^{37}$ Allan R. Pred, Urban Growth and the Circulation of Information: The United States System of Cities, 1790-1840, Harvard Studies in Urban History (Cambridge. MA: Harvard University Press, 1973), Table 2.1, p. 21.

${ }^{38}$ Frank Luther Mott, American Joumalism A History: 1690-1960 (New York: The Macmillan Company, 1962), p. 206.

${ }^{39}$ Richmond Times and Compiler, quoted in Ibid., p. 216.

${ }^{40}$ Ibid., p. 304.

${ }^{41}$ G. W. Noyes, ed., Religious Experience, p. 361.

${ }^{42}$ Mott, American Journalism, p. 304.

${ }^{43}$ Parker, Yankee Saint, p. 192.

${ }^{44}$ John Humphrey Noyes, Confession, p. 54. 
${ }^{45}$ Ibid., p. 55.

${ }^{46}$ Ironically, Lovett had been sent on behalf of the New York Perfectionists to convert Noyes, "to set him right." Such was the force of Noyes's personality that he converted Lovett to New Haven Perfectionism, instead. Ibid.

${ }^{47}$ G. W. Noyes, ed., Religious Experience, pp. 198-99.

${ }^{48}$ Ibid., pp. 197-98.

${ }^{49}$ These types of accusations caused the break-up of both of Noyes's communities. His first society at Putney was attacked by Vermonters outraged over the practice of Complex Marriage. A formal charge filed in the Windham County Court, December 12,1848, charged Noyes with adultery and fornication. He escaped prosecution by forfeiting his bond and fleeing to New York. The Vermont forces were led by the Rev. Hubbard Eastman, who later wrote a book of over 430 pages to immortalize his charges against John Humphrey Noyes. Hubbard Eastman, Noyesism Unveiled: A History of the Sect Self-Styled Perfectionists; with a Summary View of Their Leading Doctrines (Brattleboro, VT: By the Author, 1849).

At Oneida, sex-related charges were mingled with internal problems in ending the communistic phase of the community. Again, local clergymen led a concerted attack against the community's practice of Complex Marriage. This time (1887) they threatened to charge all male community members (including Noyes) with statutory rape and adultery. Carden, Oneida, pp. 100-102.

${ }^{50}$ Cross, Burned-Over District, pp. 248-49.

${ }^{51}$ John Humphrey Noyes to his mother, January 21,1841 , in G. W. Noyes, ed., Religious Experience, p. 356. Noyes wrote in his first issue that he "had long desired to traverse the central and western parts of New York, because [he] regarded them as the birth-place of many of the mightiest moral and political movements of the times in which we live." Extracts from The Witness, quoted in Ibid., p. 339.

${ }^{52}$ Quoted in G. W. Noyes, ed., The Putney Community, pp. 6-7. Noyes, looking back at the effects of the "Battle-Axe letter" on his career, wrote, "From the time of the publication of that letter I felt that I was called, even under the heaviest penalties, to defend and ultimately carry out the doctrine of communism in love. . . I I am not sure that I should ever have broached our sexual theory of my own free motion." Quoted in Ibid., p. 10.

${ }^{53}$ Ibid., pp. 7-8.

${ }^{54}$ Parker, Yankee Saint, p. 44.

${ }^{55}$ Thomas, The Man Who Would Be Perfect, pp. 88-89.

${ }^{56}$ Circular IX (April 27, 1874), quoted in Ibid., p. 89. 
${ }^{57}$ Carroll Smith Rosenberg. "Beauty, the Best and the Militant Woman: A Case Study in Sex Roles and Social Stress in Jacksonian America," American Quarterly XXIII (October, 1971), 564-65.

${ }^{58}$ Charles E. Rosenberg, "Sexuality, Class and Role in 19th-Century America," American Quarterly XXV (May, 1973), 135-38.

${ }^{59}$ Rothman, "Sex and Self-control," 393-407.

${ }^{60}$ Wendell Phillips Garrison and Francis Jackson Garrison, William Lloyd Gamison, 1805-1879: The Story of his Life Told by his Children 4 Vols. (New York: The Century Co., 1885), II: 145-48.

${ }^{61}$ Garrison to Henry C. Wright, April 16, 1837, in Ibid., p. 149.

${ }^{62}$ G. W. Noyes, ed., Religious Experience, pp. 330-31.

${ }^{63}$ Ibid., pp. 333-35. In response to a note from Noyes praising one of his lectures. Finney wrote to Noyes requesting an interview. Noyes was extremely gratified that he was being taken seriously by the elder statesman of Perfectionism. He later said of that meeting:

Immediately upon receipt of this letter, I went to New York and had an interview of several hours with Mr. Finney. He received my conversation in the spirit which his letter manifests, and I rejoice that I have an opportunity of publicly testifying that the candor and kindness of his behavior toward me was surpassingly beautiful and refreshing. In the course of our conversation he bore witness repeatedly and with warmth that he perceived in me no indications of insanity, and I left him with a reanimated hope of gaining for myself and for the gospel which I preach that public confidence without which testimony is powerless. Ibid., p. 335.

${ }^{64}$ Since his days in college. Noyes had believed that a Christian was identified by suffering and oppression. He caused a great furor at Yale over the question of whether persecution is the test of faith. Although the esteemed Dr. Taylor decided in the negative (citing the experience of the best ministers in Connecticut), Noyes maintained that he never expected or desired "to be treated better than Jesus Christ and his gospel are treated." John Humphrey Noyes, Confession, p. 11.

According to R. Laurence Moore, this concept of being persecuted-of "outsiderhood"-is a typically American method of expressing religious conviction. Small religious groups, seemingly oppressed by the mainstream religions for speaking the "language of dissent," represent the quintessential American religious experience. R. Laurence Moore, Religious Outsiders and the Making of Americans (New York and Oxford: Oxford University Press, 1986), pp. vii-xv.

${ }^{65}$ Thomas, The Man Who Would Be Perfect, p. 83. 
${ }^{66}$ John Humphrey Noyes to Harriet A. Holton, April 3, 1838, in G. W. Noyes, ed., The Putney Community, p. 13.

${ }^{67}$ G. W. Noyes, ed., The Putney Community, p. 14.

${ }^{68}$ Ibid., p. 194.

${ }^{69} \mathrm{John}$ Humphrey Noyes to Harriet A. Holton, June 11, 1838, in Ibid., p. 17.

${ }^{70}$ Ibid., pp. 18-19. At this time Noyes wrote a "Farewell Lay to Abigail" which showed that he had not in the last given her up. Ibid., pp. 14-15. It began,

I will not give you back your heart,

I've wooed and fairly won it,

And sooner with my life I'll part,

You may depend upon it.

22.

${ }^{71}$ Harriet A. Holton to John Humphrey Noyes, June 12, 1838, in Ibid., pp. 20-

\section{CONCLUSION}

${ }^{1}$ John Humphrey Noyes, History of American Socialisms, p. 26.

${ }^{2}$ Although Noyes did not define this term in his History of American Socialisms, it is clear that he was referring to communal experiments in perfecting society, and not to the political doctrine of state ownership of the means of production. Nevertheless, in most experimental societies, communism of goods, based on the Bible, was practiced.

${ }^{3}$ G. W. Noyes, ed., The Putney Community, p. 192.

${ }^{4}$ Quoted in Ibid., pp. 192-93.

${ }^{5}$ Ibid., p. 194.

6"My First Act in Sexual Freedom by J. H. Noyes," in Ibid., pp. 201-202. p. 389.

${ }^{7}$ Letter of John Humphrey Noyes to George Cragin, February 4, 1848, in Ibid.,

${ }^{8}$ Many members of the Oneida Community wrote reminiscences after its breakup. These include Allen Estlake [Abel Easton], The Oneida Community: $A$ Record of an Attempt to Cary Out the Principles of Christian Unselfishness and Scientific Race-Improvement (London: George Redway, 1900); Pierrepont Noyes [son of John 
Humphrey Noyes], My Father's House; an Oneida Boyhood (New York: G. P. Putnam's Sons, 1935); Harriet M. Worden, Old Mansion House Memories (Oneida, NY: By the author, 1950), and Corinna Ackley Noyes [Mrs. Pierrepont Noyes], The Days of My Youth (Kenwood, NY: By the author, 1960).

Secondary works on Oneida are legion. In addition to the works by Carden Hayden, Parker, and Constance Noyes Robertson cited herein, see especially Charles Nordhoff, The Communistic Societies of the United States (New York: Hillary House Publishers, Ltd., 1960 [originally published 1875]); Lawrence Foster, Religion and Sexuality: Three American Communal Experiments of the Nineteenth Century (New York and Oxford: Oxford University Press, 1981); and Rosabeth Moss Kanter, Commitment and Community: Communes and Utopias in Sociological Perspective (Cambridge: Harvard University Press, 1972).

${ }^{9}$ Oneida was formally dissolved as a communistic society in 1881 , but continues as a joint-stock company (manufacturing silverware) to the present.

${ }^{10}$ Carden, Oneida, p. 91.

${ }^{11}$ Erikson, Childhood and Society, pp. 247-74.

${ }^{12}$ One of the rare instances of rebellion against Noyes's authority occurred in 1867, when his son Victor refused to submit to his word as to the law. Noyes thereupon had him committed to an insane asylum, and warned him that he would remain there until he surrendered. Noyes wrote, "You will have to be modest enough to acknowledge that you have been insane (which you have hardly done yet) and wipe out all notions you have adopted during your insanity, and begin again as a little child." Noyes's words contain unmistakable echoes of his struggle for authority with his mother. Leadership of Oneida had not solved all his personality difficulties. Quoted in Fellman, The Unbounded Frame, p. 47.

${ }^{13}$ Erikson, Young Man Luther, p. 261.

${ }^{14}$ Fellman, The Unbounded Frame, p. 58.

${ }^{15}$ Some of the Community inventions specifically designed to save female labor were a lazy-susan dining table, a mop-wringer, an improved washing machine, and an institutional potato peeler. Women also invented a new style of short dress worn with bloomer-like "pantalettes" and a so-called "Final Shoe" to replace the traditional highheeled, high-laced boot. Dolores Hayden, Seven American Utopias: The Architecture of Communitarian Socialism, 1790-1975 (Cambridge, MA and London: The MIT Press, 1976), p. 198.

Furthermore, John Humphrey Noyes had strong feelings about women's dress. He felt that "[Women] are not only shut up, but fettered. Gowns operate as shackles, and they are put on that sex which as most talent in the legs. . . Women's dress is a standing lie. It proclaims that she is not a two-legged animal, but something like a churn, standing on castors! Such are the absurdities into which the false principle of 
shame and sexual isolation betray the world." [Oneida Association], Bible Communism, pp. 61-62.

${ }^{16}$ Since the word "eugenics" had not yet been coined, Noyes invented the term "stirpiculture," from the Latin stirps, meaning stock, stem, or root to describe this experiment. Carden, Oneida, p. 61.

${ }^{17}$ Ibid., pp. 67-69.

${ }^{18}$ Ibid., p. 96.

${ }^{19}$ Quoted in Hayden, Seven American Utopias, p. 190. 


\section{SELECTED BIBLIOGRAPHY}

Achorn, Eric. "Mary Cragin, Perfectionist Saint." The New England Quarterly, XXVIII (December, 1955), 490-518.

Ahlstrom, Sydney A. A Religious History of the American People. New Haven and London: Yale University Press, 1972.

Allmendinger, David F., Jr. Paupers and Scholars: The Transformation of Student Life in Nineteenth-Century New England. New York: St. Martin's Press, 1975.

Banner, Lois W. "Religion and Reform in the Early Republic: The Role of Youth." American Quarterly, XXIII (December, 1971), 677-95.

Carden, Maren Lockwood. Oneida: Utopian Community to Modern Corporation. Baltimore: The Johns Hopkins Press, 1969.

Cross, Whitney R. The Burned-over District: The Social and Intellectual History of Enthusiastic Religion in Western New York, 1800-1850. New York: Harper \& Row, 1950.

Demos, John, and Demos, Virginia. "Adolescence in Historical Perspective." Journal of Marriage and the Family, XXXI (November, 1969), 632-43.

Demos, John. A Little Commonwealth: Family Life in Plymouth Colony. New York: Oxford University Press, Inc., 1970.

- Past, Present and Personal: The Family and the Life Course in American History. New York and Oxford: Oxford University Press, 1986.

Eastman, Hubbard. Noyesism Unveiled: A History of the Sect of Self-Styled Perfectionists With a Summary View of Their Leading Doctrines. Brattleboro, VT: By the Author, 1849.

Emerson, Ralph Waldo. "New England Reformers." Ralph Waldo Emerson: Essays and Lectures. The Library of America. New York: Literary Classics of the United States, Inc., 1983.

Erikson, Erik H. Childhood and Society. 2nd ed. New York: W. W. Norton \& Company, Inc., 1963.

- Young Man Luther: A Study in Psychoanalysis and History. New York: W. W. Norton \& Company, 1962. 
Estlake, Allan [Abel Easton]. The Oneida Community: A Record of an Attempt to Carry Out the Principles of Christian Unselfishness and Scientific RaceImprovement. London: George Redway, 1900.

Fellman, Michael. The Unbounded Frame: Freedom and Community in Nineteenth Century American Utopianism. Contributions in American History, No. 26. Westport, CT and London: Greenwood Press, Inc., 1973.

Fogerty, Robert S. Review of The Man Who Would Be Perfect, by Robert David Thomas, in American Historical Review, LXXXIII (February, 1978), 276.

Foster, Lawrence. Religion and Sexuality: Three American Communal Experiments of the Nineteenth Century. New York and Oxford: Oxford University Press, 1981.

Garrison, Wendell Phillips, and Garrison, Francis Jackson. William Lloyd Garrison, 1805-1879: The Story of his Life Told by his Children. Vol. II. New York: The Century Co., 1885.

Greven, Philip G. The Protestant Temperament: Patterns of Child-Rearing, Religious Experience, and the Self in Early America. New York: The New American Library, 1977.

Gutman, Herbert G. "Work, Culture, and Society in Industrializing America." American Historical Review, LXXVII (June, 1973), 531-89.

Haight, Norman Walter. "Faith and Freedom in Christian Utopia: An Analysis of the Thought of John Humphrey Noyes." Ph.D. dissertation, Syracuse University, 1972.

Hayden, Delores. Seven American Utopias: The Architecture of Communitarian Socialism, 1790-1975. Cambridge, MA and London: The MIT Press, 1976.

Hill, Ralph Nading, ed. The College on the Hill: A Dartmouth Chronicle. Hanover, NH: Dartmouth Publications, 1964.

Hinds, William Alfred. American Communities. Oneida, NY: Office of The American Socialist, 1878; reprinted with an introduction by Henry Bamford Parkes, Gloucester, MA: Peter Smith, 1971.

James, William. The Varieties of Religious Experience. New York: The Modern Library, 1936.

Kanter, Rosabeth Moss. Commitment and Community: Communes and Utopias in Sociological Perspective. Cambridge, MA: Harvard University Press, 1972.

Kett, Joseph F. "Adolescence and Youth in Nineteenth-Century America." Joumal of Interdisciplinary History, II (Autumn, 1971), 283-98. 
- Rites of Passage: Adolescence in America 1790 to the Present. New York: Basic Books, Inc., 1977.

Ludlum, David. Social Ferment in Vermont, 1791-1850. New York: Columbia University Press, 1939.

Mathews, Donald G. "The Second Great Awakening as an Organizing Process, 17801830: An Hypothesis." American Quarterly, XXI (Spring, 1969), 23-43.

McLoughlin, William G. "Evangelical Child Rearing in the Age of Jackson: Francis Wayland's Views on When and How to Subdue the Willfulness of Children." Growing Up in America: Children in Historical Perspective. Edited by N. Ray Hiner and Joseph M. Dawes. Urbana and Chicago: University of Chicago Press, 1985.

- Revivals, Awakenings, and Reform: An Essay on Religion and Social Change in America, 1607-1977. Chicago: University of Chicago Press, 1978.

Moore, R. Laurence. Religious Outsiders and the Making of Americans. New York and Oxford: Oxford University Press, 1986.

Mott, Frank Luther. American Journalism A History: 1690-1960. New York: The Macmillan Company, 1962.

Nordhoff, Charles. The Communistic Societies of the United States. New York: Hillary House Publishers, Ltd., 1960 (originally published 1875).

Noyes, Corinna Ackley. The Days of My Youth. Kenwood, NY: By the Author, 1960.

Noyes, George Wallingford, ed. John Humphrey Noyes: The Putney Community. Oneida, NY: By the Author, 1931.

- Religious Experience of John Humphrey Noyes, Founder of the Oneida Community. New York: The Macmillan Company, 1923.

Noyes, John Humphrey. Confessions of John H. Noyes. Park I: Confession of Religious Experience: Including a History of Modern Perfectionism. Oneida Reserve, NY: Leonard and Co., 1849.

- History of American Socialisms. Philadelphia: J. B. Lippincott \& Co., 1870.

- Mutual Criticism. Oneida, NY: Office of The American Socialist, 1876; reprinted Syracuse, NY: Syracuse University Press, 1975.

Noyes, Pierrepont. My Father's House; an Oneida Boyhood. New York: Farrer \& Rinehart, 1937. 
[Oneida Association]. Bible Communism: A Compilation of the Annual Reports and Other Publications of the Oneida Association and its Branches. Brooklyn, NY: Office of The Circular, 1853; reprinted Philadelphia: Porcupine Press, 1972.

Parker, Robert Allerton. A Yankee Saint: John Humphrey Noyes and the Oneida Community. New York: G. P. Putnam's Sons, 1935.

Pred, Allan R. Urban Growth and the Circulation of Information: The United States System of Cities, 1790-1840. Harvard Studies in Urban History. Cambridge, MA: Harvard University Press, 1973.

Robertson, Constance Noyes. Oneida Community: An Autobiography, 1851-1876. Syracuse, NY: Syracuse University Press, 1970.

- Oneida Community: The Breakup, 1876-1881. Syracuse, NY: Syracuse University Press, 1972.

Rosenberg, Carroll Smith. "Beauty, the Beast and the Militant Woman: A Case Study in Sex Roles and Social Stress in Jacksonian America." American Quarterly, XXIII (October, 1971, 562-84.

Rosenberg, Charles E. "Sexuality, Class and Role in 19th Century America." American Quarterly, XXV (May, 1973), 131-53.

- The Cholera Years: The United States in 1832, 1849 and 1866. Chicago: University of Chicago Press, 1962.

Roth, Randolph A. The Democratic Dilemma: Religion, Reform, and the Social Order in the Connecticut River Valley of Vermont, 1791-1850. Cambridge: Cambridge University Press, 1987.

Rothman, Ellen K. "Sex and Self-Control: Middle-Class Courtship in America, 17701870." The American Family in Social-Historical Perspective. Edited by Michael Gordon. 3rd ed. New York: St. Martin's Press, 1983.

Sobel, May Louise. "An Experiment in Perfectionism: The Religious Life of the Putney and Oneida Communities." Ph.D. dissertation, Boston University, 1968.

Thomas, John L. "Romantic Reform in America, 1815-1865." American Quarterly, XVII (Winter, 1965), 656-81.

Thomas, Robert David. The Man Who Would Be Perfect: John Humphrey Noyes and the Utopian Impulse. Philadelphia: University of Pennsylvania Press, 1977.

Thomas, J. Earl. "Abolitionism and Theological Education at Andover." New England Quarterly, XLVII (1974), 238-61. 
Welter, Barbara. "The Cult of True Womanhood: 1820-1860." The American Family in Social-Historical Perspective. Edited by Michael Gordon. 3rd ed. New York: St. Martin's Press, 1983.

Worden, Harriet M. Old Mansion Memories. Oneida, NY, 1950. 